


\section{Estimating requirement values for apparent faecal digestible and standardised ileal digestible amino acids in broilers by a meta-analysis approach}


Veldkamp, T., J.W. van Riel, R.A. Dekker, S. Khalaji, V. Khaksar, H. Hashemipour, M.M. van Krimpen, M.C. Blok, 2016. Estimating requirement values for apparent faecal digestible and standardised ileal digestible amino acids in broilers by a meta-analysis approach. Wageningen UR (University \& Research centre) Livestock Research, Livestock Research Report 964.

(C) 2016 Wageningen UR Livestock Research, P.O. Box 338, 6700 AH Wageningen, The Netherlands, T +31 (0) 3174839 53, E info.livestockresearch@wur.nl, www.wageningenUR.nl/en/livestockresearch. Livestock Research is part of Wageningen UR (University \& Research centre).

All rights reserved. No part of this publication may be reproduced and/or made public, whether by print, photocopy, microfilm or any other means, without the prior permission of the publisher or author.

\section{.

The ISO 9001 certification by DNV underscores our quality level. All our research commissions are in line with the Terms and Conditions of the Animal Sciences Group. These are filed with the District Court of Zwolle.

Livestock Research Report 964 - http://dx.doi.org/10.18174/388691 


\section{Table of contents}

$\begin{array}{ll}\text { Preface } & 11\end{array}$

$\begin{array}{ll}\text { Summary } & 12\end{array}$

$\begin{array}{llr}1 & \text { Introduction } & 15\end{array}$

$2 \quad$ Material and Methods $r$

$\begin{array}{lll}2.1 & \text { Database } & 17\end{array}$

2.2 Inclusion criteria for including papers into the database 17

2.3 Calculations 18

2.4 Statistical analysis $\quad 18$

2.4.1 Regression analysis per experiment 18

2.4.2 Overall regression (Regression analysis over experiments) 19

3.1 Lysine background information on meta-analysis 21

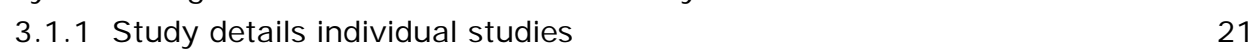

3.1.2 Results of curve fitting and lysine requirements for individual studies 22

3.1.3 Results of overall curve fitting and lysine requirements as a function of age 23

3.1.4 Feed intake affects estimation of lysine intake requirement 23

$\begin{array}{ll}3.2 & \text { Lysine requirement values } \\ \end{array}$

3.2.1 Requirement of AFD lysine expressed on dietary content for body weight gain

3.2.2 Requirement of AFD lysine expressed on dietary content for feed conversion ratio

3.2.3 Requirement of SID lysine expressed on dietary content for body weight gain

3.2.4 Requirement of SID lysine expressed on dietary content for feed conversion ratio

4.1 Methionine+Cysteine background information on meta-analysis

4.1.1 Results of curve fitting and methionine+cysteine requirements for individual studies

4.1.2 Results of overall curve fitting and methionine+cysteine requirements as a function of age

4.2 Methionine+cysteine requirement values

4.2.1 Requirement of AFD methionine+cysteine expressed on dietary content for body weight gain

4.2.2 Requirement of AFD methionine+cysteine expressed on dietary content for feed conversion ratio

4.2.3 Requirement of SID methionine+cysteine expressed on dietary content for body weight gain

4.2.4 Requirement of SID methionine+cysteine expressed on dietary content for feed conversion ratio 
5.1.1 Study details individual studies 33

5.1.2 Results of curve fitting and valine requirements for individual studies 33

5.1.3 Results of overall curve fitting and valine requirements as a function of age 33

5.2 Valine requirement values

5.2.1 Requirement of AFD valine expressed on dietary content for body weight gain

5.2.2 Requirement of AFD valine expressed on dietary content for feed conversion ratio

5.2.3 Requirement of SID valine expressed on dietary content for body weight gain

5.2.4 Requirement of SID valine expressed on dietary content for feed conversion ratio

6.1 Arginine background information on meta-analysis 36

6.1.1 Study details individual studies 36

6.1.2 Results of curve fitting and arginine requirements for individual studies 36

6.1.3 Results of overall curve fitting and arginine requirements as a function of age

7.1 Isoleucine background information on meta-analysis 38

$\begin{array}{lll}7.1 .1 & \text { Study details individual studies } & 38\end{array}$

7.1.2 Results of curve fitting and isoleucine requirements for individual studies 38

7.1.3 Results of overall curve fitting and isoleucine requirements as a function of age

8.1 Threonine background information on meta-analysis 39

8.1.1 Study details individual studies $\quad 39$

8.1.2 Results of curve fitting and threonine requirements for individual studies 40

8.1.3 Results of overall curve fitting and threonine requirements as a function of age

8.2 Threonine requirement values

8.2.1 Requirement of AFD threonine expressed on dietary content for body weight gain

8.2.2 Requirement of AFD threonine expressed on dietary content for feed conversion ratio

8.2.3 Requirement of SID threonine expressed on dietary content for body weight gain

8.2.4 Requirement of SID threonine expressed on dietary content for feed conversion ratio

9.1 Tryptophan background information on meta-analysis 43
9.1.1 Study details individual studies

9.1.2 Results of curve fitting and tryptophan requirements for individual studies43

9.1.3 Results of overall fitting and tryptophan requirements as a function of age44

9.2 Tryptophan requirement values 
9.2.1 Requirement of AFD tryptophan expressed on dietary content for body weight gain

9.2.2 Requirement of AFD tryptophan expressed on dietary content for feed conversion ratio

9.2.3 Requirement of SID tryptophan expressed on dietary content for body weight gain

9.2.4 Requirement of SID tryptophan expressed on dietary content for feed conversion ratio

Requirement values of lysine on AFD and SID basis, expressed as content in the diet, at different ages for BWG and FCR

Requirement values of methionine+cysteine on AFD and SI D basis, expressed as content in the diet at different ages for BWG and FCR

Requirement values of valine on AFD and SID basis, expressed as content in the diet at different ages for BWG and FCR

Requirement values of arginine on AFD and SID basis, expressed as content in the diet, at different ages for BWG and FCR

Requirement values of isoleucine on AFD and SI D basis, expressed as content in the diet, at different ages for BWG and FCR

Requirement values of threonine on AFD and SI D basis, expressed as content in the diet, at different ages for BWG and FCR

Requirement values of tryptophan on AFD and SID basis, expressed as content in the diet, at different ages for BWG and FCR

Appendix 1 Experiments for which the requirement on the AFD and SID Iysine concentration for BWG was estimated according to equation 2 and that also met the criteria for the overall regression to estimate the relationship of the AFD and SI D lysine requirement for BWG with age

Appendix 2 Experiments for which the requirement on the AFD and SI D lysine concentration for FCR was estimated according to equation 2 and that also met the criteria for the overall regression to estimate the relationship of the AFD and SI D lysine requirement for FCR with age62

Appendix 3 Experiments for which the requirement on the AFD and SID methionine+cysteine concentration for BWG was estimated according to equation 2 and that also met the criteria for the overall regression to estimate relationship of the AFD and SI D methionine+cysteine requirement for BWG with age

Appendix 4 Experiments for which the requirement on the AFD and SID methionine+cysteine concentration for FCR was estimated according to equation 2 and that also met the criteria for the overall regression to estimate relationship of the AFD and SID methionine+cystine requirement for FCR with age 
Appendix 5 Experiments for which the requirement on the AFD and SID valine concentration for BWG was estimated according to equation 2 and that also met the criteria for the overall regression to estimate relationship of the AFD and SID valine requirement for BWG with age

Appendix 6 Experiments for which the requirement on the AFD and SI D valine concentration for FCR was estimated according to equation 2 and that also met the criteria for the overall regression to estimate relationship of the AFD and SID valine requirement for FCR with age

Appendix 7 Experiments for which the requirement on the AFD and SID arginine concentration for BWG was estimated according to equation 2 and that also met the criteria for the overall regression to estimate relationship of the AFD and SID arginine requirement for BWG with age

Appendix 8 Experiments for which the requirement on the AFD and SID arginine concentration for FCR was estimated according to equation 2 and that also met the criteria for the overall regression to estimate relationship of the AFD and SID arginine requirement for FCR with age

Appendix 9 Experiments for which the requirement on the AFD and SID isoleucine concentration for BWG was estimated according to equation 2 and that also met the criteria for the overall regression to estimate relationship of the AFD and SID isoleucine requirement for BWG with age

Appendix 10 Experiments for which the requirement on the AFD and SID isoleucine concentration for FCR was estimated according to equation 2 and that also met the criteria for the overall regression to estimate relationship of the AFD and SID isoleucine requirement for FCR with age

Appendix 11 Experiments for which the requirement on the AFD and SID threonine concentration for BWG was estimated according to equation 2 and that also met the criteria for the overall regression to estimate the relationship of the AFD and SID threonine requirement for BWG with age

Appendix 12 Experiments for which the requirement on the AFD and SID threonine concentration for FCR was estimated according to equation 2 and that also met the criteria for the overall regression to estimate the relationship of the AFD and SID threonine requirement for FCR with age

Appendix 13 Experiments for which the requirement on the AFD and SID tryptophan concentration for BWG was estimated according to equation 2 and that also met the criteria for the overall regression to estimate the relationship of the AFD and SID tryptophan requirement for BWG with age

Appendix 14 Experiments for which the requirement on the AFD and SID tryptophan concentration for FCR was estimated according to equation 2 and that also met the criteria for the overall regression to estimate the relationship of the AFD and SID tryptophan requiremet for FCR with age 


\section{Preface}

Diet composition, e.g. concentrations of energy, protein, vitamins and minerals, largely influence the zootechnical performance of poultry. Nowadays, protein requirements are more precisely described in terms of apparent faecal digestible amino acid (AFD) or standardised ileal digestible amino acid (SID) requirement values and amino acid profiles expressing the requirement of each amino acid relative to lysine. Appropriate requirement values for amino acids (AA) in poultry diets are essential for optimizing poultry production and profit of the poultry chain.

CVB, formerly part of the Dutch Product Board Animal Feed (PDV) and now part of the Federatie Nederlandse Diervoedingsketen (FND; Federation Dutch Animal Feed Chain), is responsible for recommending the Dutch poultry chain on AA requirements for various poultry species. The latest public review of AA requirements in poultry in the Netherlands was presented two decades ago (Schutte et al., 1996). As a consequence of several recent developments such as change in genetic predisposition for growth, the increasing trend of formulating low-protein diets and the increasing availability of free AA for supplementation in broilers diets, it was recommended that requirement values for AA in broiler diets should be updated. The present study was subsidized by the (former) Product Board Animal Feed and the (former) Product Board Poultry and Eggs. 


\section{Summary}

Requirement values for apparent faecal digestible and standardised ileal digestible lysine of broilers at different ages were estimated by a meta-analysis approach. This study was part of a project to estimate the apparent faecal (AFD) and standardized ileal digestible (SID) amino acid requirement values of the first limiting amino acids in both broilers and laying hens.

Peer reviewed papers were selected, describing experimental results of dose response studies in which the effect of graded levels of free amino acids supplemented to a basal diet on body weight gain and feed conversion ratio in broilers was studied. The papers searched for were published during the period 1994 2012. Subsequently, a stepwise process was applied for the selection of the research data to be used in the meta-analysis. In total 11 criteria were set. Two of these criteria are: at least three graded levels of supplementation of the amino acid of interest to the same basal diet; maximal supplementation of the amino acid of interest was at least $10 \%$ higher compared to the concentration of the amino acid of interest in the basal (non-supplemented) diet. Feed ingredient composition of the experimental diets should be present in each paper; this information was included in a separate database and nutrient composition of the experimental diets was recalculated by using data on the nutritional composition of the individual feed ingredients according to the CVB Feed Table (2007). When the determined level of the amino acid of interest (and - when presented - of other amino acids) on an AFD basis was published, this information was used. In case this information was not presented, the level of the amino acid of interest (and of other amino acids) was calculated by using either the total amino acid levels in the basal diets as analysed by the authors or as calculated by using the CVB Feed Table (2007) in combination with the digestibility on an AFD basis as published by CVB (CVB Table, 2007) In addition, the concentrations of standardized ileal digestible (SID) amino acids in the diets of each study were also calculated using the digestibility on an SID basis as tabulated by CVB (Dekker and Blok, in press) and were included in the database. These (calculated) dietary concentration of AFD and SID amino acids were used in the present study for the regression analyses to derive requirement values for AFD and SID amino acids in broilers.

The responses of body weight gain (BWG) and feed conversion ratio (FCR) to supplementation of the free amino acid of interest to a basal diet were analysed for each individual experiment included in the database by regression analysis. Mean data for BWG and FCR per experimental group as provided in the original paper were used as response parameters. Response of BWG and FCR to supplementation of the free amino acid of interest was determined by use of an exponential model. For each individual experiment the estimated requirement (Req) for the amino acid of interest was calculated as the amino acid concentration at which $95 \%$ of the response (BWG and FCR) between intercept and asymptotic value was reached. Data of studies that could not be fitted with the exponential model were excluded from further evaluation. Also studies, where the estimated requirement value was over $110 \%$ of the maximum concentration of the amino acid of interest in the diet with the highest supplementation level, were excluded from further evaluation. Studies in which a non-test amino acid might have been colimiting ( $<90 \%$ of CVB 1996) at higher supplementation levels of the amino acid of interest were also excluded from the dataset. After estimation and evaluation of the amino acid requirement values for the individual studies, an overall regression model was used to fit the requirement values of the amino acid of interest on an AFD and SID basis for BWG and FCR as a function of age of the broilers. For this purpose the mean age of broilers in each experiment was calculated as (age at start of the experimental period + age at the end of the experimental period) $/ 2$.

The estimated requirement values for apparent faecal digestible and standardised ileal digestible amino acids for broilers are presented hereafter. 


\section{Lysine}

Requirement values of AFD and SID lysine concentrations in the diet were estimated at different ages. A summary is presented in the Table.

\begin{tabular}{|c|c|c|c|c|c|}
\hline \multirow[t]{2}{*}{ Day } & \multirow{2}{*}{$\begin{array}{l}\text { AFD lysine ( } \% \text { in diet) } \\
\text { CVB (2007) }\end{array}$} & \multicolumn{2}{|c|}{ AFD lysine ( $\%$ in diet) } & \multicolumn{2}{|c|}{ SI D lysine ( $\%$ in diet) } \\
\hline & & $\begin{array}{c}\text { Body weight } \\
\text { gain }\end{array}$ & $\begin{array}{c}\text { Feed conversion } \\
\text { ratio }\end{array}$ & $\begin{array}{l}\text { Body weight } \\
\text { gain }\end{array}$ & $\begin{array}{c}\text { Feed conversion } \\
\text { ratio }\end{array}$ \\
\hline 7 & 1.05 & 1.19 & 1.26 & 1.20 & 1.28 \\
\hline 14 & 1.02 & 1.11 & 1.19 & 1.13 & 1.21 \\
\hline 21 & 1.02 & 1.07 & 1.15 & 1.09 & 1.17 \\
\hline 28 & 0.99 & 1.04 & 1.12 & 1.06 & 1.15 \\
\hline 35 & 0.99 & 1.02 & 1.10 & 1.04 & 1.12 \\
\hline 42 & 0.99 & 1.00 & 1.08 & 1.02 & 1.11 \\
\hline
\end{tabular}

Estimated AFD and SID lysine requirements for BWG are lower than for FCR. Until four weeks of age the AFD and SID lysine requirement for BWG are significantly higher than the CVB (2007) recommendations for AFD lysine requirement. AFD and SID lysine requirement for FCR are over the entire period significantly higher than the CVB (2007) recommendations for AFD lysine requirement.

\section{Methionine+cysteine}

The relation between the methionine+cysteine requirement for BWG and FCR on AFD and on SID basis and age was not significant, which means that this desk study does not result in reliable information to estimate the levels of required methionine+cysteine for broilers at different ages.

\section{Valine}

Requirement values of AFD and SID valine concentrations in the diet were estimated at different ages. A summary is presented in the Table.

\begin{tabular}{cccccc} 
Day & AFD valine $(\%$ in diet) & AFD valine $(\%$ in diet) & SI D valine (\% in diet) \\
& CVB (2007) & $\begin{array}{c}\text { Body weight } \\
\text { gain }\end{array}$ & $\begin{array}{c}\text { Feed } \\
\text { conversion } \\
\text { ratio }\end{array}$ & $\begin{array}{c}\text { Body weight } \\
\text { gain }\end{array}$ & $\begin{array}{c}\text { Feed } \\
\text { conversion } \\
\text { ratio }\end{array}$ \\
\hline 7 & 0.84 & - & 0.97 & - & 0.97 \\
\hline 14 & 0.82 & - & 0.84 & - & 0.85 \\
\hline 21 & 0.82 & - & 0.76 & - & 0.77 \\
\hline 28 & 0.79 & - & 0.70 & - & 0.72 \\
\hline 35 & 0.79 & - & 0.66 & - & 0.68 \\
\hline 42 & 0.79 & - & 0.63 & - & 0.65 \\
\hline
\end{tabular}

The relation between the valine requirement for BWG on AFD and SID basis and age was not significant. The relation between the valine requirement and age for FCR on AFD basis was significant $(P<0.001)$ and also the relation between the valine requirement and age for FCR on SID basis was significant $(P=0.005)$. Until 14 days of age the AFD and SID valine requirement values for FCR are slightly higher than the CVB (1996) recommendations for AFD valine requirement. From 17 days of age AFD and SID valine requirement values for FCR were lower than the CVB (1996) recommendations for AFD valine requirement.

\section{Arginine}

Requirement values of AFD arginine content and SID arginine was not estimated at different ages because the number of studies was too limited to get reliable data from the overall regression analysis. 


\section{I soleucine}

Requirement values of AFD isoleucine content and SID isoleucine content was not estimated at different ages because the number of studies was too limited to get reliable data from the overall regression analysis.

\section{Threonine}

Requirement values of AFD threonine content and SID threonine content were estimated at different ages. A summary is presented in the Table.

\begin{tabular}{|c|c|c|c|c|c|}
\hline \multirow[t]{2}{*}{ Day } & \multirow{2}{*}{$\begin{array}{c}\text { AFD threonine (\% in } \\
\text { diet) } \\
\text { CVB (1996) }\end{array}$} & \multicolumn{2}{|c|}{ AFD threonine ( $\%$ in diet) } & \multicolumn{2}{|c|}{ SID threonine ( $\%$ in diet) } \\
\hline & & Body weight gain & $\begin{array}{c}\text { Feed conversion } \\
\text { ratio }\end{array}$ & Body weight gain & $\begin{array}{c}\text { Feed conversion } \\
\text { ratio }\end{array}$ \\
\hline 7 & 0.68 & 0.66 & - & 0.68 & - \\
\hline 14 & 0.66 & 0.60 & - & 0.61 & - \\
\hline 21 & 0.66 & 0.57 & - & 0.58 & - \\
\hline 28 & 0.64 & 0.54 & - & 0.55 & - \\
\hline 35 & 0.64 & 0.52 & - & 0.53 & - \\
\hline 42 & 0.64 & 0.51 & - & 0.52 & - \\
\hline
\end{tabular}

The relation between the threonine requirement and age for BWG on AFD basis was significant $(P=0.02)$ and also the relation between the threonine requirement and age for BWG on SID basis was significant $(P=0.02)$. The relation between the threonine requirement for FCR on AFD and SID basis and age was not significant. Until 7 days of age the AFD and SID threonine requirement values for BWG were slightly higher than the CVB (1996) recommendations for AFD threonine requirement. After 7 days of age, AFD and SID threonine requirement values for BWG were substantially lower than the CVB (1996) recommendations for AFD threonine requirement.

\section{Tryptophan}

Requirement values of tryptophan on AFD and on SID basis at different ages for BWG and FCR were restricted to the age period of 9.5 to 12.5 days of age. Therefore, it was not possible to estimate the requirement values for the total production period. 


\section{Introduction}

Diet composition, e.g. concentrations of energy, protein, vitamins and minerals, largely influence the zootechnical performance of poultry. Nowadays, protein requirements are more precisely described in terms of digestible amino acid requirements and amino acid profiles expressing the requirement of each amino acid relative to lysine. Appropriate digestible amino acid requirements in poultry diets are essential for optimizing poultry production and profit of the poultry chain.

CVB, formerly part of the Dutch Product Board Animal Feed (PDV) and now part of the Federatie Nederlandse Diervoedingsketen (FND; Federation Dutch Animal Feed Chain), is responsible for advising the Dutch feed industry on nutrient requirements for various poultry species. The latest public review on amino acid requirements in poultry in the Netherlands, however, was conducted two decades ago (CVB, 1996). The requirement values of amino acids (CVB, 1996) were expressed on an apparent faecal digestible (AFD) basis. As a consequence of several recent developments, it was recommended that amino acid requirements should be updated:

- The genetic predisposition for body weight gain of broilers has increased substantially during the last decades;

- $\quad$ The increasing trend of formulating low-protein diets;

- The increasing availability of free amino acids for diet supplementation;

- Different feeding strategies are developed to improve animal welfare and (intestinal) health.

Nutrient requirements have been determined in many experiments. A general method for integrating quantitative knowledge from multiple experiments has been proposed and is referred to as meta-analysis (St-Pierre, 2001). The technique is based on collecting data from multiple published studies that fulfil a number of criteria and formulating a statistical model that best explains the observations (van Houwelingen et al., 2002). Moreover, the meta-analytical approach is highly suited for establishing requirements values because it focuses on estimating on a population level from multiple studies, while accounting for the heterogeneity between studies. The statistical model used in meta-analytical studies should be based on a hierarchical or a mixed model, which has at least two stages (van Houwelingen et al., 2002). The first-stage hierarchy models the within-study variability as a function of the primary covariate (e.g., Lys content). The second-stage hierarchy models the between-study variability through individual random effects and study-related covariates (e.g. strain, gender, year of publication etc.), identifying systematic trends among studies.

Meta-analysis, which combines the results from various experiments at the same time, has more power to detect small differences. For estimating amino acid requirement values by use of a meta-analysis approach, formulating criteria for inclusion or exclusion of studies is very important. The main requirement for a proper meta-analysis is a well-executed systematic review. Therefore in the current work, key journals were searched and reference lists of papers were checked carefully.

The current requirement values for amino acids in broilers (CVB, 1996) are expressed on an apparent faecal digestible (AFD) basis. For the present study it was recommended by CVB to estimate requirement values for amino acids in broilers on a standardized ileal digestible basis. According to Lemme et al. (2004) and Adedokun et al. (2008) standardised ileal amino acid digestibility (SID) coefficients are corrected for the contribution of amino acids of basal endogenous origin to the total ileal digesta pool. Changing the system of expressing amino acid requirement values based on AFD into SID amino acid concentration of dietary ingredients affect the amino acid requirement values of broilers. It is important that amino acid requirement values and the dietary supply of amino acids are expressed identically.

The present study was part of a project conducted to estimate requirement values for the first limiting apparent faecal digestible (AFD) and standardized ileal digestible (SID) amino acids in broilers and laying 
hens at different ages using a meta-analysis approach. In this report the requirement values for lysine, methionine+cysteine, threonine, arginine, tryptophan, valine and isoleucine in broilers are described. For lysine the background information of the meta-analysis is described in detail in this report as an example and to motivate some basal assumptions. For the other essential amino acids involved in this study, details of each study are presented per amino acid in Wageningen Livestock Research reports:

- Wageningen Livestock Research report 965

- Wageningen Livestock Research report 966

- Wageningen Livestock Research report 967

- Wageningen Livestock Research report 968

- Wageningen Livestock Research report 969

- Wageningen Livestock Research report 970

- Wageningen Livestock Research report 971 lysine

methionine+cysteine

threonine

arginine

tryptophan

valine

isoleucine 


\section{Material and Methods}

\section{$2.1 \quad$ Database}

Peer reviewed papers were selected, describing experimental results of dose response studies in which the effect of graded levels of free amino acids supplemented to a basal diet on body weight gain and feed conversion ratio in broilers was studied. The papers were searched by using the key words 'broiler' and 'name of relevant amino acid' in the electronic database 'Web of Science'. The papers searched for were published during the period 1994 - 2012. Relevant search results were found in Asian-Australian Journal of Animal Science, Italian J ournal of Animal Science, Journal of Applied Poultry Research, Journal of Animal and Veterinary Advances Poultry Science, Poultry Science and Revista Brasileira de Zootecnia. A stepwise process was applied for the selection of research data to be used.

\subsection{Inclusion criteria for including papers into the database}

The studies were reviewed according to the following inclusion criteria:

1. The experimental procedure should be adequately provided, meaning a clear description of the experimental units, the number of broilers per unit, the age of the broilers and the duration of the experiment;

2. Provision of information on the broilers used (strain, age);

3. Provision of information on the (metabolizable) energy content of the diets (for adult cockerels);

4. Provision of information on how amino acid levels in the basal diet(s) in the paper are expressed (total, faecal, ileal, on an apparent or standardized basis);

5. Only dose response studies were included in which besides a basal level of the amino acid of interest at least three graded levels of supplementation of the amino acid of interest to the same basal diet were tested;

6. Only dose response studies were included in which the maximal supplementation of the amino acid of interest was at least $10 \%$ higher compared to the concentration of the amino acid of interest in the basal (non-supplemented) diet;

7. With the exception of the concentration of the amino acid of interest (that should be - far - below the CVB requirement), the concentration of the following amino acids in the basal diet should be at least $90 \%$ of the CVB (1996) requirement (on AFD basis) for methionine+cysteine, threonine and tryptophan. For isoleucine, arginine and valine the concentration in the basal diet should be at least $85 \%$ of the CVB (1996) requirement (on AFD basis), because the requirements of these amino acids were documented less accurately;

8. Experimental diets should be adequately described in terms of ingredient composition and should contain analysed or calculated contents for at least crude protein and essential amino acids;

9. Feed intake levels of experimental groups (receiving the diets with supplemented free amino acid) within the same experiment should be less than $150 \%$ relative to the feed intake level of the group fed the basal, non-supplemented basal diet;

10. Provision of data on feed intake, BWG and FCR in dose response studies with broilers in which the effects of increasing levels of the dietary amino acid of interest was evaluated by supplementing a basal diet with different levels of the free amino acid of interest;

11. Supplementation of the free amino acid of interest to the basal diet should have a statistical significant effect on BWG and/or FCR according to the original author. 
Information of the papers that met these inclusion criteria was included in a database. Besides the information on the inclusion criteria as mentioned above, additional information from the study (if available) was added also to the database (e.g. strain, sex, etc.). Further, the amino acid requirement value as derived by the original author(s) of the study was included in the database as well and also the statistical method to estimate the amino acid requirement under study was included. Studies not meeting the inclusion criteria as mentioned above, were excluded from the database.

\subsection{Calculations}

Feed ingredients in the basal diet composition used in each experiment of studies that met the criteria in Paragraph 2.2 were included in a separate database. Subsequently, nutrient composition of these experimental diets was recalculated by using data on the nutritional composition of the individual feed ingredients according to the CVB Feed Table (2007). Regarding the levels of digestible amino acids the following procedure was used:

a. When the paper presents the level of lysine in the basal diets expressed on a (apparent faecal) digestible basis, it was decided to use this figure. As far as the levels of one or more other amino acids (see criterion 7 for the other amino acids that were considered to be relevant), were also expressed on this basis, this information was used in the further processing of the study. For those amino acids for which this information was lacking, the level of digestible amino acid was calculated according to option b. or c.;

b. When no information was presented in the paper on the level of (apparent) faecal digestible lysine and/or other amino acids, the next option was to use the total level of lysine and/or of the other amino acids as analysed in the basal diets. Using the faecal amino acid digestibility of the feed ingredients in the CVB Feed Table (2007), the faecal digestibility of the amino acids in the basal diet and, subsequently, the level of apparent faecal digestible amino acids was calculated;

c. When no information as described in the options a. and b. was available, the total levels of the amino acids needed were calculated using the ingredient composition of the experimental diets (see criterion 8) as presented in the paper. In these cases the starting point was the ingredient composition (Weende analysis, ME value and amino acid pattern) as published in the CVB Feed Table 2007. To reproduce satisfactory the level of crude protein and - when given - the metabolizable energy level as given in the paper, in a number of cases (slight) adjustment of the protein level and - as a consequence - the amino acid levels of - preferably - the protein rich ingredients was necessary. Subsequently, the digestible amino acid levels on an AFD basis were calculated using the digestibility in the CVB Feed Table (2007).

In addition, the concentrations of standardized ileal digestible (SID) amino acids in the basal diets of each study were also calculated using option b. or c. and were included in the database. The standardized ileal amino acid digestibility coefficients of feed ingredients required for the calculation of SID amino acid contents were derived from Dekker and Blok (in press).

The supplemented free amino acids were considered to be $100 \%$ digestible, both on an AFD and SID basis.

The calculated dietary concentrations of AFD and of SID amino acids were used in the present study for the regression analyses to derive requirement values for amino acids on an AFD and SID basis for Body Weight Gain (BWG) and Feed Conversion Ratio (FCR) in broilers.

\subsection{Statistical analysis}

\subsubsection{Regression analysis per experiment}

The responses of BWG and FCR to supplementation of the free amino acid of interest to a basal diet were analysed by regression analysis. Mean data for BWG and FCR per experimental group as provided in the original paper were used as response parameters. 
The response of BWG and FCR to supplementation of free amino acid of interest was determined by use of an exponential model as is described by the following mathematical equation:

$\mathrm{Y}_{\mathrm{ij}}=\mathrm{a}_{\mathrm{i}}+\mathrm{b}_{\mathrm{i}} *\left(1-\mathrm{e}^{(-\mathrm{Ci} * \mathrm{dx})}\right)+\underline{\varepsilon i j} \mathbf{( 1 )}$

Where: $Y_{i j}=$ response value of BWG or FCR for experiment $\mathrm{i}$ and treatment $\mathrm{j}$;

$\mathrm{a}_{\mathrm{i}} \quad=$ estimated basal level (for $\mathrm{dx}=0$ ) of the amino acid of interest for experiment $\mathrm{i}$;

$\mathrm{b}_{\mathrm{i}} \quad=$ difference between basal level and estimated asymptotic level for BWG and FCR response for experiment i;

$\mathrm{C}_{\mathrm{i}} \quad=$ rate parameter (for speed of curving) for experiment $\mathrm{i}$;

$\mathrm{dx}=$ difference in amino acid concentration of interest (AFD or SID based) compared to basal (non-supplemented diet) in experiment $i$; $\left(X_{i}-\operatorname{MIN}\left(X_{i}\right)\right) ; X_{i}=$ amino acid concentration of interest in experimental diets, $\mathrm{MIN}\left(\mathrm{X}_{\mathrm{i}}\right)=$ amino acid concentration of interest in basal (non-supplemented) diet;

$\varepsilon i j=$ error $\mathrm{ij}$.

For each individual experiment the estimated requirement (Req) for the amino acid of interest was calculated as the amino acid concentration where $95 \%$ of the response (BWG and FCR) between intercept and asymptotic value was reached. The estimated amino acid requirement was calculated by the following mathematical equation:

$\operatorname{Req}_{i}=\frac{\ln (0.05)}{-C i}+\mathrm{MIN}(\mathrm{Xi}) \quad(\mathbf{2})$

Where: Req $_{\mathrm{i}}=$ Estimated amino acid requirement (\%) of the individual experiment $\mathrm{i}$;

$\operatorname{Ln}(0.05)=\operatorname{elog}(0.05)$;

$\mathrm{C}_{\mathrm{i}} \quad=$ rate parameter (for speed of curving) for experiment $\mathrm{i}$;

$\operatorname{MIN}\left(X_{i}\right)=$ amino acid $(\%)$ in basal (non-supplemented) diet.

\subsubsection{Overall regression (Regression analysis over experiments)}

After estimation of the amino acid requirement values for individual studies by using the exponential model according to equation 2, the amino acid requirement as a function of age was studied.

However, before doing this the results from the previous step were evaluated according to the following criteria:

- Mean age of the animals.

The mean age of broilers was determined in each experiment as (days of age at start of the experimental period + days of age at the end of the experimental period)/2. Experiments in which the mean age was $>42$ days were excluded from the database for the overall regression.

- Calculated requirement (as the AFD or SID amino acid level at which $95 \%$ of the plateau level was reached) was compared to the highest dietary amino acid level in the experiment.

When the calculated requirement was $>110 \%$ of the amino acid level in the treatment with the highest supplemented amino acid level, the study was excluded from the database for the overall regression

- Lack of fit.

Studies in which no requirement could be estimated according to equation 2 were excluded from the database for the overall regression. 
- Co-limitation of other amino acids

In the first review (see paragraph 2.2, criterion 7) only studies were included in the database if, besides the concentration of the amino acid of interest, the concentration of several other essential amino acids in the basal diet was at least $90 \%$ or $85 \%$ (depending on the amino acid) of the requirement (on AFD basis) according to CVB (1996). In this second review it was evaluated if the ratios of these amino acids relative to the amino acid of interest on an AFD basis were at least 0.90 of the ratio of the requirement of the same amino acids on an AFD basis according to CVB (1996). In formula:

(level non test amino acid $X$ basal diet in study $y_{i} /\left(\right.$ calculated requirement test amino acid in study $\left.\mathrm{y}_{\mathrm{i}}\right) \geq$ $0.90 *$ (requirement non test amino acid X, CVB 1996)/( requirement test amino acid, CVB 1996).

The regression model for the requirement of SID amino acid content and AFD amino acid content is described by the following mathematical equation:

$\operatorname{Req}_{i}=ß_{0}+ß_{1} * \ln \left(A g e_{i}\right)+\underline{\varepsilon i}(3)$

Where: $\operatorname{Req}_{\mathrm{i}} \quad=$ amino acid requirement (content ( $\%$ in diet))

$B_{0}=$ estimated amino acid requirement at hatch

$B_{1} \quad=$ estimated linear effect of $\ln ($ Age $)$

$\ln \left(\mathrm{Age}_{\mathrm{i}}\right)=\mathrm{e} \log ($ Age $\mathrm{i})$

Age $\quad=$ average age of broilers in experiment $(\mathrm{d})$

Selection of candidate models with more factors included such as strain, gender, year, length of the experimental period, was not possible because of the restricted number of experiments that were accepted for overall regression analysis. 


\section{Lysine requirement values}

\subsection{Lysine background information on meta-analysis}

\subsubsection{Study details individual studies}

In total, 26 studies each containing one or more experiments, were judged. Table 1 provides an overview of the 28 experiments from 11 papers that met the criteria described in Paragraph 2.2 for inclusion into the database. The procedure used to calculate the level of apparent faecal digestible lysine (see Par. 2.3) is also mentioned. The number of lysine supplementation levels per experiment ranged from 4 to 10 . The data in the database covered various age periods of birds. In 15 experiments males were used, in 11 experiments females were used and in 2 experiments broilers were as hatched (mixed). Different strains were used in the experiments. 


\section{Table 1}

List of references that met the inclusion criteria for further evaluation of the lysine requirement of broilers in the present study.

\begin{tabular}{|c|c|c|c|c|c|c|}
\hline $\begin{array}{l}\text { Experiment } \\
\text { number }\end{array}$ & Reference & $\begin{array}{l}\text { Nr. of } \\
\text { dose } \\
\text { levels }\end{array}$ & $\begin{array}{l}\text { Range of } \\
\text { AFD Lys } \\
\text { content } \\
\text { (g/ kg) }\end{array}$ & $\begin{array}{l}\text { Age of } \\
\text { broilers } \\
\text { (d) }\end{array}$ & Gender & Strain \\
\hline $11^{\text {a) }}$ & Mahdavi et al. (2012) & 6 & 7.7-11.2 & $35-49$ & male & - \\
\hline $12^{\text {a) }}$ & Mahdavi et al. (2012) & 6 & 7.7-11.2 & $35-49$ & female & - \\
\hline $21^{\text {a) }}$ & Garcia et al. (2006) & 5 & $7.0-11.0$ & $7-21$ & male & Cobb \\
\hline $22^{\text {a) }}$ & Garcia et al. (2006) & 4 & $7.0-10.0$ & $7-21$ & male & Cobb \\
\hline $23^{\text {a) }}$ & Garcia et al. (2006) & 5 & $7.0-11.0$ & $7-21$ & female & Cobb \\
\hline $24^{\text {a) }}$ & Garcia et al. (2006) & 4 & $7.0-10.0$ & $7-21$ & female & Cobb \\
\hline $25^{\text {a) }}$ & Garcia et al. (2006) & 5 & $8.0-11.2$ & $7-21$ & male & Cobb \\
\hline $26^{\text {a) }}$ & Garcia et al. (2006) & 5 & $8.0-11.2$ & $7-21$ & male & Cobb \\
\hline $27^{\text {a) }}$ & Garcia et al. (2006) & 5 & $8.0-11.2$ & $7-21$ & female & Cobb \\
\hline $28^{\text {a) }}$ & Garcia et al. (2006) & 5 & $8.0-11.2$ & $7-21$ & female & Cobb \\
\hline $31^{\text {a) }}$ & Dozier et al. (2009) & 6 & $9.0-12.5$ & 14-28 & male & Ross \\
\hline $41^{\text {a) }}$ & Dozier et al. (2009) & 9 & $8.5-12.5$ & $14-28$ & male & Ross \\
\hline $42^{\text {a) }}$ & Dozier et al. (2009) & 9 & $8.5-12.5$ & $14-28$ & female & Ross \\
\hline $51^{\text {a) }}$ & Dozier and Payne exp. 1 (2012) & 7 & $9.2-13.9$ & 7-15 & female & Ross \\
\hline $52^{\text {a) }}$ & Dozier and Payne exp. 2 (2012) & 7 & $9.1-14.0$ & 7-15 & female & HubbardxCobb \\
\hline $53^{\text {a) }}$ & Dozier and Payne exp. 1 (2012) & 7 & $9.2-13.9$ & $1-7$ & female & Ross \\
\hline $54^{\text {a) }}$ & Dozier and Payne exp. 2 (2012) & 7 & $9.1-14.0$ & $1-7$ & female & HubbardxCobb \\
\hline $81^{c)}$ & Mehri et al. (2010) & 6 & $6.2-12.2$ & $15-28$ & mixed & Ross \\
\hline $111^{\text {a) }}$ & Aftab et al. (2007) exp. 1 & 5 & $7.2-9.7$ & $4-21$ & mixed & Hubbard \\
\hline $121^{b)}$ & Fatufe et al. (2004) & 10 & $3.1-15.3$ & $8-21$ & male & Ross \\
\hline $131^{\text {a) }}$ & Berri et al. (2008) & 4 & $8.3-11.3$ & $21-42$ & male & Ross \\
\hline $132^{\text {a) }}$ & Berri et al. (2008) & 4 & $8.3-11.3$ & $21-42$ & male & Ross \\
\hline $141^{\text {a) }}$ & Dozier et al. (2010) & 9 & $6.4-12.0$ & $28-42$ & male & Ross \\
\hline $142^{\text {a) }}$ & Dozier et al. (2010) & 9 & $6.4-12.0$ & $28-42$ & male & Cobb \\
\hline $151^{\text {a) }}$ & Mack et al (1999) & 6 & $6.6-11.1$ & $20-40$ & male & Ross \\
\hline $152^{\text {a) }}$ & Mack et al (1999) & 6 & $6.6-11.1$ & $20-40$ & male & ISA \\
\hline $210^{\text {a) }}$ & Garcia et al. (2006) & 5 & $8.9-12.1$ & $7-21$ & male & Cobb \\
\hline $212^{\text {a) }}$ & Garcia et al. (2006) & 5 & $8.9-12.1$ & $7-21$ & female & Cobb \\
\hline
\end{tabular}

a) Digestible Lys level (on AFD basis) in basal diet analysed by authors and used in present study.

b) Total Lys level in basal diet analysed by authors and used in present study; calculation of digestible Lys level (on AFD basis) in basal diet was done by using these data in combination with the AFD coefficients in the CVB Feed Table (2007).

c) Total Lys level calculated using the ingredient composition as published and the amino acid profile of CVB Feed Table (2007); calculation of digestible Lys level (on AFD basis) was done as described in ${ }^{\text {b). }}$

\subsubsection{Results of curve fitting and lysine requirements for individual studies}

In general, the response of BWG and FCR to AFD and SID lysine content in the experimental diet showed an exponential relationship, when using as input the mean data for BWG and FCR per experimental group as provided in the original paper. The response of BWG and FCR to graded supplementation levels of dietary lysine was determined for all individual experiments according to the exponential model (1) described in paragraph 2.4.1. 
The requirement for AFD and SID lysine was determined for each study and defined as the dietary lysine concentration at which $95 \%$ of the response (difference between performance at no additional lysine supplementation and the performance at the asymptotic value) was met according to equation (2) in the paragraph 2.4.1.

The estimation of AFD and SID lysine requirement of experiment 21 is presented in Table 2.

\section{Table 2}

Estimation of requirement of AFD and SID lysine content (\% in diet) based on 95\% of the response for body weight gain and feed conversion ratio of experiment number 21 (in brackets the by the author presented AFD lysine requirement)

\begin{tabular}{lcc} 
Response parameter & AFD lysine & SI D lysine \\
& $\%$ & 1.13 \\
\hline Body weight gain & $1.11(0.96)$ & 1.02 \\
\hline Feed conversion ratio & $1.01(0.96)$ & 1.02 \\
\hline
\end{tabular}

In experiment number 21 the author derived an AFD requirement at the dietary lysine concentration at which $90 \%$ of the response (difference between performance at no additional lysine supplementation and the performance at the asymptotic value) was met. Therefore the requirement as presented by the author of the study including experiment number 21 is lower than the requirement as determined by the calculation in the present report which was based on the dietary lysine content at which $95 \%$ of the response (difference between performance at no additional lysine supplementation and the performance at the asymptotic value) was reached.

\subsubsection{Results of overall curve fitting and lysine requirements as a function of age}

For estimating the AFD and SID lysine requirement as a function of age, an overall regression analysis was conducted on AFD and SID lysine requirement values derived from the individual experiments and the mean age in these experiments according to the general model (3) described in paragraph 2.4.2. An overview of experiments that were included in the overall regression analysis of the experiments is presented in Appendix 1 and 2. Details of the individual experiments and estimated AFD lysine requirement and SID lysine requirement for BWG and FCR are presented in these appendixes as well. The results of the overall fitting are presented in Paragraph 3.2.

\subsubsection{Feed intake affects estimation of lysine intake requirement}

Experiments with very high responses of feed intake ( $>150 \%$ relative to basal diet) to increased dietary lysine contents in the experiment were excluded according to inclusion criteria.

In all studies included in the database, feed intake of broilers fed the basal diets was significantly lower than feed intake of broilers fed lysine supplemented diets. As an example, data from experiment 11 (Mahdavi et al. (2012) were taken to demonstrate the effect of supplementation of dietary lysine on the response of feed intake.

In Figure 1 the response in daily feed intake was plotted against relative increased (in percentage) lysine concentration. It appears that feed intake increased rapidly at the first steps of supplementation of lysine. The response of feed intake to supplementation of lysine stabilized at $+8.2 \%$ relative to the feed intake of broilers receiving the basal diet. 


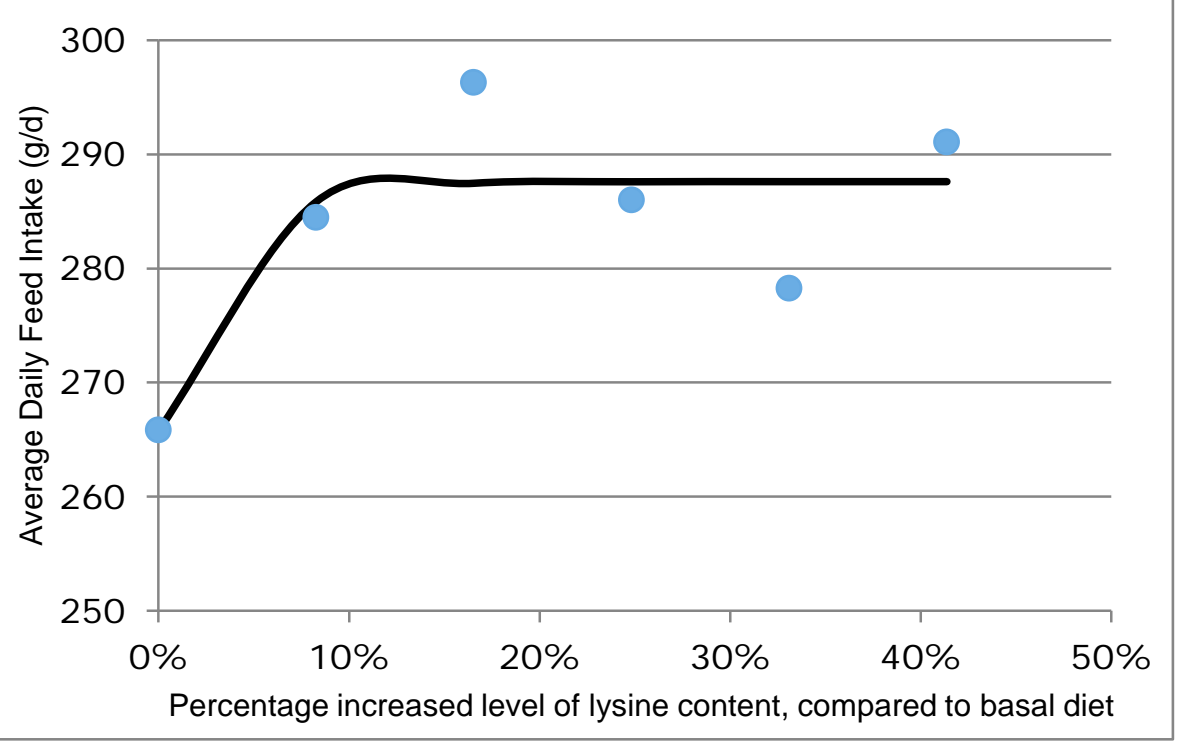

Figure 1 Response of daily feed intake $(\mathrm{g} / \mathrm{d})$ as function of lysine content relative to basal lysine content of experiment 11 (Mahdavi et al., 2012) (R-square $=47 \%$; $B_{\text {-parameter }}=21.8(+8.2 \%)$ ).

From Figure 1 it can be concluded that dietary lysine concentration affects feed intake.

The slope of response curve as a function of daily lysine intake is more straight/flat compared to the response curve as a function of lysine content. This is illustrated in Figure 2 and 3

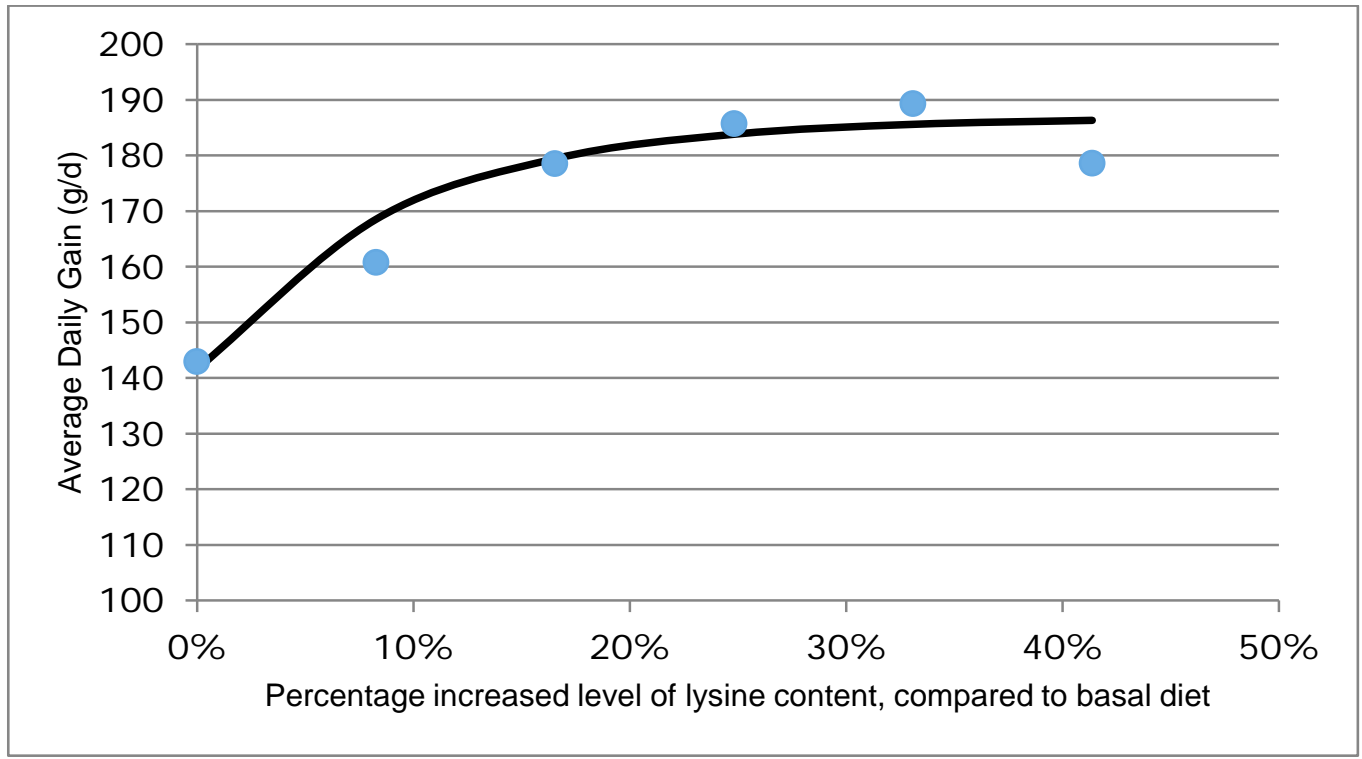

Figure 2 Response of body weight gain $(\mathrm{g} / \mathrm{d})$ as function of lysine content relative relative to basal lysine content of experiment 11 (Mahdavi et al., 2012) (R-square $=87 \%$; C-parameter $=0.090$; Requirement $=133 \%$ of lowest lysine content level.

In Figure 2 the response of body weight gain was plotted against relative increased (in percentage) lysine content. The calculated lysine requirement was $+33 \%$ compared to the dietary lysine content in the basal diet. This was still inside the range of the lysine content (treatment) levels of the experiment (no extrapolation). On this basis the results of the experiment would be included in the further evaluation for obtaining lysine requirement values. 
In Figure 3 the response of average daily gain was plotted against relative increased (in percentage) lysine intake.

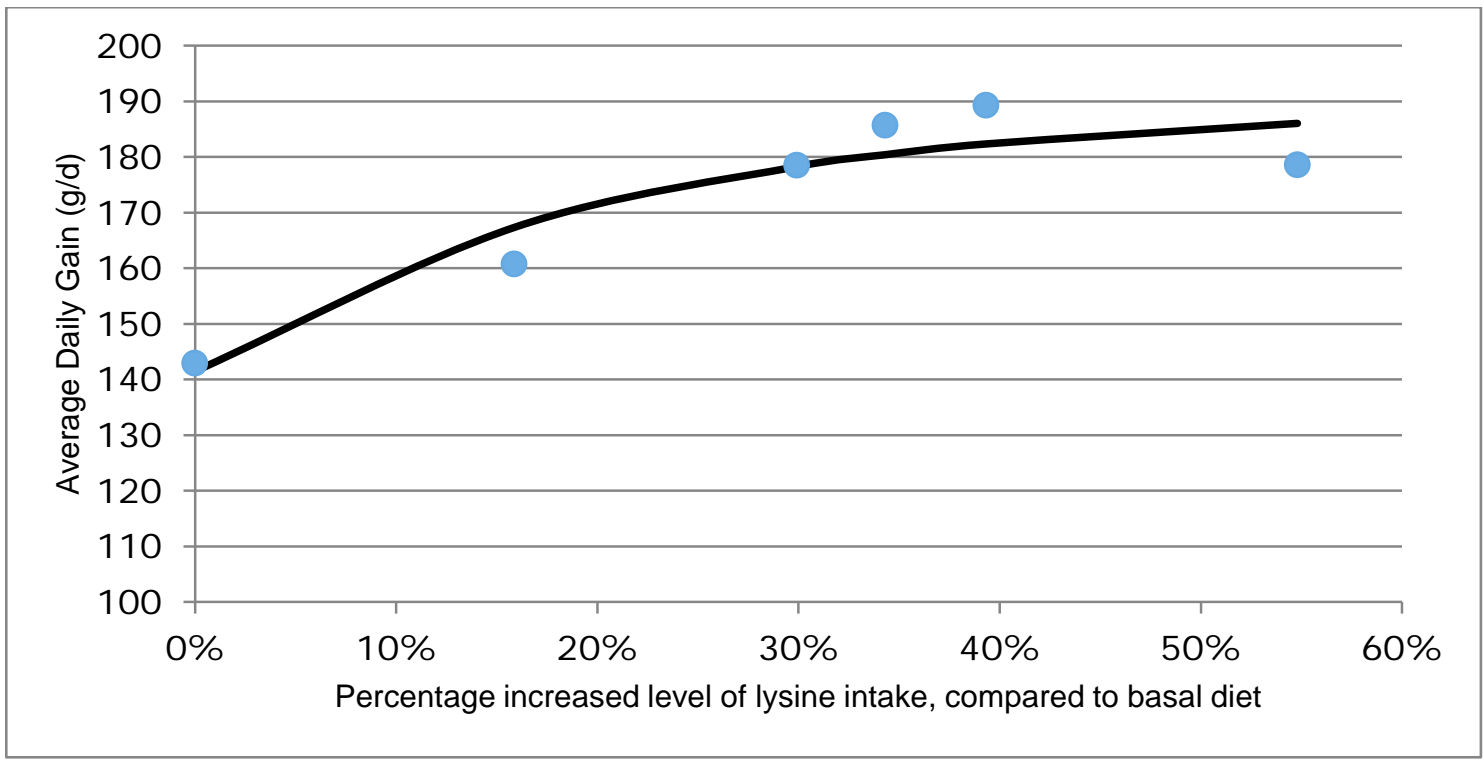

Figure 3 Response in body weight gain $(\mathrm{g} / \mathrm{d})$ as function of lysine intake relative to relative to basal lysine content of experiment 11 (Mahdavi et al., 2012) (R-square $=81 \%$; $C_{\text {-parameter }}=0.049$; Requirement $=161 \%$ of lowest lysine intake level.

Due to straightening of the curve (because of increased feed intake) the estimated requirement of lysine intake was $+61 \%$ (much higher) to the dietary lysine content in the basal diet, which was also outside the range of treatment levels for lysine intake. For the latter reason this experiment was excluded from the dataset for the final analysis for estimation of the requirement of lysine intake. By expressing the requirement of lysine on a daily intake basis the requirement values are likely to be overestimated for body weight gain as well as feed conversion ratio.

It can be concluded that the requirement for dietary lysine intake will be overestimated when feed intake is affected by supplementation of L-lysine in dose-response studies. The curve will be more flat and the requirement at $95 \%$ of the response will be higher in this case. Therefore it should be considered to determine requirement values for lysine only on a concentration basis (lysine content in the diet). Also for other essential amino acids involved in this study amino acid requirement values are based on amino acid content.

For estimating the SID and AFD lysine requirement values an overall regression analysis was conducted on SID and AFD lysine requirement derived from the individual experiments according to the general model (3) in the paragraph 2.4 'Statistical analysis'. In the overall regression model the parameter age was included.

\subsection{Lysine requirement values}

In paragraph 3.2.1 up to paragraph 3.2.4 the results of the overall regression analysis on requirement values derived from individual experiments are presented in graphs. Lysine requirement values in these paragraphs are expressed on AFD or SID lysine content in the diet and are expressed for BWG as well as FCR. 


\subsubsection{Requirement of AFD lysine expressed on dietary content for body weight gain}

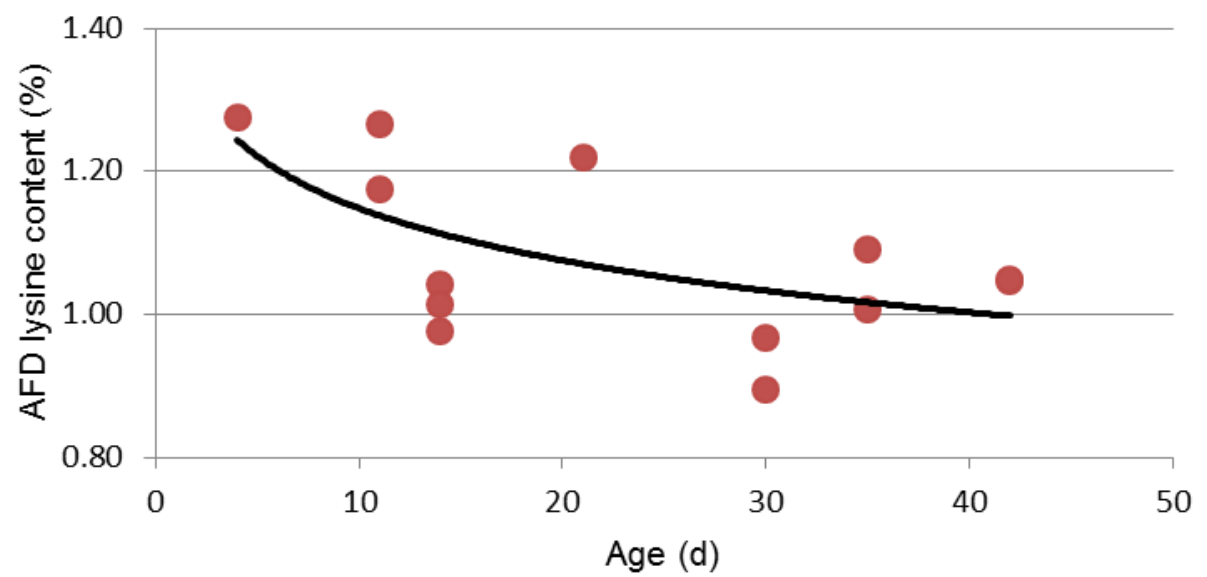

Figure 4 Requirement of AFD lysine content (\% in diet) for body weight gain at different ages (based on Exp.no. 11, 12, 22, 28, 212, 41, 51, 52, 54, 141, 142, 151, 152). The point at day 42 covers the results of two experiments.

The fitted requirement of AFD lysine, expressed as a percentage of diet, for BWG was based on thirteen experiments.

3.2.2 Requirement of AFD lysine expressed on dietary content for feed conversion ratio

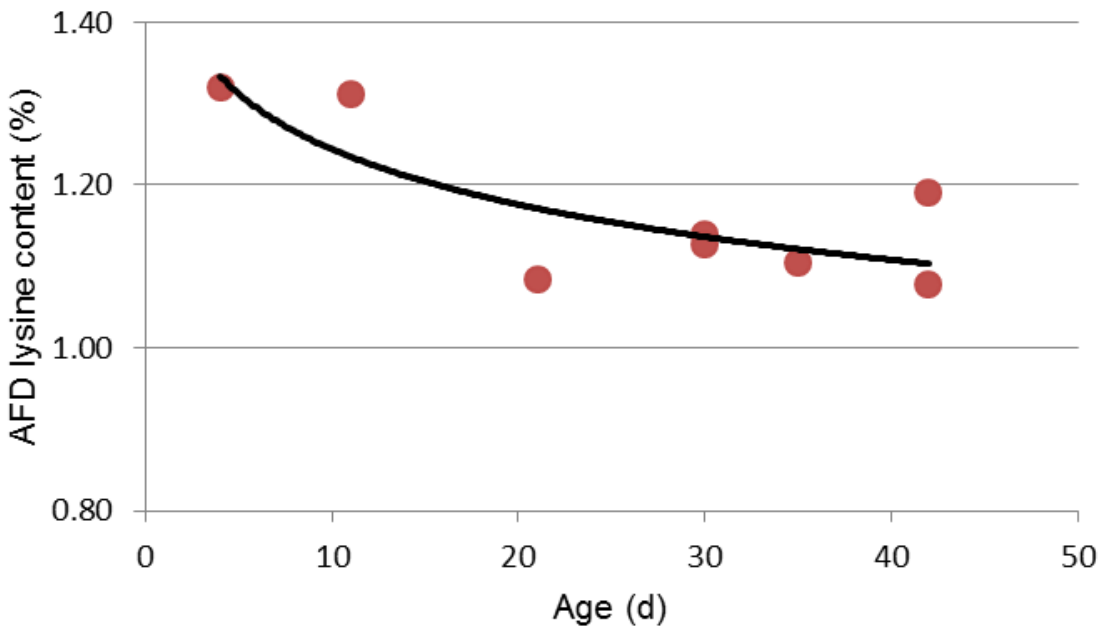

Figure 5 Requirement of AFD lysine content (\% in diet) for feed conversion ratio at different ages (based on Exp.no.11, 12, 42, 52, 54, 142, 151 and 152). The point at day 30 covers the results of two experiments. 
The fitted requirement of AFD lysine content expressed as a percentage of diet for FCR at different ages was based on eight experiments.

3.2.3 Requirement of SID lysine expressed on dietary content for body weight gain

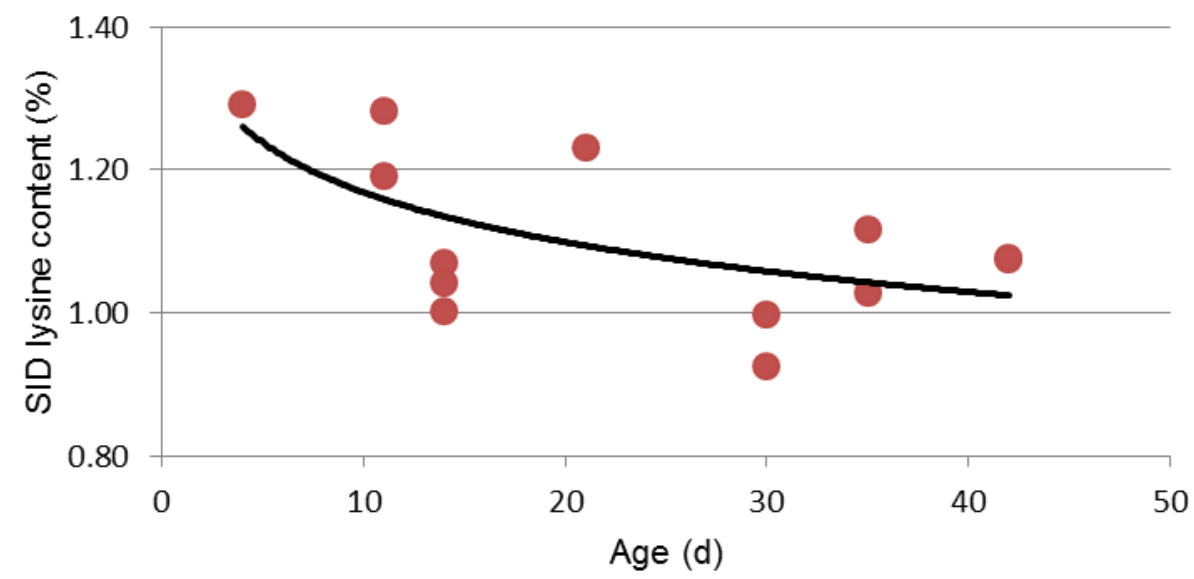

Figure 6 Requirement of SID lysine content (\% in diet) for body weight gain at different ages (based on Exp.no. 11, 12, 22, 28, 212, 41, 51, 52, 54, 141, 142, 151 and 152). The points at day 42 covers the results of two experiments.

The fitted requirement of SID lysine content, expressed as a percentage of diet for BWG at different ages was based on thirteen experiments.

\subsubsection{Requirement of SID lysine expressed on dietary content for feed conversion} ratio

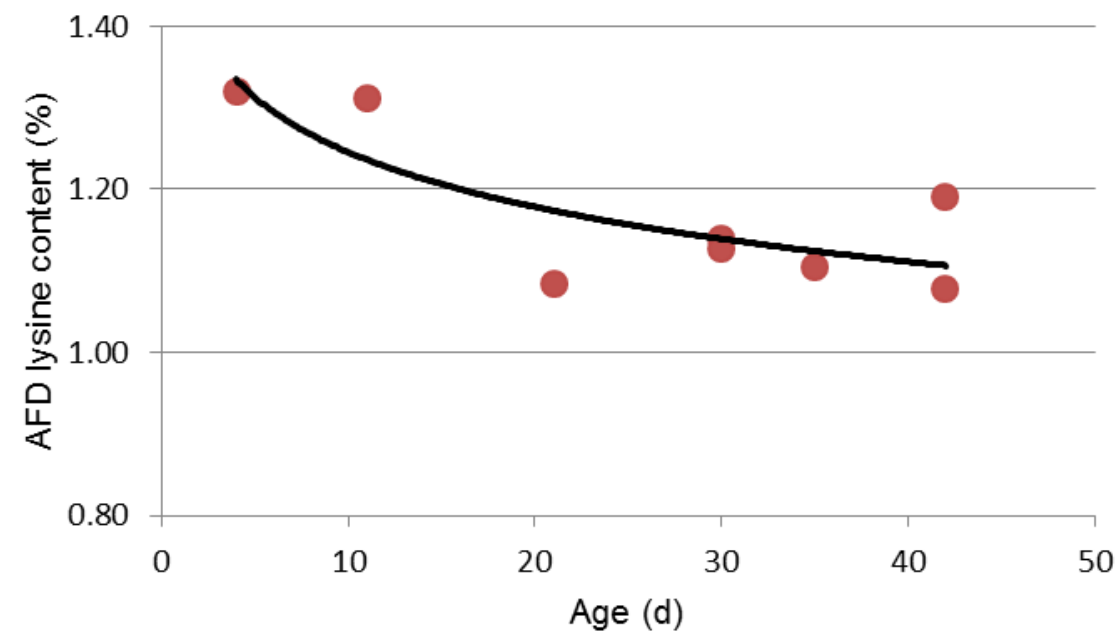

Figure 7 Requirement of SID lysine content (\% in diet) for feed conversion ratio at different ages (based on Exp.no 11, 12, 42, 52, 54, 142, 151 and 152). The point at day 30 covers the results of two experiments.

The fitted requirement of SID lysine content for FCR expressed as a percentage of diet at different ages was based on eight experiments. 


\section{Methionine+Cysteine requirement values}

\subsection{Methionine+Cysteine background information on meta- analysis}

In total, 17 studies each containing one or more experiments, were judged. Table 3 provides an overview of the 32 experiments from 9 papers that met the criteria described in Paragraph 2.2 for inclusion into the database. The procedure used to calculate the level of apparent faecal digestible methionine+cysteine (see Par. 2.3) is also mentioned. The number of methionine+cysteine supplementation levels per experiment ranged from 4 to 8 . The data in the database covered various age periods of birds. In 19 experiments males were used, in 9 experiments females were used and in 4 experiments broilers were as hatched (mixed). Different strains were used in the experiments. 


\section{Table 3}

List of references that met the inclusion criteria for further evaluation of the methionine+cysteine requirement of broilers in the present study.

\begin{tabular}{|c|c|c|c|c|c|c|}
\hline $\begin{array}{l}\text { Experiment } \\
\text { number }\end{array}$ & Reference & $\begin{array}{c}\text { Nr. } \\
\text { of } \\
\text { dose } \\
\text { level } \\
\text { s }\end{array}$ & $\begin{array}{c}\text { Range of AFD } \\
\text { Met+Cys } \\
\text { content ( g/ kg) }\end{array}$ & $\begin{array}{l}\text { Age of } \\
\text { broile } \\
\text { rs (d) }\end{array}$ & Gender & Strain \\
\hline $31^{b)}$ & Chamruspollert et al. 2002 & 5 & $6.2-9.2$ & $7-14$ & Male & Ross \\
\hline $42^{\text {a) }}$ & Castro Goulart et al. 2011 & 6 & $6.0-9.0$ & $8-21$ & Male & Cobb \\
\hline $43^{\text {a) }}$ & Castro Goulart et al. 2011 & 6 & $5.6-8.6$ & $22-35$ & Male & Cobb \\
\hline $44^{\text {a) }}$ & Castro Goulart et al. 2011 & 6 & $5.2-8.2$ & $36-42$ & Male & Cobb \\
\hline $51^{\text {a) }}$ & Mack et al. 1999 & 5 & $5.0-8.0$ & $20-40$ & Male & Ross 208 \\
\hline $61^{\text {a) }}$ & Lumpkins et al. 2007 & 5 & $5.4-9.4$ & $8-16$ & Male & Cobb 500 \\
\hline $62^{\text {a) }}$ & Lumpkins et al. 2007 & 5 & $5.4-9.4$ & $8-16$ & Female & Cobb 500 \\
\hline $65^{\text {a) }}$ & Lumpkins et al. 2007 & 5 & $4.9-8.9$ & $8-19$ & Male & Cobb 500 \\
\hline $66^{\text {a) }}$ & Lumpkins et al. 2007 & 5 & $4.9-8.9$ & 8-19 & Female & Cobb 500 \\
\hline $67^{\text {a) }}$ & Lumpkins et al. 2007 & 5 & $4.9-8.9$ & 8-19 & Male & Cobb 500 \\
\hline $68^{\text {a) }}$ & Lumpkins et al. 2007 & 5 & $4.9-8.9$ & 8-19 & Female & Cobb 500 \\
\hline $69^{\text {a) }}$ & Lumpkins et al. 2007 & 5 & $4.3-8.3$ & $21-42$ & Male & Cobb 500 \\
\hline $610^{\text {a) }}$ & Lumpkins et al. 2007 & 5 & $4.3-8.3$ & $21-42$ & Female & Cobb 500 \\
\hline $71^{b)}$ & Fatufe and Rodehutscord 2005 & 8 & $3.3-9.3$ & $8-21$ & Male & Ross \\
\hline $72^{b)}$ & Fatufe and Rodehutscord 2005 & 8 & $3.4-9.4$ & $8-21$ & Male & Ross \\
\hline $81^{b)}$ & Chamruspollert et al. 2004 & 6 & $7.0-10.0$ & $7-21$ & Male+Female & Ross 208 \\
\hline $82^{b)}$ & Chamruspollert et al. 2004 & 6 & $7.0-10.0$ & $7-21$ & Male+Female & Ross 208 \\
\hline $83^{b)}$ & Chamruspollert et al. 2004 & 6 & $7.0-10.0$ & $7-21$ & Male+Female & Ross 208 \\
\hline $84^{b)}$ & Chamruspollert et al. 2004 & 6 & $7.0-10.0$ & $7-21$ & Male+Female & Ross 208 \\
\hline $92^{\text {b) }}$ & Kalinowski et al. 2003 & 4 & $6.4-8.2$ & $21-42$ & Male & Ross $\times 3 F 8$ \\
\hline $131^{b)}$ & Albino et al.1999 & 6 & $5.8-8.8$ & $1-21$ & Male & Hubbard \\
\hline $132^{b)}$ & Albino et al.1999 & 6 & $5.8-8.8$ & $1-21$ & Female & Hubbard \\
\hline $133^{b)}$ & Albino et al.1999 & 6 & $5.8-8.8$ & $1-21$ & Male & Ross \\
\hline $134^{b)}$ & Albino et al.1999 & 6 & $5.8-8.8$ & $1-21$ & Female & Ross \\
\hline $135^{b)}$ & Albino et al.1999 & 6 & $5.4-8.4$ & $22-42$ & Male & Hubbard \\
\hline $136^{b)}$ & Albino et al.1999 & 6 & $5.4-8.4$ & $22-42$ & Female & Hubbard \\
\hline $137^{\mathrm{b})}$ & Albino et al.1999 & 6 & $5.4-8.4$ & $22-42$ & Male & Ross \\
\hline $138^{b)}$ & Albino et al.1999 & 6 & $5.4-8.4$ & $22-42$ & Female & Ross \\
\hline $141^{b)}$ & Baker et al. 1996 & 6 & $4.0-5.5$ & $28-38$ & Male & RossxHubbard \\
\hline $142^{b)}$ & Baker et al. 1996 & 6 & $4.0-7.0$ & $21-42$ & Male & RossxHubbard \\
\hline
\end{tabular}

\subsubsection{Results of curve fitting and methionine+cysteine requirements for individual studies}

In general, the response of BWG and FCR to AFD and SID methionine+cysteine content in the experimental diet showed an exponential relationship, when using as input the mean data for BWG and FCR per experimental group as provided in the original paper. The response of BWG and FCR to graded supplementation levels of dietary methionine+cysteine was determined for all individual experiments according to the exponential model (1) described in paragraph 2.4.1. 
The requirement for AFD and SID methionine+cysteine was determined for each study and defined as the dietary methionine+cysteine concentration at which $95 \%$ of the response (difference between performance at no additional methionine+cysteine supplementation and the performance at the asymptotic value) was met according to equation (2) in the paragraph 2.4.1.

\subsubsection{Results of overall curve fitting and methionine+cysteine requirements as a function of age}

For estimating the AFD and SID methionine+cysteine requirement as a function of age an overall regression analysis was conducted on AFD and SID methionine+cysteine requirement values derived from the individual experiments and the mean age in these experiments according to the general model (3) described in paragraph 2.4.2.

An overview of experiments that were included in the overall regression analysis of the experiments is presented in Appendix 3 and 4. Details of the individual experiments and estimated AFD methionine+cysteine requirement and SID methionine+cysteine requirement for BWG and FCR are presented in these appendixes as well.

\subsection{Methionine+cysteine requirement values}

In paragraph 4.2.1 up to paragraph 4.2.4 the results of the overall regression analyses on requirement values derived from individual experiments are presented in graphs. Methionine+cysteine requirement values in these paragraphs are expressed on AFD or SID methionine+cysteine content in the diet and are expressed for BWG as well as FCR.

\subsubsection{Requirement of AFD methionine+cysteine expressed on dietary content for} body weight gain

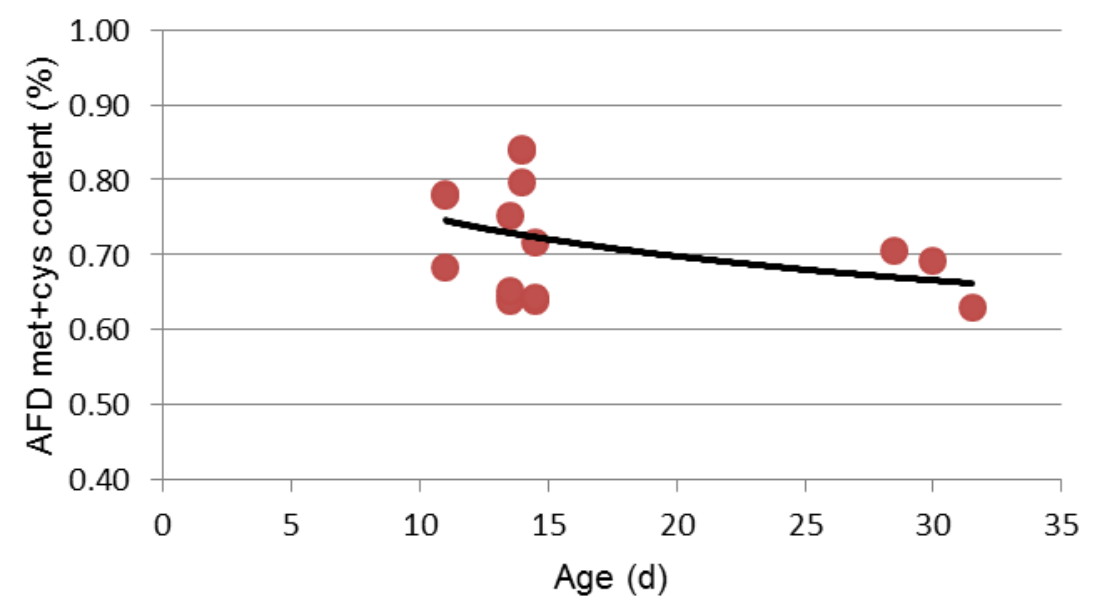

Figure 8 Requirement of AFD methionine+cysteine content ( $\%$ in diet) for body weight gain at different ages (based on Exp.no. 32, 43, 51, 65, 66, 67, 68, 71, 72, 82, 83, 84, 131, 132, 133, 134 and 142). The points at day $11,13.5,14$ and 14.5 covers the results of two experiments.

The fitted requirement of AFD methionine+cysteine for BWG expressed as a percentage of diet at different ages was based on 17 experiments. The mean ages in the different experiments were not well distributed over the entire production period. The variation in methionine+cysteine requirement values, especially at young ages, was large. The relation between the methionine+cysteine requirement and age for BWG on AFD basis was not significant. 


\subsubsection{Requirement of AFD methionine+cysteine expressed on dietary content for feed conversion ratio}

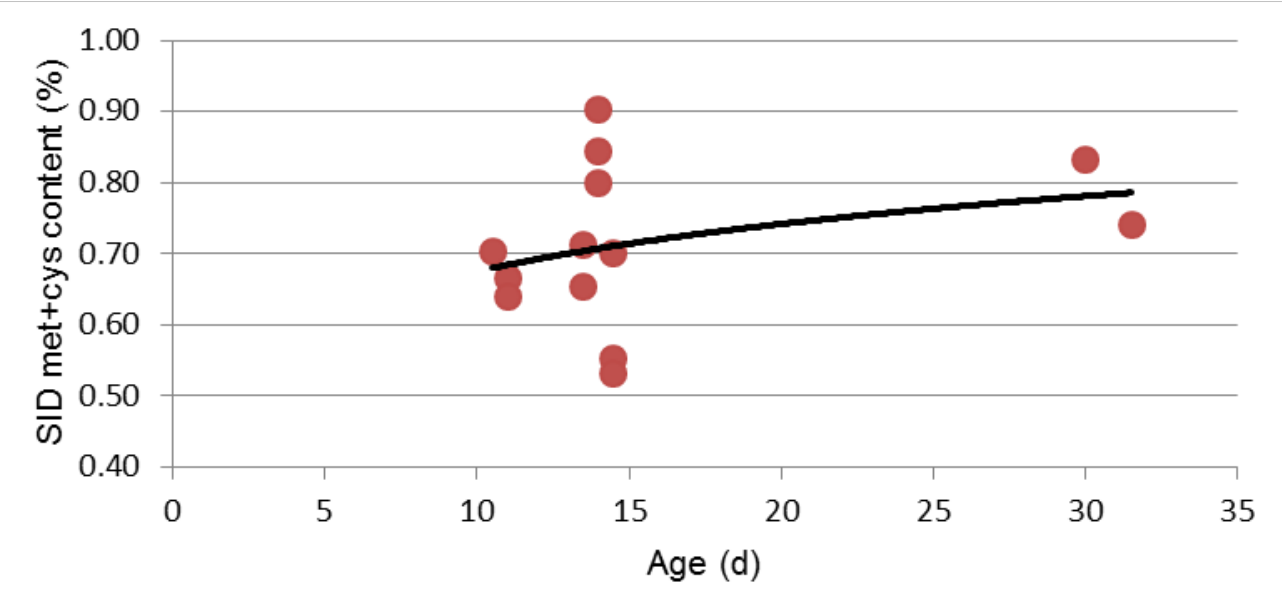

Figure 9 Requirement of AFD methionine+cysteine content ( $\%$ in diet) for feed conversion ratio at different ages (based on Exp.no. 32, 51, 65, 66, 71, 72, 81, 83, 84, 131, 133, 134 and 142).

The fitted requirement of AFD methionine+cysteine content expressed as a percentage of diet for FCR at different ages was based on 13 experiments. Only for one individual experiment an AFD requirement value at older age was available. The mean ages in the different experiments were not well distributed over the entire production period. The variation in methionine+cysteine requirement values, especially at young ages, was large. The relation between the methionine+cysteine requirement and age for FCR on AFD basis was not significant. Further, the relation obtained suggests that the methionine+cysteine requirement increases with age, which cannot be explained physiologically.

\subsubsection{Requirement of SID methionine+cysteine expressed on dietary content for} body weight gain

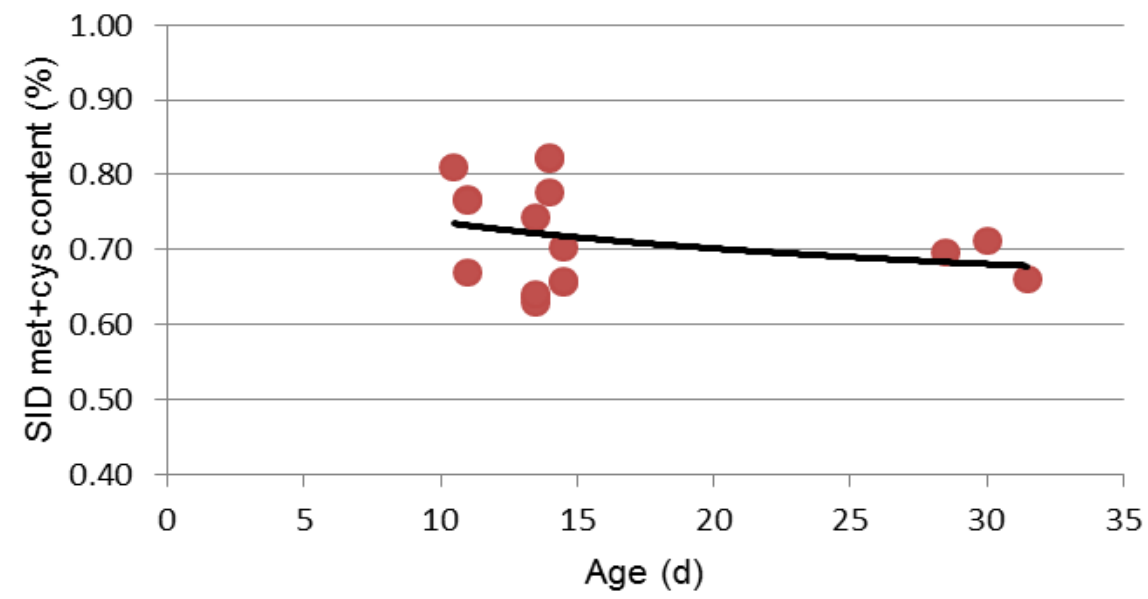

Figure 10 Requirement of SID methionine+cysteine content (\% in diet) for body weight gain at different ages (based on Exp.no.32, 43, 51, 65, 66, 67, 68, 71, 72, 82, 83, 84, 131, 132, 133, 134 and 142). The points at day $11,13.5,14$ and 14.5 covers the results of two experiments.

The fitted requirement of SID methionine+cysteine content expressed as a percentage of diet for BWG at different ages was based on 17 experiments. The mean ages in the different experiments were not well distributed over the entire production period. The variation in methionine+cysteine requirement values, especially at young ages, was large. The relation between the methionine+cysteine requirement and age for BWG on SID basis was not significant. 


\subsubsection{Requirement of SID methionine+cysteine expressed on dietary content for feed conversion ratio}

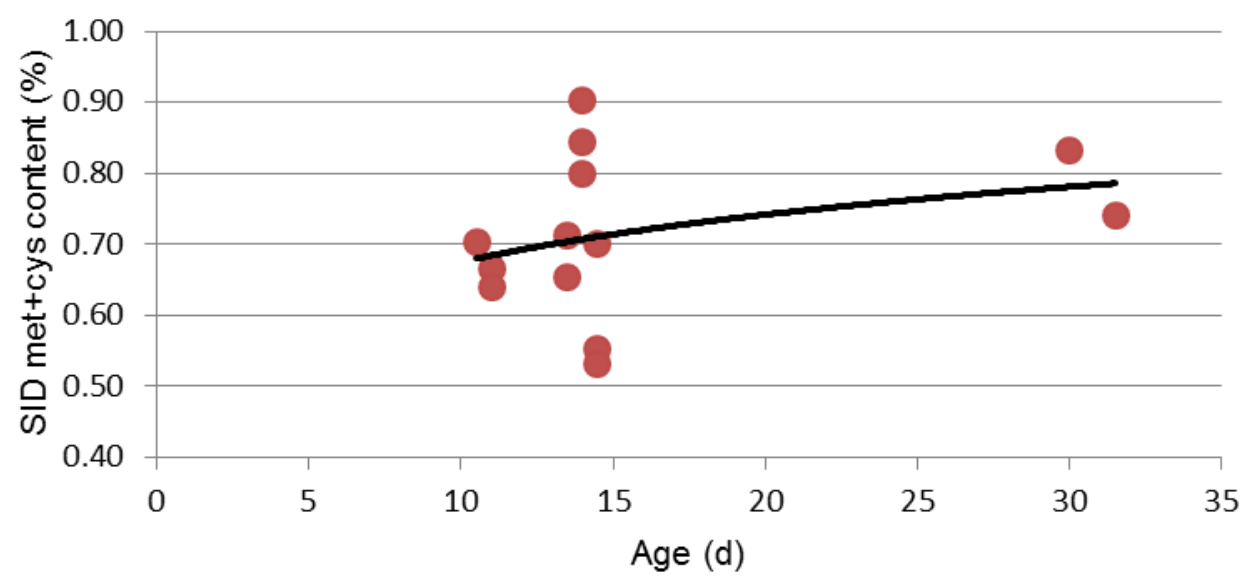

Figure 11 Requirement of SID methionine+cysteine content (\% in diet) for feed conversion ratio at different ages (based on Exp.no. 32, 51, 65, 66, 71, 72, 81, 83, 84, 131, 133, 134 and 142).

The fitted requirement of SID methionine+cysteine content for FCR expressed as a percentage of diet at different ages was based on 13 experiments. The mean ages in the different studies were not well distributed over the entire production period. The variation in methionine+cysteine requirement values, especially at young ages, was large. Only for two individual experiments SID requirement values at older ages were available. The relation between the methionine+cysteine requirement and age for FCR on SID basis was not significant. Further, the relation obtained suggests that the methionine+cysteine requirement increases with age, which cannot be explained physiologically. 


\section{Valine requirement values}

\subsubsection{Study details individual studies}

In total, 12 studies each containing one or more experiments, were judged. Table 4 provides an overview of the 4 experiments from 2 papers that met the criteria for inclusion into the database. The procedure used to calculate the level of apparent faecal digestible valine (see Par. 2.3) is also mentioned. The number of valine supplementation levels per experiment was 6 . The data in the database covered various age periods of birds. In these 4 experiments males were used. Different strains were used in the experiments. In 3 experiments Ross 308 broilers were used and in 1 experiment ISA 220.

\section{Table 4}

List of references that met the inclusion criteria for further evaluation of the valine requirement of broilers in the present study.

\begin{tabular}{|c|c|c|c|c|c|c|}
\hline $\begin{array}{l}\text { Experiment } \\
\text { number }\end{array}$ & Reference & $\begin{array}{c}\text { Nr. of dose } \\
\text { levels }\end{array}$ & $\begin{array}{l}\text { Range of } \\
\text { AFD Val } \\
\text { content } \\
(\mathrm{g} / \mathrm{kg})\end{array}$ & $\begin{array}{c}\text { Age of } \\
\text { broilers (d) }\end{array}$ & Gender & Strain \\
\hline $41^{\text {b) }}$ & Corzo et al. 2008 & 6 & $0.64-1.04$ & $1-14$ & Male & Ross 308 \\
\hline $42^{b)}$ & Corzo et al. 2008 & 6 & $0.62-0.97$ & $14-28$ & Male & Ross 308 \\
\hline $43^{b)}$ & Corzo et al. 2008 & 6 & $0.54-0.89$ & $28-42$ & Male & Ross 308 \\
\hline $71^{\mathrm{a})}$ & Mack et al. 1999 & 6 & $0.56-0.83$ & $20-40$ & Male & ISA 220 \\
\hline
\end{tabular}

a) Digestible Val level (on AFD basis) in basal diet analysed by authors and used in present study.

b) Total Val level in basal diet analysed by authors and used in present study; calculation of digestible Lys level (on AFD basis) in basal diet was done by using these data in combination with the AFD coefficients in the CVB Feed Table (2007).

\subsubsection{Results of curve fitting and valine requirements for individual studies}

In general, the response of BWG and FCR to AFD and SID valine content in the experimental diet showed an exponential relationship, when using as input data the mean data for BWG and FCR per experimental group as provided in the original paper. The response of BWG and FCR to graded supplementation levels of dietary valine was determined for all individual experiments according to exponential model (1) described in paragraph 2.4.1.

The requirement for AFD and SID valine was determined for each study and defined as the dietary valine concentration at which $95 \%$ of the response (difference between performance at no additional valine supplementation and the performance at the asymptotic value) was met according to model (2) described in the paragraph 2.4.1.

\subsubsection{Results of overall curve fitting and valine requirements as a function of age}

For estimating the AFD and SID valine requirement as a function of age, an overall regression analysis was conducted on AFD and SID valine requirement values derived from the individual experiments and the mean age in these experiments according to the general model (3) described in paragraph 2.4.2. An overview of experiments that were included in the overall regression analysis of the experiments is presented in Appendix 5 and 6. Details of the individual experiments and estimated AFD valine requirement and SID valine requirement for BWG and FCR are presented in these appendixes as well. 


\subsection{Valine requirement values}

In paragraph 5.2.1 up to paragraph 5.2.4 the results of the overall regression analyses on requirement values derived from individual experiments are presented in graphs. Valine requirement values in these paragraphs are expressed on AFD or SID content in the diet and are expressed for BWG as well as FCR.

5.2.1 Requirement of AFD valine expressed on dietary content for body weight gain

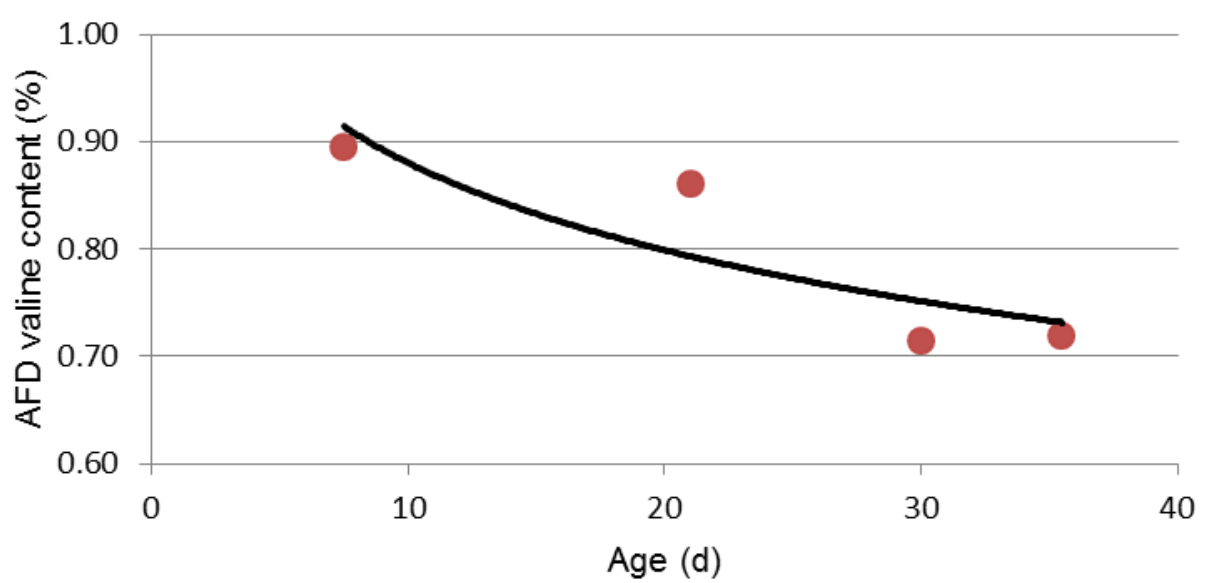

Figure 12 Requirement of AFD valine content (\% in diet) for body weight gain at different ages (based on Exp.no 41, 42, 43, and 71).

The fitted requirement of AFD valine expressed as a percentage of diet for BWG at different ages was based only on four experiments. The relation between the valine requirement and age for BWG on AFD basis was not significant.

5.2.2 Requirement of AFD valine expressed on dietary content for feed conversion ratio

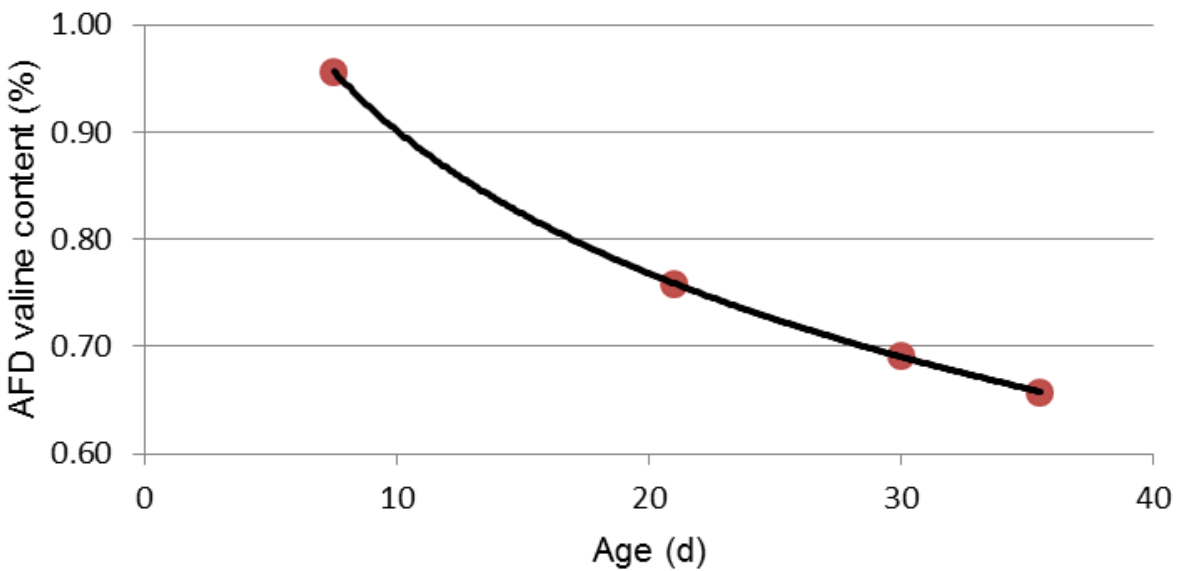

Figure 13 Requirement of AFD valine content (\% in diet) for feed conversion ratio at different ages (based on Exp.no 41, 42, 43 and 71).

The fitted requirement of AFD valine content expressed as a percentage of diet for FCR at different ages was based only on four experiments. The relation between the valine requirement and age for FCR on 
AFD basis was significant $(P<0.001)$. Although the fit for AFD valine requirement values is nice, it is difficult to derive accurate requirement values for AFD valine for FCR based on these four experiments.

\subsubsection{Requirement of SID valine expressed on dietary content for body weight gain}

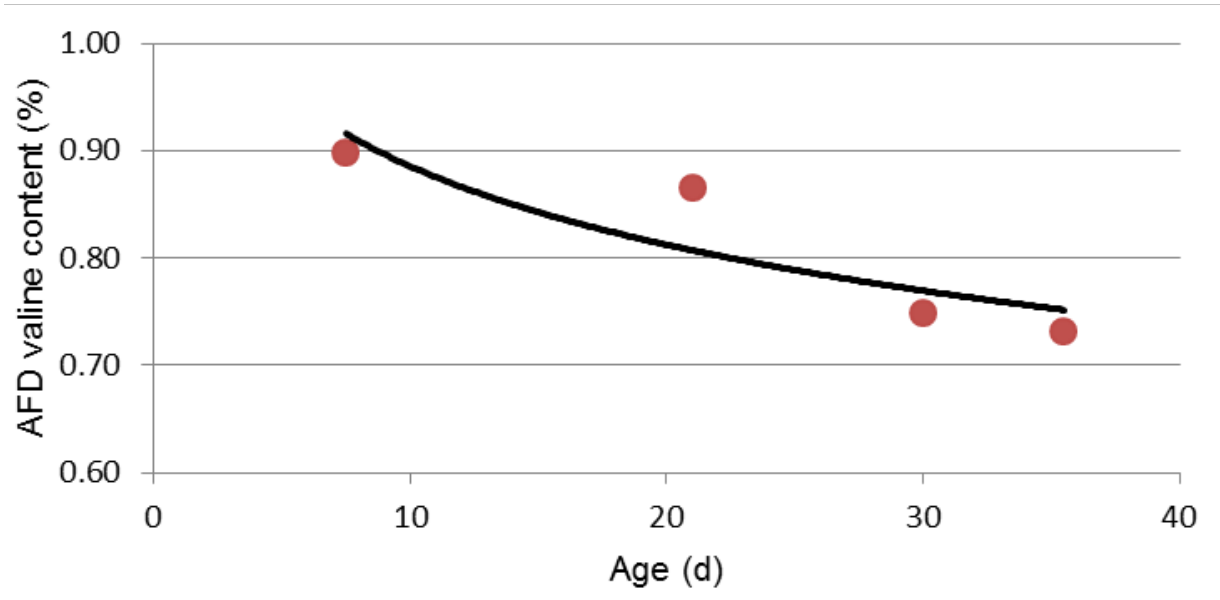

Figure 14 Requirement of SID valine content (\% in diet) for body weight gain at different ages (based on Exp.no 41, 42, 43 and 71).

The fitted requirement of SID valine content expressed as a percentage of diet for BWG at different ages was based only on four experiments. The relation between the valine requirement and age for BWG on SID basis was not significant.

\subsubsection{Requirement of SID valine expressed on dietary content for feed conversion ratio}

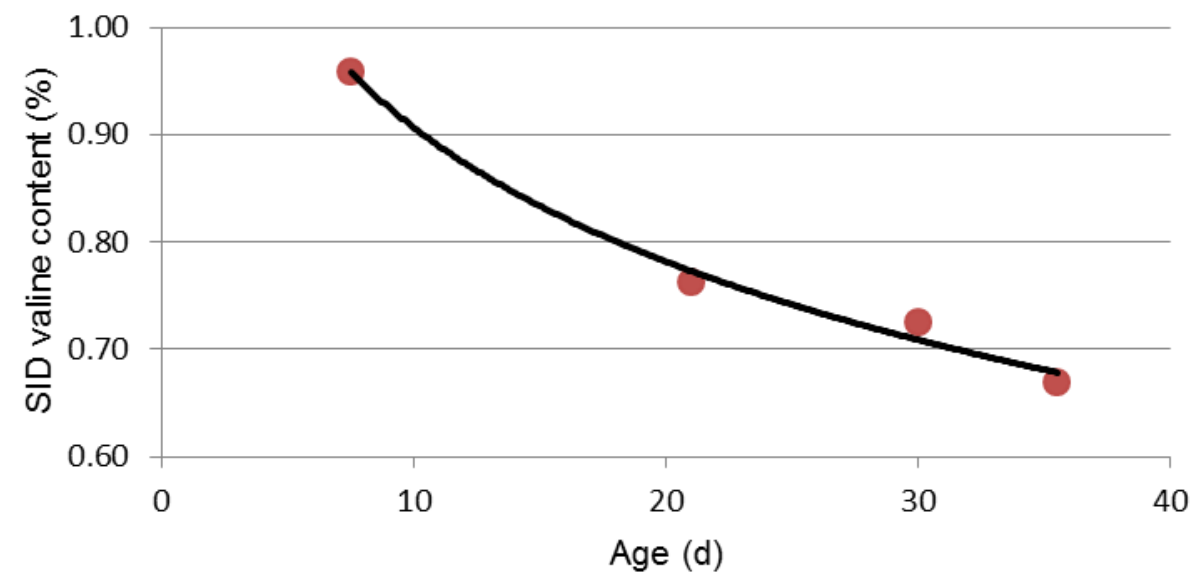

Figure 15 Requirement of SID valine content (\% in diet) for feed conversion ratio at different ages (based on Exp.no 41, 42, 43 and 71).

The fitted requirement of SID valine content expressed as a percentage of diet for FCR at different ages was based only on four experiments. The relation between the valine requirement and age for FCR on SID basis was significant $(P=0.005)$. Although the fit for SID valine requirement values is nice, it is difficult to derive accurate requirement values for SID valine for FCR based on these four experiments. 


\section{Arginine requirement values}

\subsection{Arginine background information on meta-analysis}

\subsubsection{Study details individual studies}

In total, 19 studies each containing one or more experiments, were judged. Table 5 provides an overview of the 5 experiments from 3 papers that met the criteria described in Paragraph 2.2 for inclusion into the database. The procedure used to calculate the level of apparent faecal digestible arginine (see Par. 2.3) is also mentioned. The number of arginine supplementation levels per experiment were 6 or 7 . The data in the database covered various age periods of birds. In all 5 experiments males were used. Different strains were used in the experiments.

\section{Table 5}

List of references that met the inclusion criteria for further evaluation of the arginine requirement of broilers in the present study.

\begin{tabular}{|c|c|c|c|c|c|c|}
\hline $\begin{array}{l}\text { Experiment } \\
\text { Number }\end{array}$ & Reference & $\begin{array}{l}\text { Nr. of } \\
\text { dose } \\
\text { levels }\end{array}$ & $\begin{array}{c}\text { Range of AFD } \\
\text { Arg content } \\
(\mathrm{g} / \mathrm{kg})\end{array}$ & $\begin{array}{l}\text { Age of } \\
\text { broilers } \\
\text { (d) }\end{array}$ & Gender & Strain \\
\hline $81^{\text {b) }}$ & Chamruspollert et al. 2004 & 6 & $8.5-13.5$ & $7-21$ & Male & Ross \\
\hline $82^{b)}$ & Chamruspollert et al. 2004 & 6 & $8.5-13.5$ & $7-21$ & Male & Ross \\
\hline $111^{a)}$ & Labadan et al. 2001 & 7 & 8.8-13.2 & $0-14$ & Male & Ross $\times$ Avian \\
\hline $112^{a)}$ & Labadan et al. 2001 & 6 & 8.8-12.8 & $15-28$ & Male & Ross $\times$ Avian \\
\hline $121^{\text {a) }}$ & Mack et al. 1999 & 6 & $8.0-12.6$ & $20-40$ & Male & Ross 208 \\
\hline
\end{tabular}

a) Digestible Arg level (on AFD basis) in basal diet analysed by authors and used in present study.

b) Total Arg level in basal diet analysed by authors and used in present study; calculation of digestible Arg level (on AFD basis) in basal diet was done by using these data in combination with the AFD coefficients in the CVB Feed Table (2007).

\subsubsection{Results of curve fitting and arginine requirements for individual studies}

In general, the response of BWG and FCR to AFD and SID arginine content in the experimental diet showed an exponential relationship, when using as input data the mean data for BWG and FCR per experimental group as provided in the original paper. The response of BWG and FCR to graded supplementation levels of dietary arginine was determined for all individual experiments according to the exponential model (1) described in paragraph 2.4.1.

The requirement for AFD and SID arginine was determined for each study and defined as the dietary arginine concentration at which $95 \%$ of the response (difference between performance at no additional arginine supplementation and the performance at the asymptotic value) was met according to equation (2) in the paragraph 2.4.1.

\subsubsection{Results of overall curve fitting and arginine requirements as a function of age}

For some experiments it was not possible to fit an exponential curve through the response data (lack of fit) and for some experiments the derived arginine requirement was $>110 \%$ of highest inclusion level of test amino acid as evaluated in the experiments. So, these experiments could not be included in the regression analysis over experiments (according to model (3) described in paragraph 2.4 'Statistical analyses'). The implication of the fact that several studies had to be excluded from the overall analysis was that the number of studies remaining was too limited to get reliable data from the overall analysis. 
An overview of experiments that were included in the overall regression analysis of the experiments is presented in Appendix 7 and 8. Details of the individual experiments and estimated AFD arginine requirement and SID arginine requirement for BWG and FCR are presented in these appendixes as well. 


\section{Isoleucine requirement values}

\subsection{Isoleucine background information on meta-analysis}

\subsubsection{Study details individual studies}

In total, 11 studies each containing one or more experiments, were judged. Table 6 provides an overview of the 4 experiments from 3 papers that met the criteria described in Paragraph 2.2 for inclusion into the database. The procedure used to calculate the level of apparent faecal digestible isoleucine (see Par. 2.3) is also mentioned. The number of isoleucine supplementation levels per experiment were 6 or 7 . The data in the database covered various age periods of birds. In all experiments males were used. Different strains were used in the experiments.

\section{Table 6}

List of references that met the inclusion criteria for further evaluation of the isoleucine requirement of broilers in the present study.

\begin{tabular}{llcccccc}
$\begin{array}{l}\text { Experiment } \\
\text { number }\end{array}$ & Reference & $\begin{array}{c}\text { Nr. of } \\
\text { dose } \\
\text { levels }\end{array}$ & $\begin{array}{c}\text { Range of AFD Ile } \\
\text { content }(\mathbf{g} / \mathbf{k g})\end{array}$ & $\begin{array}{c}\text { Age of } \\
\text { broilers } \\
\text { (d) }\end{array}$ & Gender & Strain \\
$11^{\text {a) }}$ & Tavernari et al. 2012 & 6 & $0.58-0.76$ & $7-21$ & Male & Cobb 500 \\
\hline $12^{\text {a) }}$ & Tavernari et al. 2012 & 6 & $0.53-0.71$ & $30-43$ & Male & Cobb 500 \\
\hline $21^{\text {a) }}$ & Mejia et al. 2011 & 7 & $0.55-0.71$ & $28-42$ & Male & Ross 708 \\
\hline $51^{\text {a) }}$ & Mack et al. 1999 & 6 & $0.51-0.75$ & $20-40$ & Male & ISA \\
\hline
\end{tabular}

a) Digestible ILE level (on AFD basis) in basal diet analysed by authors and used in present study.

\subsubsection{Results of curve fitting and isoleucine requirements for individual studies}

In general, the response of BWG and FCR to AFD and SID isoleucine content in the experimental diet showed an exponential relationship, when using as input data the mean data for BWG and FCR per experimental group as provided in the original paper. The response of BWG and FCR to graded supplementation levels of dietary isoleucine was determined for all individual experiments according to the exponential model (1) described in paragraph 2.4.1.

The requirement for AFD and SID isoleucine was determined for each study and defined as the dietary isoleucine concentration at which $95 \%$ of the response (difference between performance at no additional isoleucine supplementation and the performance at the asymptotic value) was met according to equation (2) in the paragraph 2.4.1.

\subsubsection{Results of overall curve fitting and isoleucine requirements as a function of age}

The number of studies was too limited to get reliable data from the overall regression analysis.

An overview of experiments that were included in the overall regression analysis of the experiments is presented in Appendix 9 and 10. Details of the individual experiments and estimated AFD isoleucine requirement and SID isoleucine requirement for BWG and FCR are presented in these appendixes as well. 


\section{Threonine requirement values}

\subsection{Threonine background information on meta-analysis}

\subsubsection{Study details individual studies}

In total, 31 studies each containing one or more experiments, were judged. Table 7 provides an overview of the 18 experiments from 10 papers that met the criteria described in Paragraph 2.2 for inclusion into the database. The procedure used to calculate the level of apparent faecal digestible threonine (see Par. 2.3) is also mentioned. The number of threonine supplementation levels per experiment ranged from 4 to 6 . The data in the database covered various age periods of birds. In 9 experiments males were used, in 3 experiments females were used and in 6 experiments broilers were as hatched (mixed). Different strains were used in the experiments.

\section{Table 7}

List of references that met the inclusion criteria for further evaluation of the threonine requirement of broilers in the present study.

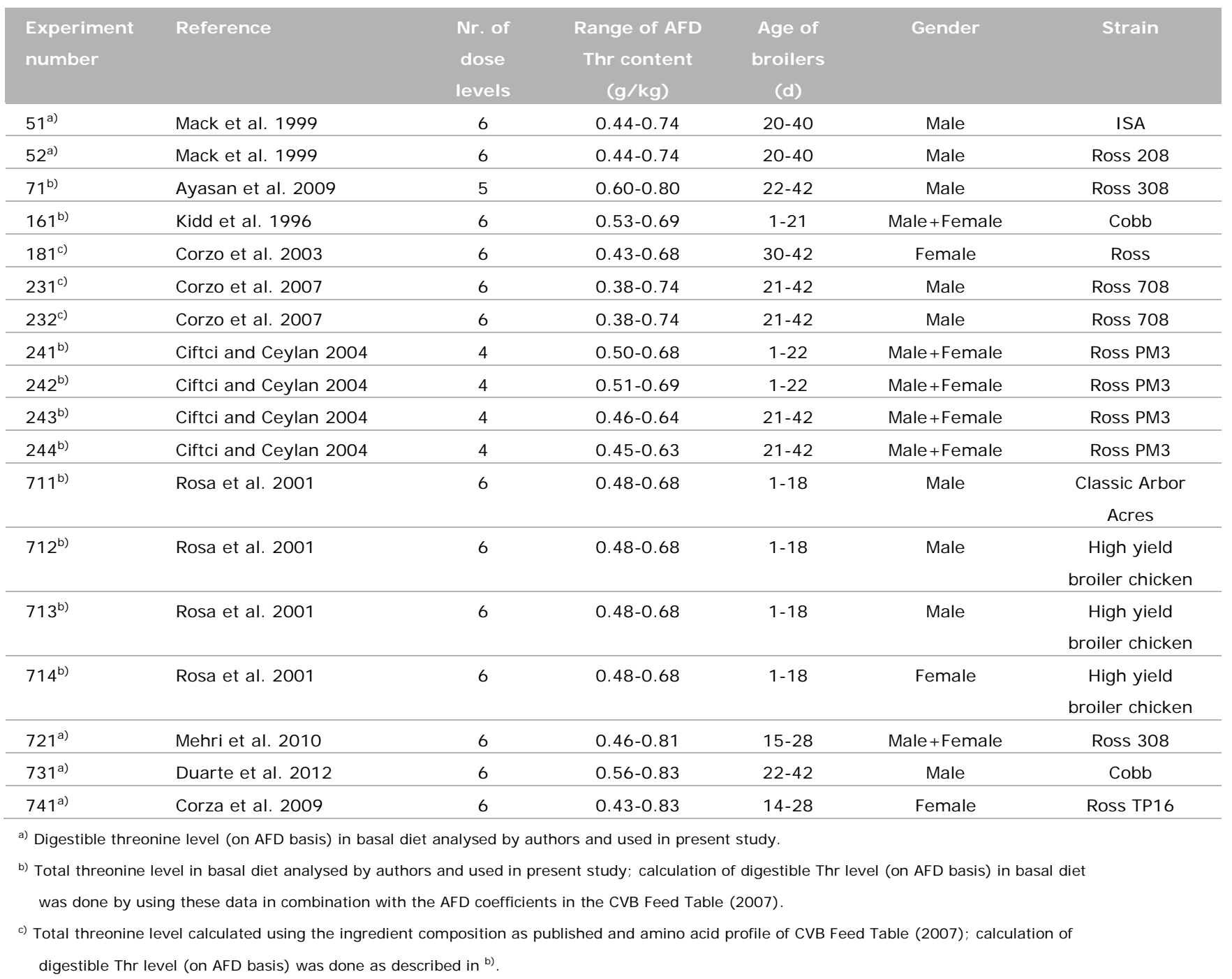




\subsubsection{Results of curve fitting and threonine requirements for individual studies}

In general, the response of BWG and FCR to AFD and SID threonine content in the experimental diet showed an exponential relationship, when using as input data the mean data for BWG and FCR per experimental group as provided in the original paper. The response of BWG and FCR to graded supplementation levels of dietary threonine was determined for all individual experiments according to exponential model (1) described in paragraph 2.4.1.

The requirement for AFD and SID threonine was determined for each study and defined as the dietary threonine concentration at which $95 \%$ of the response (difference between performance at no additional threonine supplementation and the performance at the asymptotic value) was met according to equation (2) in the paragraph 2.4.1.

\subsubsection{Results of overall curve fitting and threonine requirements as a function of age}

For estimating the AFD and SID threonine requirement as a function of age, an overall regression analysis was conducted on AFD and SID threonine requirement values derived from the individual experiments and the mean age in these experiments according to the general model (3) described in paragraph 2.4.2.

An overview of experiments that were included in the overall regression analysis of the experiments is presented in Appendix 11 and 12. Details of the individual experiments and estimated AFD threonine requirement and SID threonine requirement for BWG and FCR are presented in these appendixes as well.

\subsection{Threonine requirement values}

In paragraph 8.2.1 up to paragraph 8.2.4 the results of the overall regression analysis on requirement values derived from individual experiments are presented in graphs. Threonine requirement values in these paragraphs are expressed on AFD or SID basis on content in the diet and are expressed for BWG as well as FCR.

8.2.1 Requirement of AFD threonine expressed on dietary content for body weight gain

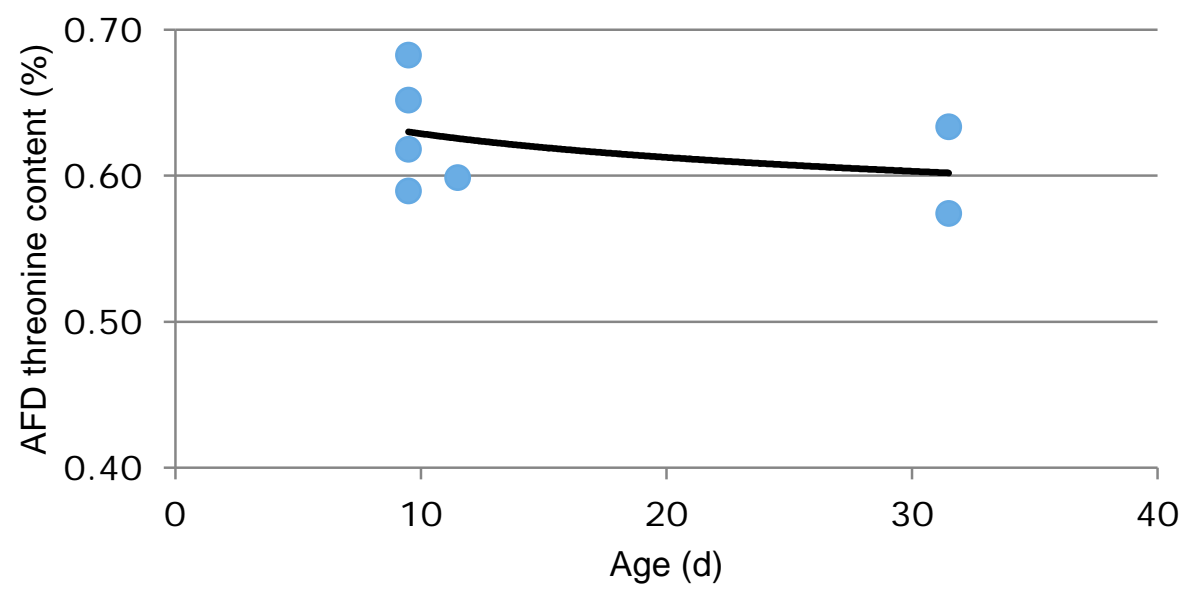

Figure 16 Requirement of AFD threonine content (\% in diet) for body weight gain at different ages (based on Exp.no.231, 241, 243, 711, 712, 713 and 714). 
The fitted requirement of AFD threonine, expressed as a percentage of diet, for BWG at different ages was based on 7 experiments. The mean ages in the different experiments were not well distributed over the entire production period. The variation in threonine requirement values, especially at young ages, was large. The relation between the threonine requirement and age for BWG on AFD basis was not significant.

\subsubsection{Requirement of AFD threonine expressed on dietary content for feed conversion ratio}

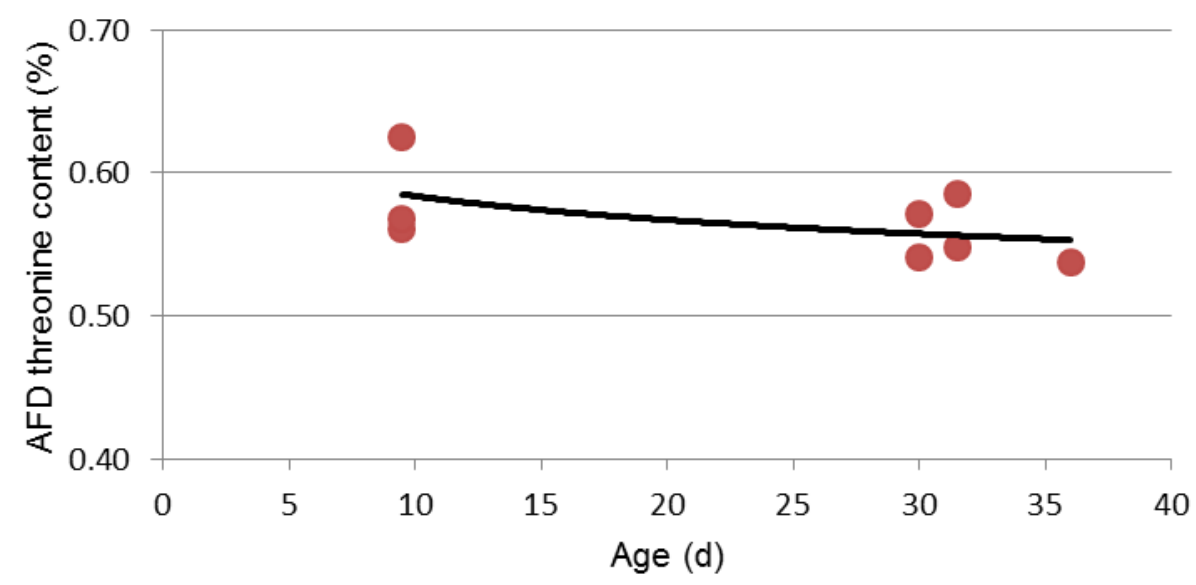

Figure 17 Requirement of AFD threonine content (\% in diet) for feed conversion ratio at different ages (based on Exp.no. 51, 52, 181, 231, 232, 711, 712 and 713).

The fitted requirement of AFD threonine content, expressed as a percentage of diet, for FCR at different ages was based on 8 experiments. The mean ages in the different experiments were not well distributed over the entire production period. The variation in threonine requirement values, especially at young ages, was large. The relation between the threonine requirement and age for BWG on AFD basis was not significant.

8.2.3 Requirement of SID threonine expressed on dietary content for body weight gain

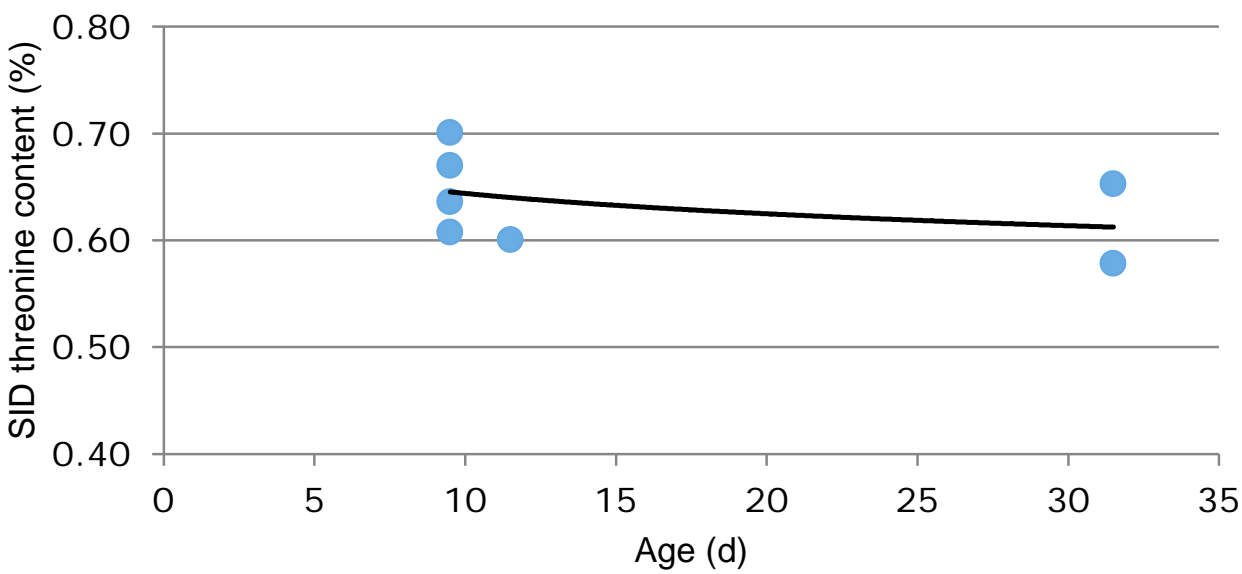

Figure 18 Requirement of SID threonine content (\% in diet) for body weight gain at different ages (based on Exp.no. 231, 241, 243, 711, 712, 713 and 714). 
The fitted requirement of SID threonine, expressed as a percentage of diet, for BWG at different ages was based on 7 experiments. The mean ages in the different experiments were not well distributed over the entire production period. The variation in threonine requirement values, especially at young ages, was large. The relation between the threonine requirement and age for BWG on SID basis was not significant.

\subsubsection{Requirement of SID threonine expressed on dietary content for feed conversion ratio}

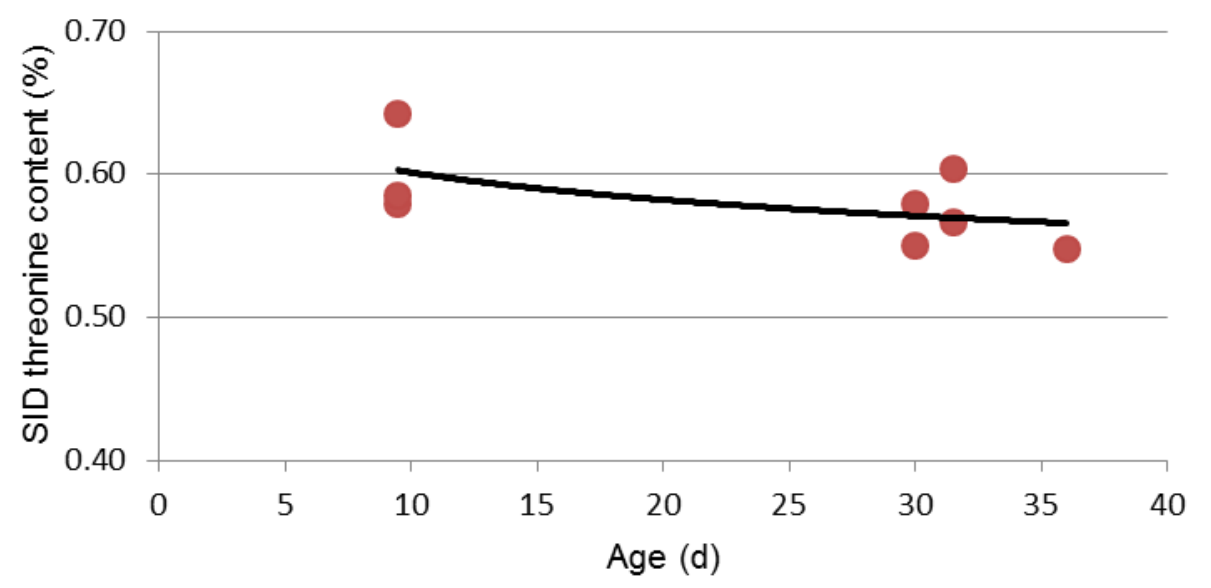

Figure 19 Requirement of SID threonine content (\% in diet) for feed conversion ratio at different ages (based on Exp.no 51, 52, 181, 231, 232, 711, 712 and 713).

The fitted requirement of SID threonine, expressed as a percentage of diet, for FCR at different ages was based on 8 experiments. The mean ages in the different experiments were not well distributed over the entire production period. The variation in threonine requirement values, especially at young ages, was large. The relation between the threonine requirement and age for BWG on SID basis was not significant. 


\section{Tryptophan requirement values}

\subsection{Tryptophan background information on meta-analysis}

\subsubsection{Study details individual studies}

In total, 10 studies each containing one or more experiments, were judged. Table 8 provides an overview of the 11 experiments from 6 papers that met the criteria described in Paragraph 2.2 for inclusion into the database. The procedure used to calculate the level of apparent faecal digestible tryptophan (see Par. 2.3) is also mentioned. The number of tryptophan supplementation levels per experiment ranged from 5 to 10. The data in the database covered various age periods of birds. In 9 experiments males were used and in 2 experiments females were used. Different strains were used in the experiments.

\section{Table 8}

List of references that met the inclusion criteria for further evaluation of the tryptophan requirement of broilers in the present study.

\begin{tabular}{|c|c|c|c|c|c|c|}
\hline $\begin{array}{l}\text { Experiment } \\
\text { number }\end{array}$ & Reference & $\begin{array}{c}\text { Nr. of dose } \\
\text { levels }\end{array}$ & $\begin{array}{l}\text { Range of AFD } \\
\text { Trp content } \\
(\mathrm{g} / \mathrm{kg})\end{array}$ & $\begin{array}{l}\text { Age of } \\
\text { broilers } \\
\text { (d) }\end{array}$ & Gender & Strain \\
\hline 33 & Corzo et al. 2005b & 7 & $0.10-0.22$ & $1-20$ & Male & Ross 508 \\
\hline 41 & Fatufe et al. 2005 & 10 & $0.06-0.24$ & $8-21$ & Male & Ross \\
\hline 53 & Shan et al. 2003 & 6 & $0.08-0.20$ & $7-21$ & Male & Cobb \\
\hline 61 & Rosa et al. 2001 & 6 & $0.08-0.23$ & $1-18$ & Male & $\begin{array}{c}\text { Arbor Acres } \\
\text { Classic }\end{array}$ \\
\hline 62 & Rosa et al. 2001 & 6 & $0.08-0.23$ & $1-18$ & Male & $\begin{array}{c}\text { Arbor Acres High } \\
\text { Yield }\end{array}$ \\
\hline 63 & Rosa et al. 2001 & 6 & $0.08-0.23$ & $1-18$ & Male & Ross 308 \\
\hline 71 & Castro et al. 2000 & 5 & $0.13-0.19$ & $1-21$ & Male & Hubbard \\
\hline 72 & Castro et al. 2000 & 5 & $0.13-0.19$ & $1-21$ & Female & Hubbard \\
\hline 81 & Mack et al. 1999 & 6 & $0.13-0.19$ & $20-40$ & Male & Ross 208 \\
\hline $\begin{array}{l}\text { a) Digestible TRP I } \\
\text { b) Total TRP level } \\
\text { by using these }\end{array}$ & $\begin{array}{l}\text { el (on AFD basis) in basa } \\
\text { basal diet analysed by a } \\
\text { ata in combination with } t\end{array}$ & $\begin{array}{l}\text { sed by authors an } \\
\text { used in present st } \\
\text { fficients in the CV }\end{array}$ & $\begin{array}{l}\text { present study. } \\
\text { ablation of digestible } \\
\text { able (2007). }\end{array}$ & evel (on AFD & is) in basal & was done \\
\hline
\end{tabular}

\subsubsection{Results of curve fitting and tryptophan requirements for individual studies}

In general, the response of BWG and FCR to AFD and SID tryptophan content in the experimental diet showed an exponential relationship, when using as input the mean data for BWG and FCR per experimental group as provided in the original paper. The response of BWG and FCR to graded supplementation levels of dietary tryptophan was determined for all individual experiments according to the exponential model (1) described in paragraph 2.4.1.

The requirement for AFD and SID tryptophan was determined for each study and defined as the dietary tryptophan concentration at which $95 \%$ of the response (difference between performance at no 
additional tryptophan supplementation and the performance at the asymptotic value) was met according to equation (2) in the paragraph 2.4.1.

\subsubsection{Results of overall fitting and tryptophan requirements as a function of age}

For estimating the AFD and SID tryptophan requirement as a function of age, an overall regression analysis was conducted on AFD and SID tryptophan requirement values derived from the individual experiments and the mean age in these experiments according to the general model (3) described in paragraph 2.4.2.

An overview of experiments that were included in the overall regression analysis of the experiments is presented in Appendix 13 and 14. Details of the individual experiments and estimated AFD tryptophan requirement and SID tryptophan requirement for BWG and FCR are presented in these appendixes as well.

\subsection{Tryptophan requirement values}

In paragraph 9.2.1 up to paragraph 9.2.4 the results of the overall regression analyses on requirement values derived from individual experiments are presented in graphs. Tryptophan requirement values in these paragraphs are expressed on AFD or SID basis, on content in the diet and are expressed for BWG as well as FCR.

\subsubsection{Requirement of AFD tryptophan expressed on dietary content for body weight} gain

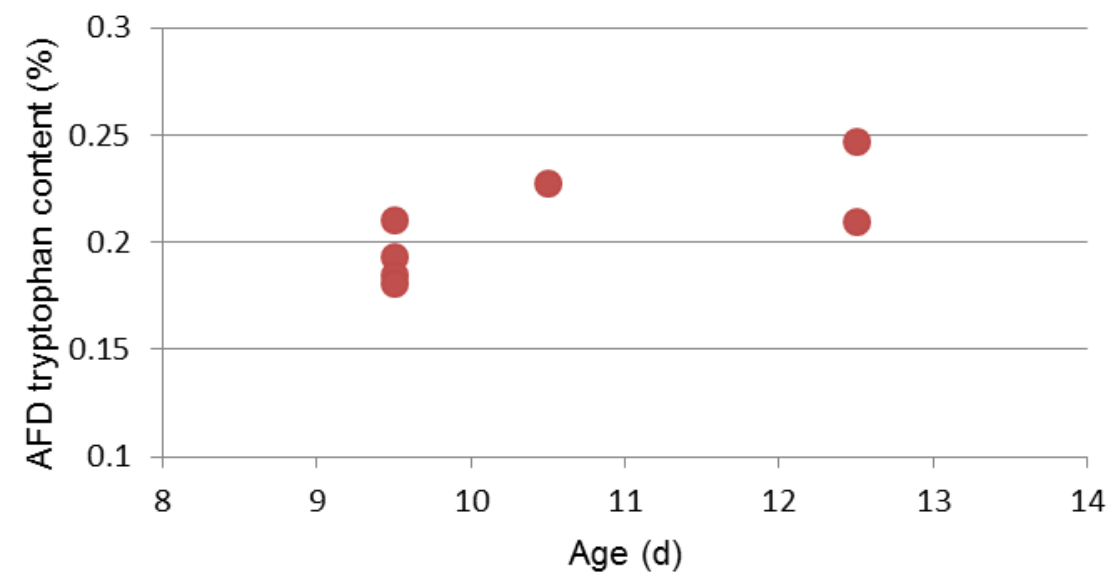

Figure 20 Requirement of AFD tryptophan content (\% in diet) for body weight gain at different ages (based on Exp.no 33, 53, 54, 61, 62, 63 and 64). 
9.2.2 Requirement of AFD tryptophan expressed on dietary content for feed conversion ratio

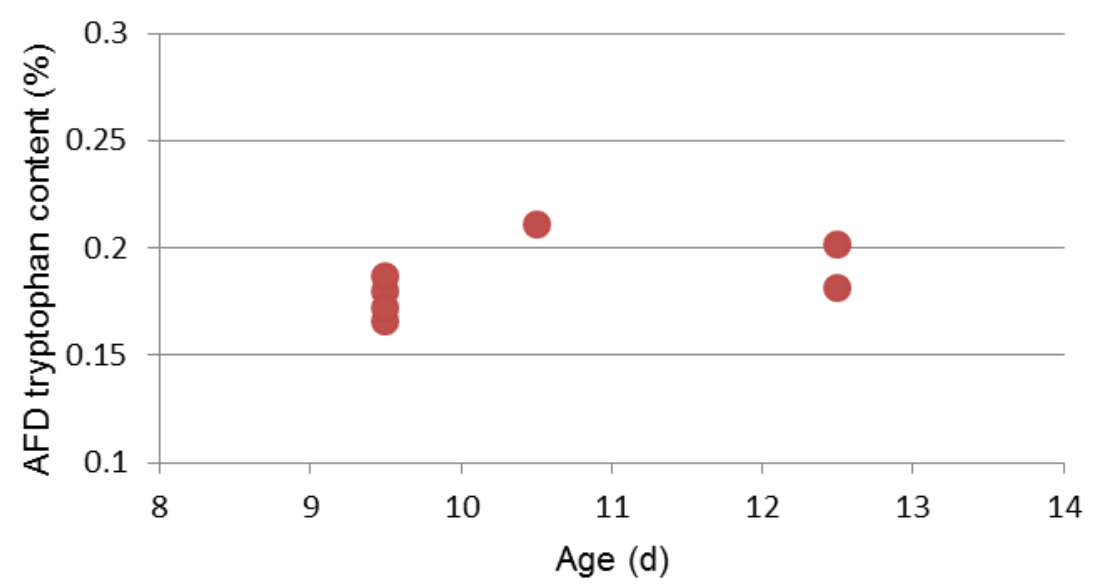

Figure 21 Requirement of AFD tryptophan content (\% in diet) for feed conversion ratio at different ages (based on Exp.no. 33, 53, 54, 61, 62, 63 and 64).

9.2.3 Requirement of SID tryptophan expressed on dietary content for body weight gain

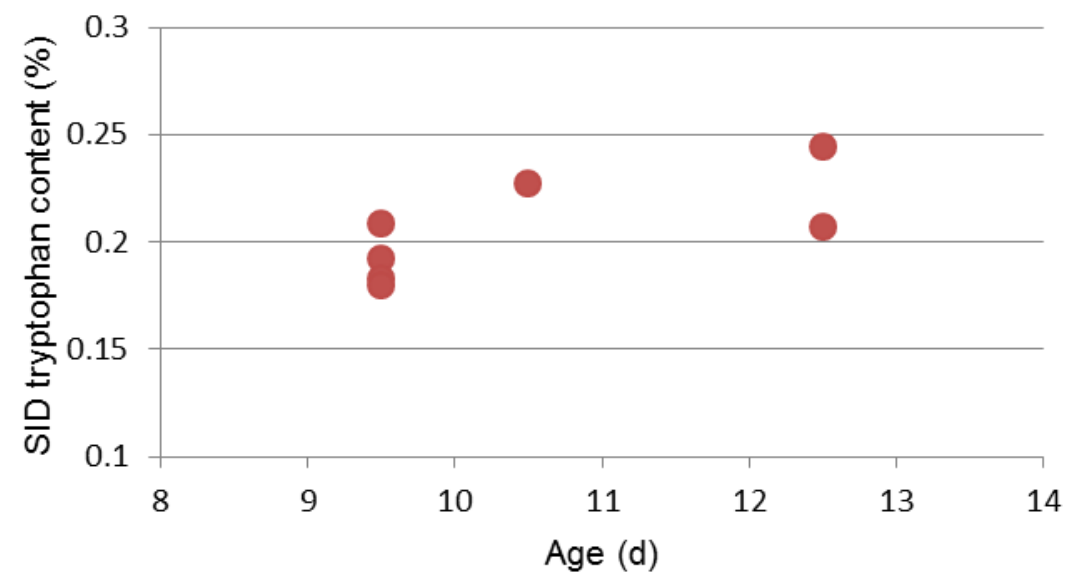

Figure 22 Requirement of SID tryptophan content (\% in diet) for body weight gain at different ages (based on Exp.no 33, 53, 54, 61, 62, 63 and 64). 
9.2.4 Requirement of SID tryptophan expressed on dietary content for feed conversion ratio

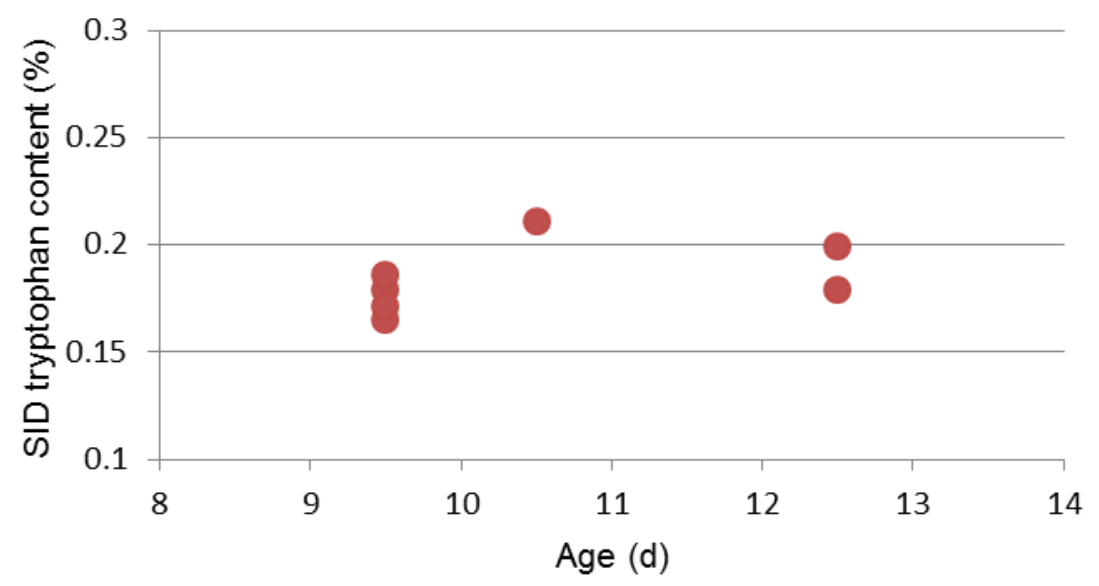

Figure 23 Requirement of SID tryptophan content (\% in diet) for feed conversion ratio at different ages (based on Exp.no 33, 53, 54, 61, 62, 63 and 64). 


\section{Requirement values of lysine on AFD and SID basis, expressed as content in the diet, at different ages for BWG and FCR}

The overall regression analyses for the requirement values of AFD and SID lysine content for BWG and FCR as a function of age, resulted in the formulas presented in Table 9. In all cases, lysine requirement decreased with age significantly.

\section{Table 9}

Mathematical description of the AFD and SID lysine requirement, expressed as content in the diet, for BWG and FCR as a function of age based on the overall regression analysis (standard errors in brackets)

\begin{tabular}{llc} 
& Overall regression analysis ${ }^{1}$ & P-value for age \\
AFD / BWG & $Y=1.390(0.1259)-0.1050(0.04145) *$ LN(age) & 0.028 \\
\hline AFD/FCR & $Y=1.461(0.0867)-0.1020(0.02730) *$ LN(age) & 0.010 \\
\hline SID/BWG & $Y=1.400(0.1200)-0.1006(0.03952) *$ LN(age) & 0.027 \\
\hline SID/FCR & $Y=1.468(0.0898)-0.0968(0.02829) *$ LN(age) & 0.014 \\
\hline
\end{tabular}

1) $Y=$ lysine content in the diet $(\%)$.

Estimated AFD and SID lysine requirements for BWG are lower than for FCR (Table 10). Until three weeks of age the AFD and SID lysine requirement for BWG are significantly higher than the CVB (2007) recommendations for AFD lysine requirement. AFD and SID lysine requirement for FCR are over the entire period significantly higher than the CVB (2007) recommendations for AFD lysine requirement. 


\section{Table 10}

Requirement of lysine content (\% of diets) according to the regression models for body weight gain and feed conversion ratio

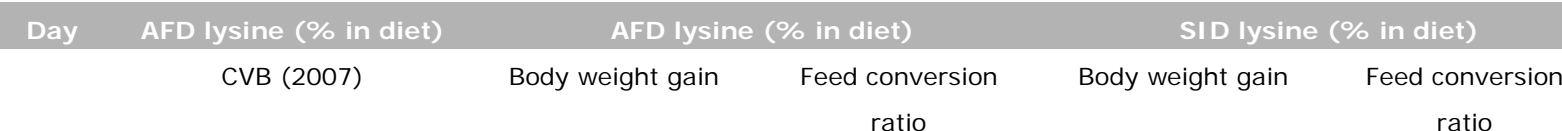

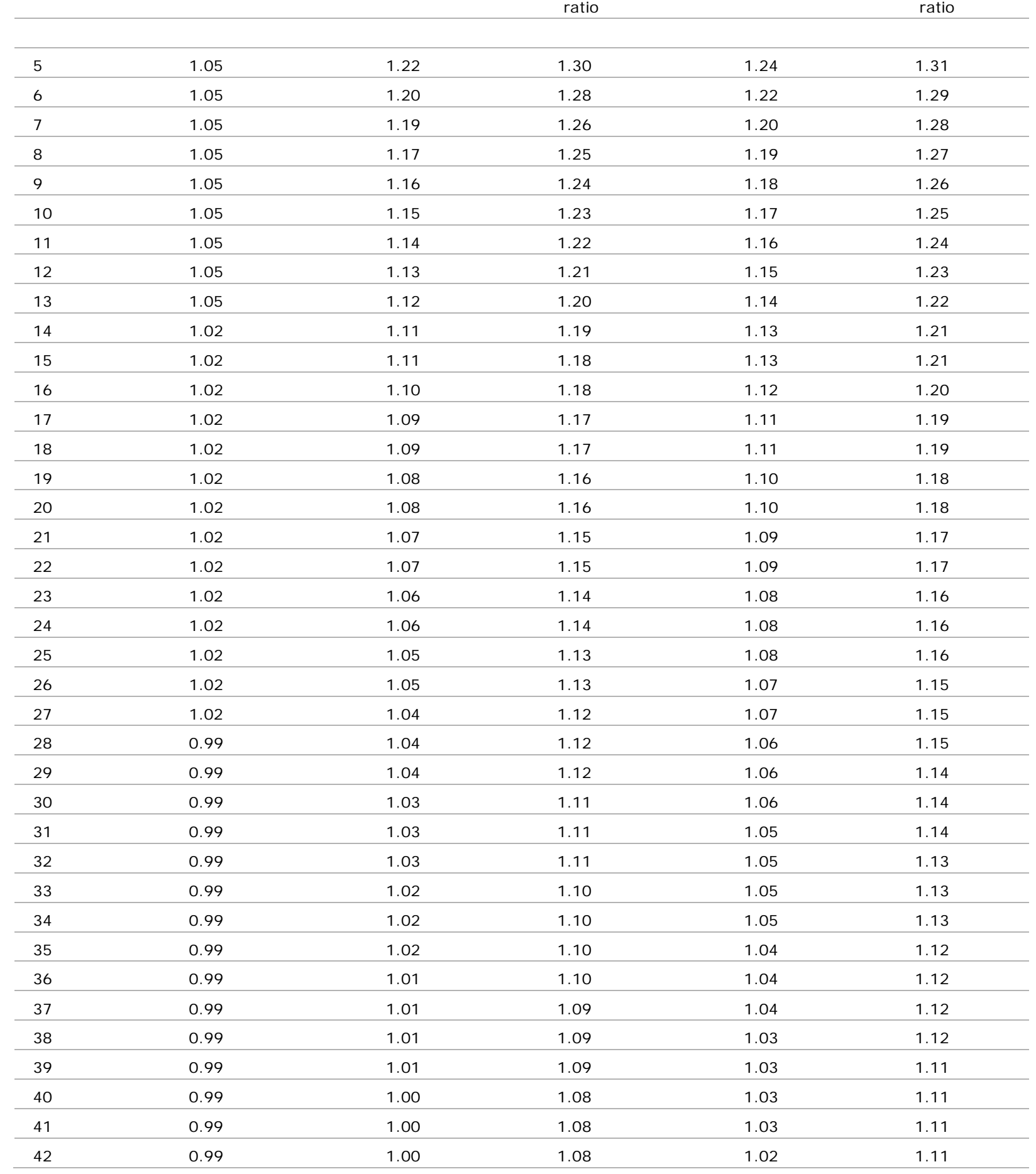




\section{Requirement values of methionine+cysteine on AFD and SID basis, expressed as content in the diet at different ages for BWG and FCR}

The overall regression analyses for the requirement values of AFD and SID methionine+cysteine content for BWG and FCR as a function of age, resulted in the formulas presented in Table 11. In all cases, methionine+cysteine requirement was not affected significantly by age.

\section{Table 11}

Mathematical description of the AFD and SID methionine+cysteine requirement expressed as content in the diet for BWG and FCR as a function of age based on the overall regression analysis (standard errors in brackets)

\begin{tabular}{lll} 
& Overall regression analysis ${ }^{1}$ & P-value for age \\
AFD/BWG & $\mathrm{Y}=0.9357(0.1440)-0.0794(0.05270) *$ LN(age $)$ & 0.15 \\
\hline AFD/FCR & $\mathrm{Y}=0.5577(0.2774)+0.0586(0.10187) *$ LN (age) & 0.58 \\
\hline SID/BWG & $\mathrm{Y}=0.8556(0.1322)-0.0514(0.04840) *$ LN (age $)$ & 0.30 \\
\hline SID/FCR & $Y=0.4530(0.2530)+0.0964(0.09289) *$ LN (age) & 0.32 \\
\hline
\end{tabular}

1): $Y=$ methionine+cysteine content in the diet (\%).

As mentioned in the previous paragraph, the relation between the methionine+cysteine requirement, expressed as content in the diet for BWG and FCR on AFD and SID basis, and age was not significant. This desk study does not result in reliable information to estimate the required methionine+cysteine levels for broilers at different ages. 


\section{Requirement values of valine on AFD and SID basis, expressed as content in the diet at different ages for BWG and FCR}

The overall regression analyses for the requirement values of AFD and SID valine content for BWG and FCR as a function of age, resulted in the formulas presented in Table 12. Valine requirement based on AFD as well as SID showed a significant decrease with age for FCR.

\section{Table 12}

Mathematical description of the AFD and SID valine requirement, expressed as content in the diet for BWG and FCR as a function of age based on the overall regression analysis (standard errors in brackets)

\begin{tabular}{lll} 
& Overall regression analysis ${ }^{1}$ & P-value for age \\
AFD/BWG & $Y=1.151(0.1447)-0.1175(0.04716) * \mathrm{LN}($ age $)$ & 0.13 \\
\hline AFD/FCR & $\mathrm{Y}=1.343(0.0034)-0.1919(0.00110) * \mathrm{LN}($ age $)$ & $<0.001$ \\
\hline SID/BWG & $\mathrm{Y}=1.129(0.1224)-0.1057(0.03992) * \mathrm{LN}($ age $)$ & 0.12 \\
\hline $\mathrm{SID} / \mathrm{FCR}$ & $\mathrm{Y}=1.321(0.0391)-0.1800(0.01275) * \mathrm{LN}($ age $)$ & 0.005 \\
\hline
\end{tabular}

1): $\mathrm{Y}=$ valine content in the diet $(\%)$.

Until 14 days of age the AFD and SID valine requirement values for FCR are slightly higher than the CVB (1996) recommendations for AFD valine requirement (Table 13). From 17 days of age AFD and SID valine requirement values for FCR were lower than the CVB (1996) recommendations for AFD valine requirement. 


\section{Table 13}

Requirement of valine content (\% of diets) according to the regression models for body weight gain and feed conversion ratio

\begin{tabular}{|c|c|c|c|c|c|}
\hline \multirow[t]{2}{*}{ Day } & \multirow{2}{*}{$\begin{array}{l}\text { AFD valine ( } \% \text { in diet) } \\
\text { CVB (2007) }\end{array}$} & \multicolumn{2}{|c|}{ AFD valine ( $\%$ in diet) } & \multicolumn{2}{|c|}{ SI D valine ( $\%$ in diet) } \\
\hline & & $\begin{array}{l}\text { Body weight } \\
\text { gain }\end{array}$ & $\begin{array}{c}\text { Feed } \\
\text { conversion } \\
\text { ratio }\end{array}$ & $\begin{array}{c}\text { Body weight } \\
\text { gain }\end{array}$ & $\begin{array}{c}\text { Feed } \\
\text { conversion } \\
\text { ratio }\end{array}$ \\
\hline 5 & 0.84 & - & 1.03 & - & 1.03 \\
\hline 6 & 0.84 & - & 1.00 & - & 1.00 \\
\hline 7 & 0.84 & - & 0.97 & - & 0.97 \\
\hline 8 & 0.84 & - & 0.94 & - & 0.95 \\
\hline 9 & 0.84 & - & 0.92 & - & 0.93 \\
\hline 10 & 0.84 & - & 0.90 & - & 0.91 \\
\hline 11 & 0.84 & - & 0.88 & - & 0.89 \\
\hline 12 & 0.84 & - & 0.87 & - & 0.87 \\
\hline 13 & 0.84 & - & 0.85 & - & 0.86 \\
\hline 14 & 0.82 & - & 0.84 & - & 0.85 \\
\hline 15 & 0.82 & - & 0.82 & - & 0.83 \\
\hline 16 & 0.82 & - & 0.81 & - & 0.82 \\
\hline 17 & 0.82 & - & 0.80 & - & 0.81 \\
\hline 18 & 0.82 & - & 0.79 & - & 0.80 \\
\hline 19 & 0.82 & - & 0.78 & - & 0.79 \\
\hline 20 & 0.82 & - & 0.77 & - & 0.78 \\
\hline 21 & 0.82 & - & 0.76 & - & 0.77 \\
\hline 22 & 0.82 & - & 0.75 & - & 0.76 \\
\hline 23 & 0.82 & - & 0.74 & - & 0.76 \\
\hline 24 & 0.82 & - & 0.73 & - & 0.75 \\
\hline 25 & 0.82 & - & 0.73 & - & 0.74 \\
\hline 26 & 0.82 & - & 0.72 & - & 0.73 \\
\hline 27 & 0.82 & - & 0.71 & - & 0.73 \\
\hline 28 & 0.79 & - & 0.70 & - & 0.72 \\
\hline 29 & 0.79 & - & 0.70 & - & 0.71 \\
\hline 30 & 0.79 & - & 0.69 & - & 0.71 \\
\hline 31 & 0.79 & - & 0.68 & - & 0.70 \\
\hline 32 & 0.79 & - & 0.68 & - & 0.70 \\
\hline 33 & 0.79 & - & 0.67 & - & 0.69 \\
\hline 34 & 0.79 & - & 0.67 & - & 0.69 \\
\hline 35 & 0.79 & - & 0.66 & - & 0.68 \\
\hline 36 & 0.79 & - & 0.66 & - & 0.68 \\
\hline 37 & 0.79 & - & 0.65 & - & 0.67 \\
\hline 38 & 0.79 & - & 0.64 & - & 0.67 \\
\hline 39 & 0.79 & - & 0.64 & - & 0.66 \\
\hline 40 & 0.79 & - & 0.64 & - & 0.66 \\
\hline 41 & 0.79 & - & 0.63 & - & 0.65 \\
\hline 42 & 0.79 & - & 0.63 & - & 0.65 \\
\hline
\end{tabular}




\section{Requirement values of arginine on AFD and SID basis, expressed as content in the diet, at different ages for BWG and FCR}

For body weight gain, one experiment (experiment 111) was accepted for the overall regression analyses on requirement values.

In experiment 111, AFD and SID arginine requirement for body weight gain was estimated 1.33 and $1.32 \%$, respectively, at a mean age of 7 days. The AFD arginine requirement value recommended by CVB (2007) is $1.10 \%$ at 7 days of age.

For feed conversion ratio, three experiments (experiments 82, 111 and 112) were accepted for the overall regression on requirement values.

In experiment 82, AFD and SID arginine requirement value for feed conversion ratio was estimated 1.09 and $1.00 \%$, respectively, at a mean age of 14 days. In experiment 111, AFD and SID arginine requirement value for feed conversion ratio was estimated 1.37 and $1.35 \%$ at a mean age of 7 days of age. In experiment 112, AFD and SID arginine requirement value for feed conversion ratio was estimated 1.18 and $1.09 \%$, respectively, at a mean age of 21.5 days. The AFD arginine requirement value recommended by CVB (2007) is $1.10 \%$ for the period $0-14$ days of age and $1.07 \%$ for the period 14-28 days of age. 


\section{Requirement values of isoleucine on AFD and SID basis, expressed as content in the diet, at different ages for BWG and FCR}

Based on the overall regression analyses, only three experiments were accepted for overall regression on requirement values. For BWG experiments 11 and 12 and for FCR experiments 11 and 51 were accepted. In experiment 11, AFD and SID isoleucine requirement for BWG was estimated 0.61 and $0.56 \%$, respectively, at a mean age of 14 days and in experiment 12, AFD and SID isoleucine requirement for BWG was estimated also 0.61 and $0.56 \%$, respectively, at a mean age of 36.5 days. The AFD isoleucine requirement recommended by CVB (2007) is $0.67 \%$ at 14 days of age and $0.65 \%$ at 35 days of age. In experiment 11, AFD and SID isoleucine requirement for FCR was estimated 0.61 and $0.56 \%$, respectively, at a mean age of 14 days and in experiment 51, AFD and SID isoleucine requirement for FCR was estimated 0.55 and $0.56 \%$, respectively, at a mean age of 30 days. The AFD isoleucine requirement recommended by CVB (2007) is $0.67 \%$ at 14 days of age and $0.65 \%$ at 35 days of age. 


\section{Requirement values of threonine on AFD and SID basis, expressed as content in the diet, at different ages for BWG and FCR}

The overall regression analyses for the requirement values of AFD and SID threonine content for BWG and FCR as a function of age, resulted in the formulas presented in Table 14. The relation between the threonine requirement and age for BWG and FCR on AFD and SID basis was not significant.

\section{Table 14}

Mathematical description of the AFD and SID threonine requirement, expressed as content in the diet, for BWG and FCR as a function of age based on the overall regression analysis (standard errors in brackets)

\begin{tabular}{lll} 
& Overall regression analysis ${ }^{1)}$ & P-value for age \\
AFD / BWG & $Y=0.683(0.0742)-0.0235(0.02775) *$ LN(age) & 0.44 \\
\hline AFD/FCR & $Y=0.639(0.0481)-0.0240(0.01570) *$ LN(age) & 0.18 \\
\hline SID/BWG & $Y=0.707(0.0835)-0.0275(0.03121) * L N($ age $)$ & 0.42 \\
\hline SID/FCR & $Y=0.665(0.0505)-0.0278(0.01648) * L N($ age $)$ & 0.14 \\
\hline
\end{tabular}

${ }^{1)}: Y=$ threonine content in the diet $(\%)$.

The relation between the threonine requirement for BWG and FCR on AFD and on SID basis and age was not significant, which means that this desk study does not result in reliable information to estimate the levels of required threonine for broilers at different ages. 


\section{Requirement values of tryptophan on AFD and SID basis, expressed as content in the diet, at different ages for BWG and FCR}

Requirement values of AFD and SID tryptophan content at different ages for BWG and FCR were restricted to the age period of 9.5 to 12.5 days of age; so it is not possible to estimate the requirement values for the total age period. 


\section{Acknowledgement}

The CVB project group 'Digestible Amino Acids Poultry', consisting of scientists and representatives of the Dutch feed industry, guided this study. The authors would like to acknowledge with much appreciation the members of this project group for their valuable input to all phases of this project. The members of the CVB project group 'Digestible Amino Acids Poultry' were:

Alfons Jansman

Bart Swart

Cees Kwakernaak

Carolien Makkink

Henk Everts

Machiel Blok

Marien van den Brink

Marinus van Krimpen

Mario van Erp

Masja Lensing

Peter Wijtten

Rene Kwakkel

Ruud Dekker

Teun Veldkamp

Walter Gerrits

Wouter Spek 


\section{Literature}

Adedokun, S. A., C. M. Parsons, O. Adeola, M. Lilburn, and T. J. Applegate. 2008. Comparison of apparent and standardized amino acid digestibility of feed ingredients in cecectomized roosters, laying hens, and broilers. Poult. Sci. 87: 145-145.

Aftab, U., M. Ashraf, A.S. Mumtaz, Z. Jiang. 2007. Lysine Requirement of Broiler Chickens Fed Lowdensity Diets under Tropical Conditions. Asian-Aust. J. Anim. Sci. Vol. 20, No. 6 : 939 - 943.

Berri, C., J. Besnard, C. Relandeau. 2008. Increasing Dietary Lysine Increases Final pH and Decreases Drip Loss of Broiler Breast Meat. Poultry Science 87:480-484.

Campestrini, E., M.J.B. Barbosa, R.V. Nunes, E. Gasparino, W.T.M. da Silva, R. Khül. 2010. Level digestible lysine with two electrolyte balances for broiler chicks at the starting phase (1-21 day). R. Bras. Zootec., v.39, n.1, p.151-157.

Coca-Sinova, A., E. Jeménez-Moreno, J.M. González-Alvarado, M. Frikha, R. Lázaro, G.G. Mateos. 2010. Influence of source of soybean meal and lysine content of the diet on performance and total tract apparent retention of nutrients in broilers from 1 to 36 days of age. Poultry Science 89: 14401450.

Corzo, A., L. Mejia, C.D. McDaniel, J.S. Mortiz. 2012. Interactive effects of feed form and dietary lysine on growth responses of commercial broiler chicks. J. Appl. Poult. Res. 21 :70-78.

CVB. 1996. Amino acid requirement of laying hens and broiler chicks. Schutte, J.B. (ed.). CVB Report No. 18.

CVB. 2007. Veevoedertabel 2007, centraal veevoederbureau. Lelystad, The Netherlands. Uitgave mei 2007.

CVB. 2012. Tabellenboek veevoeding 2012. CVB-reeks nr. 50, Productschap Diervoeder, Den Haag, Augustus 2012.

Dekker, R., and M. C. Blok. 2012. Gestandaardiseerde ileale aminozuurverteerbaarheid van voedermiddelen voor pluimvee. DVAZP 43.

Dozier, W.A., A. Corzo, M.T. Kidd, M.W. Schilling. 2008. Dietary Digestible Lysine Requirements of Male and Female Broilers from Forty-Nine to Sixty-Three Days of Age. Poultry Science 87: 1385- 1391.

Dozier, W.A., A. Corzo, M.T. Kidd, P.B. Tillman, S.L. Branton. 2009. Digestible lysine requirements of male and female broilers from fourteen to twenty-eight days of age. Poultry Science $88: 1676$ 1682.

Dozier, W.A., A. Corzo, M.T. Kidd, P.B. Tillman, J.P. McMurtry, S.L. Branton. 2010. Digestible lysine requirements of male broilers from 28 to 42 days of age. Poultry Science 89 :2173-2182.

Dozier, W.A., R.L. Payne. 2012. Digestible lysine requirements of female broilers from 1 to 15 days of age. J. Appl. Poult. Res. 21 :348-357.

Fatufe, A.A., R. Timmler, M. Rodehutscord. 2004. Response to Lysine Intake in Composition of Body Weight Gain and Efficiency of Lysine Utilization of Growing Male Chickens from Two Genotypes. Poultry Science 83: 1314-1324.

Garcia, A.R., A.B. Batal, D.H. Baker. 2006. Variations in the Digestible Lysine Requirement of Broiler Chickens Due to Sex, Performance Parameters, Rearing Environment, and Processing Yield Characteristics. Poultry Science 85:498-504

Hassan, H.M.A., M.A. Mohamed, T.M. El-Afifi. 2011. Effect of phytase or lysine supplementation on performance of broilers fed lysine deficient diet from 21 to 42 days of age. Department of Animal Production, National Research Centre, 12622, Dokki, Egypt. Received: 26/02/2011. Accepted: 06/03/2011.

Knowles, T.A., L.L. Southern. 1998. The Lysine Requirement and Ratio of Total Sulfur Amino Acids to Lysine for Chicks Fed Adequate or Inadequate Lysine. Poultry Science 77: 564-569.

Lemme, A., P.J.A. Wijtten, J. van Wichen, A. Petri, D.J. Langhout. 2006. Responses of Male Growing Broilers to Increasing Levels of Balanced Protein Offered as Coarse Mash or Pellets of Varying Quality. Poultry Science 85:721-730. 
Lemme, A., V. Ravindran, and W. L. Bryden. 2004. Ileal digestibility of amino acids in feed ingredients for broilers. Worlds Poult. Sci. J. 60(4):423-437.

Mahdavi, A., M. Shivazad, F. Alemi, M. Zaghari, H. Moravej, B. Darabighane. 2012. Digestible lysine requirement of broilers based on practical diet. Italian J ournal of Animal Science 2012; volume 11:e13: 68-76.

Mehri, M., H. Nassiri-Moghaddam, H. Kermanshahi, M. Danesh-Mesgaran. 2010. Digestible lysine requirements of straight-run broiler chickens form fifteen to twenty-eight days of age. Journal of Animal and Veterinary Advances 9(17): 2321-2324.

Panda, A.K., S.V. Rama Rao, M.V.L.N. Raju, G. Lavanya, E.P.K. Reddy, G.S. Sunder. 2011. Early Growth Response of Broilers to Dietary Lysine at Fixed Ratio to Crude Protein and Essential Amino Acids. Asian-Aust. J. Anim. Sci. Vol. 24, No. 11 : 1623 - 1628.

St-Pierre, N.R. 2001. I nvited review: Integrating quantitative findings from multiple studies using mixed model methodology. J. Dairy Sci. 84:741-755.

Strathe, A.B., A. Lemme, J.K. Htoo, E. Kebreab. 2011. Estimating digestible methionine requirements for laying hens using multivariate nonlinear mixed effect models. Poultry Science $90: 1496-1507$.

Takeara, P., A.L. Toledo, E.R.S. Gandra, R. Albuquerque, M.A. Trindade Neto. 2010. Digestible lysine for male broilers from 12 to 22 days of age. Arq. Bras. Med. Vet. Zootec., v.62, n.6, p.1455-1461.

Toledo, R.S., H.S. Rostagno, L.F.T. Albino, M.A. Dionizio, D.C. de Oliveira Carvalho, E.T. Nogueira. 2011. Lysine nutritional requirements of broilers reared in clean and dirty environments during the prestarter and starter phases. R. Bras. Zootec., v.40, n.10, p.2205-2210.

Trindade Neto, M.A., A.L. de Toledo, P. Takeara, E. Kobashigawa, D.C.Z. Donato, R. de Albuquerque. 2011. Dietary levels of lysine for male broilers from 23 to 36 days of age: performance and body composition. R. Bras. Zootec., v.40, n.3, p.609-615, 2011.

Trindade Neto, M.A., L.B. Namazu, E. Kobashigawa, P. Takeara, D.C.Z. Donato, R. de Albuquerque. 2011. Digestible lysine and organic zinc for male broiler from 1 to 11 days of age: performance and body composition. R. Bras. Zootec., v.40, n.3, p.602-608.

Van Houwelingen, H.C., L.R. Arends, T. Stijnen. 2002. Advanced methods in meta-analysis: Multivariate approach and meta-regression. Stat. Med. 21:589-624.

Wijtten, P.J.A., A. Lemme, D.J. Langhout. 2004. Effects of Different Dietary I deal Protein Levels on Male and Female Broiler Performance During Different Phases of Life: Single Phase Effects, Carryover Effects, and Interactions Between Phases. Poultry Science 83:2005-2015.

Wijtten, P.J.A., R. Prak, A. Lemme., D.J. Langhout 2004. Effect of different dietary ideal protein concentrations on broiler performance. British Poultry Science Volume 45, Number 4 (August 2004), pp. 504-511. 
Appendices 
Appendix 1 Experiments for which the requirement on the AFD and SID lysine concentration for BWG was estimated according to equation 2 and that also met the criteria for the overall regression to estimate the relationship of the AFD and SID lysine requirement for BWG with age

\begin{tabular}{|c|c|c|c|c|c|c|c|c|c|}
\hline \multirow[t]{2}{*}{$\begin{array}{l}\text { Exp } \\
\text { No. }\end{array}$} & \multirow[t]{2}{*}{ Reference } & \multirow[t]{2}{*}{$\begin{array}{l}\text { AFD lysine concentration } \\
\text { in the diet }(\%)\end{array}$} & \multirow[t]{2}{*}{ Gender } & \multirow[t]{2}{*}{ Strain } & \multirow[t]{2}{*}{$\begin{array}{l}\text { Age of } \\
\text { birds }\end{array}$} & \multirow[t]{2}{*}{$\begin{array}{l}\text { Published } \\
\text { Requirement ( } \% \text { ) }\end{array}$} & \multirow[t]{2}{*}{$\begin{array}{l}\text { Models used by the } \\
\text { reference }\end{array}$} & \multicolumn{2}{|c|}{$\begin{array}{l}\text { Re-calculated requirement } \\
\text { using exponential models ( } \% \text { ) }\end{array}$} \\
\hline & & & & & & & & $\begin{array}{l}\text { AFD lysine } \\
\text { content for } \\
\text { BWG }\end{array}$ & $\begin{array}{l}\text { SID lysine } \\
\text { content for } \\
\text { BWG }\end{array}$ \\
\hline 11 & $\begin{array}{l}\text { Mahdavi et al } \\
\text { (2012) }\end{array}$ & $\begin{array}{l}0.77,0.84,0.91,0.98,1.05, \\
1.12\end{array}$ & Male & - & $35-49$ & 0.98 & $\begin{array}{l}\text { Broken-line, } \\
\text { exponential, quadratic }\end{array}$ & 1.05 & 1.07 \\
\hline 12 & $\begin{array}{l}\text { Mahdavi et al } \\
\text { (2012) }\end{array}$ & $\begin{array}{l}0.77,0.84,0.91,0.98,1.05, \\
1.12\end{array}$ & Female & - & $35-49$ & 0.93 & $\begin{array}{l}\text { Broken-line, } \\
\text { exponential, quadratic }\end{array}$ & 1.05 & 1.08 \\
\hline 22 & $\begin{array}{l}\text { Garcia et al } \\
(2006)\end{array}$ & $0.70,0.80,0.90,1.00$ & Male & Cobb & $7-21$ & 0.93 & Lineair and Quadratic & 1.04 & 1.07 \\
\hline 28 & $\begin{array}{l}\text { Garcia et al } \\
\text { (2006) }\end{array}$ & $0.80,0.88,0.96,1.04,1.12$ & Female & Cobb & $7-21$ & 0.97 & Lineair and Quadratic & 0.98 & 1.00 \\
\hline 212 & $\begin{array}{l}\text { Garcia et al } \\
\text { (2006) }\end{array}$ & $0.89,0.97,1.02,1.13,1.21$ & Female & Cobb & $7-21$ & 0.99 & Lineair and Quadratic & 1.01 & 1.04 \\
\hline 41 & $\begin{array}{l}\text { Dozier et al } \\
(2009)\end{array}$ & $\begin{array}{l}0.85,0.90,0.95,1.00,1.05 \\
1.10,1.15,1.20,1.25\end{array}$ & Male & Ross & $14-28$ & 1.15 & Broken-line & 1.22 & 1.23 \\
\hline 51 & $\begin{array}{l}\text { Dozier \& Payne } \\
\text { (2012) }\end{array}$ & $\begin{array}{l}0.91,1.01,1.05,1.15,1.20 \\
1.28,1.40\end{array}$ & Female & Ross & 7-15 & - & Quadratic broken line & 1.27 & 1.28 \\
\hline 52 & $\begin{array}{l}\text { Dozier \& Payne } \\
(2012)\end{array}$ & $\begin{array}{l}0.91,1.01,1.05,1.15,1.20 \\
1.28,1.40\end{array}$ & Female & Hubbard $\times$ Cobb & $7-15$ & - & Quadratic broken line & 1.17 & 1.19 \\
\hline 54 & $\begin{array}{l}\text { Dozier \& Payne } \\
\text { (2012) }\end{array}$ & $\begin{array}{l}0.91,1.01,1.05,1.15,1.20, \\
1.28,1.40\end{array}$ & Female & Hubbard $\times$ Cobb & $1-7$ & 1.35 & Quadratic broken line & 1.27 & 1.29 \\
\hline 141 & $\begin{array}{l}\text { Dozier et al } \\
\text { (2010) }\end{array}$ & $\begin{array}{l}0.64,0.71,0.78,0.85,0.92, \\
0.99,1.06,1.13,1.20\end{array}$ & Male & Ross & $28-42$ & 1.05 & Quadratic broken line & 1.09 & 1.12 \\
\hline
\end{tabular}




\begin{tabular}{|c|c|c|c|c|c|c|c|c|c|}
\hline \multirow[t]{2}{*}{$\begin{array}{l}\text { Exp } \\
\text { No. }\end{array}$} & \multirow[t]{2}{*}{ Reference } & \multirow[t]{2}{*}{$\begin{array}{l}\text { AFD lysine concentration } \\
\text { in the diet }(\%)\end{array}$} & \multirow[t]{2}{*}{ Gender } & \multirow[t]{2}{*}{ Strain } & \multirow[t]{2}{*}{$\begin{array}{l}\text { Age of } \\
\text { birds }\end{array}$} & \multirow[t]{2}{*}{$\begin{array}{l}\text { Published } \\
\text { Requirement (\%) }\end{array}$} & \multirow[t]{2}{*}{$\begin{array}{l}\text { Models used by the } \\
\text { reference }\end{array}$} & \multicolumn{2}{|c|}{$\begin{array}{l}\text { Re-calculated requirement } \\
\text { using exponential models ( } \% \text { ) }\end{array}$} \\
\hline & & & & & & & & $\begin{array}{l}\text { AFD lysine } \\
\text { content for } \\
\text { BWG }\end{array}$ & $\begin{array}{l}\text { SID lysine } \\
\text { content for } \\
\text { BWG }\end{array}$ \\
\hline 142 & $\begin{array}{l}\text { Dozier et al } \\
\text { (2010) }\end{array}$ & $\begin{array}{l}0.64,0.71,0.78,0.85,0.92, \\
0.99,1.06,1.13,1.20\end{array}$ & Male & Cobb & $28-42$ & 1.01 & Quadratic broken line & 1.01 & 1.03 \\
\hline 151 & Mack et al (1999) & $\begin{array}{l}0.66,0.75,0.84,0.93,1.02, \\
1.11\end{array}$ & Male & Ross & $20-40$ & 1.01 & Broken-line, exponential & 0.97 & 1.00 \\
\hline 152 & Mack et al (1999) & $\begin{array}{l}0.66,0.75,0.84,0.93,1.02, \\
1.11\end{array}$ & Male & ISA & $20-40$ & 1.10 & Broken-line, exponential & 0.89 & 0.92 \\
\hline
\end{tabular}


Appendix 2 Experiments for which the requirement on the AFD and SID lysine concentration for FCR was estimated according to equation 2 and that also met the criteria for the overall regression to estimate the relationship of the AFD and SID lysine requirement for FCR with age

\begin{tabular}{|c|c|c|c|c|c|c|c|c|c|}
\hline \multirow[t]{2}{*}{$\begin{array}{l}\text { Exp } \\
\text { No. }\end{array}$} & \multirow[t]{2}{*}{ Reference } & \multirow[t]{2}{*}{$\begin{array}{l}\text { SI D lysine concentration in the } \\
\text { diet }(\%)\end{array}$} & \multirow[t]{2}{*}{ Gender } & \multirow[t]{2}{*}{ Strain } & \multirow[t]{2}{*}{$\begin{array}{l}\text { Age of } \\
\text { birds }\end{array}$} & \multirow[t]{2}{*}{$\begin{array}{l}\text { Published } \\
\text { Require- } \\
\text { ment (\% ) }\end{array}$} & \multirow[t]{2}{*}{$\begin{array}{l}\text { Models used by the } \\
\text { reference }\end{array}$} & \multicolumn{2}{|c|}{$\begin{array}{l}\text { Re-calculated requirement } \\
\text { using exponential models } \\
(\%)\end{array}$} \\
\hline & & & & & & & & $\begin{array}{l}\text { AFD lysine } \\
\text { content } \\
\text { for FCR }\end{array}$ & $\begin{array}{l}\text { SID lysine } \\
\text { content for } \\
\text { FCR }\end{array}$ \\
\hline 11 & Mahdavi et al (2012) & $0.80,0.87,0.94,1.01,1.08,1.15$ & Male & - & $35-49$ & 0.98 & $\begin{array}{l}\text { Broken-line, exponential, } \\
\text { quadratic }\end{array}$ & 1.16 & 1.19 \\
\hline 12 & Mahdavi et al (2012) & $0.80,0.87,0.94,1.01,1.08,1.15$ & Female & - & $35-49$ & 0.93 & $\begin{array}{l}\text { Broken-line, exponential, } \\
\text { quadratic }\end{array}$ & 1.05 & 1.08 \\
\hline 42 & Dozier et al (2009) & $\begin{array}{l}0.86,0.91,0.96,1.01,1.06,1.11, \\
1.16,1.21,1.26\end{array}$ & Male & Ross & $14-28$ & 1.15 & Broken-line & 1.07 & 1.08 \\
\hline 52 & $\begin{array}{l}\text { Dozier \& Payne } \\
(2012)\end{array}$ & $\begin{array}{l}0.93,1.03,1.07,1.17,1.22,1.30 \\
1.42\end{array}$ & Female & Hubbard $\times$ Cobb & $7-15$ & 1.26 & Quadratic broken line & 1.29 & 1.31 \\
\hline 54 & Dozier \& Payne (2012 & $\begin{array}{l}0.93,1.03,1.07,1.17,1.22,1.30 \\
1.42\end{array}$ & Female & Hubbard $\times$ Cobb & $1-7$ & - & Quadratic broken line & 1.30 & 1.32 \\
\hline 142 & Dozier et al (2010) & $\begin{array}{l}0.66,0.73,0.80,0.87,0.94,1.01, \\
1.08,1.15,1.22\end{array}$ & Male & Cobb & $28-42$ & 1.01 & Quadratic broken line & 1.08 & 1.10 \\
\hline 151 & Mack et al (1999) & $0.71,0.80,0.89,0.98,1.07,1.16$ & Male & Ross & $20-40$ & 1.23 & Broken-line, exponential & 1.11 & 1.14 \\
\hline 152 & Mack et al (1999) & $0.71,0.80,0.89,0.98,1.07,1.16$ & Male & ISA & $20-40$ & 1.22 & Broken-line, exponential & 1.10 & 1.13 \\
\hline
\end{tabular}


Appendix 3 Experiments for which the requirement on the AFD and SID methionine+cysteine concentration for BWG was estimated according to equation 2 and that also met the criteria for the overall regression to estimate relationship of the AFD and SID methionine+cysteine requirement for BWG with age

\begin{tabular}{|c|c|c|c|c|c|c|c|c|c|}
\hline \multirow[t]{2}{*}{$\begin{array}{l}\text { Exp } \\
\text { No. }\end{array}$} & \multirow[t]{2}{*}{ Reference } & \multirow[t]{2}{*}{$\begin{array}{l}\text { AFD methionine+cysteine } \\
\text { concentration in the diet }(\%)\end{array}$} & \multirow[t]{2}{*}{ Gender } & \multirow[t]{2}{*}{ Strain } & \multirow{2}{*}{$\begin{array}{l}\text { Age } \\
\text { of } \\
\text { birds }\end{array}$} & \multirow{2}{*}{$\begin{array}{l}\text { Published } \\
\text { Requirement } \\
(\%)\end{array}$} & \multirow[t]{2}{*}{$\begin{array}{l}\text { Models used by } \\
\text { the reference }\end{array}$} & \multicolumn{2}{|c|}{$\begin{array}{l}\text { Re-calculated requirement using } \\
\text { exponential models (\%) }\end{array}$} \\
\hline & & & & & & & & $\begin{array}{l}\text { AFD } \\
\text { methionine+cysteine } \\
\text { content for BWG }\end{array}$ & $\begin{array}{l}\text { SID } \\
\text { methionine+cysteine } \\
\text { content for BWG }\end{array}$ \\
\hline 32 & Chamruspollert et al. (2002) & $0.62,0.70,0.77,0.84,0.92$ & Female & Ross & $7-14$ & 0.89 & Broken line models & 0.82 & 0.81 \\
\hline 43 & Castro Goulart et al. (2011) & $\begin{array}{l}0.56,0.62,0.68,0.74,0.80 \\
0.86\end{array}$ & Male & Cobb & $22-35$ & 0.75 & Quadratic Model & 0.70 & 0.70 \\
\hline 51 & Mack et al. (1999) & $\begin{array}{l}0.50,0.56,0.62,0.68,0.74 \\
0.80\end{array}$ & Male & Ross & $20-40$ & 0.79 & Exponential model & 0.69 & 0.71 \\
\hline 65 & Lumpkins et al. (2007) & $0.49,0.59,0.69,0.79,0.89$ & Male & Cobb & $8-19$ & 0.79 & Broken line models & 0.65 & 0.64 \\
\hline 66 & Lumpkins et al. (2007) & $0.49,0.59,0.69,0.79,0.89$ & Female & Cobb & $8-19$ & 0.67 & Broken line models & 0.75 & 0.74 \\
\hline 67 & Lumpkins et al. (2007) & $0.53,0.63,0.73,0.83,0.93$ & Male & Cobb & $8-19$ & 0.67 & Broken line models & 0.64 & 0.63 \\
\hline 68 & Lumpkins et al. (2007) & $0.53,0.63,0.73,0.83,0.93$ & Female & Cobb & $8-19$ & 0.61 & Broken line models & 0.65 & 0.64 \\
\hline 71 & $\begin{array}{l}\text { Fatufe and Rodehutscord. } \\
\text { (2005) }\end{array}$ & $\begin{array}{l}0.33,0.38,0.43,0.48,0.53 \\
0.63,0.73,0.93\end{array}$ & Male & Ross & $8-21$ & 0.59 & Exponential model & 0.64 & 0.66 \\
\hline 72 & $\begin{array}{l}\text { Fatufe and Rodehutscord. } \\
\text { (2005) }\end{array}$ & $\begin{array}{l}0.34,0.39,0.44,0.49,0.54 \\
0.64,0.74,0.94\end{array}$ & Male & Ross & $8-21$ & 0.61 & Exponential model & 0.64 & 0.66 \\
\hline 82 & Chamruspollert et al. (2004) & $\begin{array}{l}0.70,0.75,0.80,0.85,0.90 \\
1.00\end{array}$ & $M+F$ & Ross & $7-21$ & 0.97 & Broken line models & 0.84 & 0.82 \\
\hline 83 & Chamruspollert et al. (2004) & $\begin{array}{l}0.70,0.75,0.80,0.85,0.90 \\
1.00\end{array}$ & $M+F$ & Ross & $7-21$ & 0.81 & Broken line models & 0.80 & 0.78 \\
\hline 84 & Chamruspollert et al. (2004) & $\begin{array}{l}0.70,0.75,0.80,0.85,0.90 \\
1.00\end{array}$ & $M+F$ & Ross & $7-21$ & 0.88 & Broken line models & 0.84 & 0.82 \\
\hline
\end{tabular}




\begin{tabular}{|c|c|c|c|c|c|c|c|c|c|}
\hline \multirow[t]{2}{*}{$\begin{array}{l}\text { Exp } \\
\text { No. }\end{array}$} & \multirow[t]{2}{*}{ Reference } & \multirow[t]{2}{*}{$\begin{array}{l}\text { AFD methionine +cysteine } \\
\text { concentration in the diet }(\%)\end{array}$} & \multirow[t]{2}{*}{ Gender } & \multirow[t]{2}{*}{ Strain } & \multirow{2}{*}{$\begin{array}{l}\text { Age } \\
\text { of } \\
\text { birds }\end{array}$} & \multirow{2}{*}{$\begin{array}{l}\text { Published } \\
\text { Requirement } \\
\text { (\%) }\end{array}$} & \multirow[t]{2}{*}{$\begin{array}{l}\text { Models used by } \\
\text { the reference }\end{array}$} & \multicolumn{2}{|c|}{$\begin{array}{l}\text { Re-calculated requirement using } \\
\text { exponential models (\%) }\end{array}$} \\
\hline & & & & & & & & $\begin{array}{l}\text { AFD } \\
\text { methionine+cysteine } \\
\text { content for BWG }\end{array}$ & $\begin{array}{l}\text { SID } \\
\text { methionine+cysteine } \\
\text { content for BWG }\end{array}$ \\
\hline 131 & Albino et al. (1999) & $\begin{array}{l}0.58,0.64,0.70,0.76,0.82 \\
0.88\end{array}$ & Male & Hubbard & $4-24$ & 0.88 & Quadratic Model & 0.72 & 0.70 \\
\hline 132 & Albino et al. (1999) & $\begin{array}{l}0.58,0.64,0.70,0.76,0.82 \\
0.88\end{array}$ & Female & Hubbard & $1-21$ & 0.89 & Quadratic Model & 0.78 & 0.77 \\
\hline 133 & Albino et al. (1999) & $\begin{array}{l}0.58,0.64,0.70,0.76,0.82 \\
0.88\end{array}$ & Male & Ross & $1-21$ & 0.89 & Quadratic Model & 0.78 & 0.77 \\
\hline 134 & Albino et al. (1999) & $\begin{array}{l}0.58,0.64,0.70,0.76,0.82 \\
0.88\end{array}$ & Female & Ross & $1-21$ & 0.86 & Quadratic Model & 0.68 & 0.67 \\
\hline 142 & Baker et al. (1996) & $\begin{array}{l}0.40,0.46,0.52,0.58,0.64 \\
0.70\end{array}$ & Male & $\begin{array}{l}\text { Ross }+ \\
\text { Hubbard }\end{array}$ & $21-42$ & 0.64 & Quadratic Model & 0.63 & 0.66 \\
\hline
\end{tabular}


Appendix 4 Experiments for which the requirement on the AFD and SID methionine+cysteine concentration for FCR was estimated according to equation 2 and that also met the criteria for the overall regression to estimate relationship of the AFD and SID methionine+cysteine requirement for FCR with age

\begin{tabular}{|c|c|c|c|c|c|c|c|c|c|}
\hline \multirow[t]{2}{*}{$\begin{array}{l}\text { Exp } \\
\text { No. }\end{array}$} & \multirow[t]{2}{*}{ Reference } & \multirow[t]{2}{*}{$\begin{array}{l}\text { SI D methionine+cysteine } \\
\text { concentration in the diet } \\
(\%)\end{array}$} & \multirow[t]{2}{*}{ Gender } & \multirow[t]{2}{*}{ Strain } & \multirow[t]{2}{*}{$\begin{array}{l}\text { Age } \\
\text { of } \\
\text { birds }\end{array}$} & \multirow[t]{2}{*}{$\begin{array}{l}\text { Published } \\
\text { Requirement } \\
(\%)\end{array}$} & \multirow[t]{2}{*}{$\begin{array}{l}\text { Models used by } \\
\text { the reference }\end{array}$} & \multicolumn{2}{|c|}{$\begin{array}{l}\text { Re-calculated requirement using } \\
\text { exponential models }(\%)\end{array}$} \\
\hline & & & & & & & & $\begin{array}{l}\text { AFD } \\
\text { methionine+cysteine } \\
\text { content for FCR }\end{array}$ & $\begin{array}{l}\text { SID } \\
\text { methionine+cysteine } \\
\text { content for FCR }\end{array}$ \\
\hline 32 & Chamruspollert et al. (2002) & $0.61,0.69,0.76,0.84,0.91$ & Female & Ross & $7-14$ & 0.89 & Broken line models & 0.71 & 0.70 \\
\hline 51 & Mack et al. (1999) & $\begin{array}{l}0.52,0.58,0.64,0.70,0.76 \\
0.82\end{array}$ & Male & Ross & $\begin{array}{l}20- \\
40\end{array}$ & 0.79 & Exponential model & 0.81 & 0.83 \\
\hline 65 & Lumpkins et al. (2007) & $0.53,0.63,0.73,0.83,0.93$ & Male & Cobb & 8-19 & 0.79 & Broken line models & 0.66 & 0.65 \\
\hline 66 & Lumpkins et al. (2007) & $0.53,0.63,0.73,0.83,0.93$ & Female & Cobb & 8-19 & 0.67 & Broken line models & 0.72 & 0.71 \\
\hline 71 & Fatufe and Rodehutscord. (2005) & $\begin{array}{l}0.42,0.47,0.52,0.57,0.62 \\
0.72,0.82,1.02\end{array}$ & Male & Ross & $8-21$ & 0.59 & Exponential model & 0.54 & 0.55 \\
\hline 72 & Fatufe and Rodehutscord. (2005) & $\begin{array}{l}0.42,0.47,0.52,0.57,0.62 \\
0.72,0.82,1.02\end{array}$ & Male & Ross & $8-21$ & 0.61 & Exponential model & 0.52 & 0.53 \\
\hline 81 & Chamruspollert et al. (2004) & $\begin{array}{l}0.68,0.73,0.78,0.83,0.88 \\
0.98\end{array}$ & $M+F$ & Ross & $7-21$ & 0.85 & Broken line models & 0.92 & 0.90 \\
\hline 83 & Chamruspollert et al. (2004) & $\begin{array}{l}0.68,0.73,0.78,0.83,0.88 \\
0.98\end{array}$ & $M+F$ & Ross & $7-21$ & 0.80 & Broken line models & 0.82 & 0.80 \\
\hline 84 & Chamruspollert et al. (2004) & $\begin{array}{l}0.68,0.73,0.78,0.83,0.88 \\
0.98\end{array}$ & $M+F$ & Ross & $7-21$ & 0.86 & Broken line models & 0.86 & 0.84 \\
\hline 131 & Albino et al. (1999) & $\begin{array}{l}0.57,0.63,0.69,0.75,0.81 \\
0.87\end{array}$ & Male & Hubbard & $4-24$ & 0.88 & Quadratic Model & 0.71 & 0.70 \\
\hline 133 & Albino et al. (1999) & $\begin{array}{l}0.57,0.63,0.69,0.75,0.81 \\
0.87\end{array}$ & Male & Ross & $1-21$ & 0.89 & Quadratic Model & 0.68 & 0.66 \\
\hline
\end{tabular}




\begin{tabular}{|c|c|c|c|c|c|c|c|c|c|}
\hline \multirow[t]{2}{*}{$\begin{array}{l}\text { Exp } \\
\text { No. }\end{array}$} & \multirow[t]{2}{*}{ Reference } & \multirow[t]{2}{*}{$\begin{array}{l}\text { SI D methionine+cysteine } \\
\text { concentration in the diet } \\
(\%)\end{array}$} & \multirow[t]{2}{*}{ Gender } & \multirow[t]{2}{*}{ Strain } & \multirow[t]{2}{*}{$\begin{array}{l}\text { Age } \\
\text { of } \\
\text { birds }\end{array}$} & \multirow[t]{2}{*}{$\begin{array}{l}\text { Published } \\
\text { Requirement } \\
(\%)\end{array}$} & \multirow[t]{2}{*}{$\begin{array}{l}\text { Models used by } \\
\text { the reference }\end{array}$} & \multicolumn{2}{|c|}{$\begin{array}{l}\text { Re-calculated requirement using } \\
\text { exponential models (\% ) }\end{array}$} \\
\hline & & & & & & & & $\begin{array}{l}\text { AFD } \\
\text { methionine+cysteine } \\
\text { content for FCR }\end{array}$ & $\begin{array}{l}\text { SID } \\
\text { methionine+cysteine } \\
\text { content for FCR }\end{array}$ \\
\hline 134 & Albino et al. (1999) & $\begin{array}{l}0.57,0.63,0.69,0.75,0.81 \\
0.87\end{array}$ & Female & Ross & $1-21$ & 0.86 & Quadratic Model & 0.65 & 0.64 \\
\hline 142 & Baker et al. (1996) & $\begin{array}{l}0.43,0.49,0.55,0.61,0.67 \\
0.73\end{array}$ & Male & $\begin{array}{l}\text { Ross }+ \\
\text { Hubbard }\end{array}$ & $\begin{array}{l}21- \\
42\end{array}$ & 0.64 & Quadratic Model & 0.71 & 0.74 \\
\hline
\end{tabular}


Appendix 5 Experiments for which the requirement on the AFD and SID valine concentration for BWG was estimated according to equation 2 and that also met the criteria for the overall regression to estimate relationship of the AFD and SID valine requirement for BWG with age

\begin{tabular}{|c|c|c|c|c|c|c|c|c|c|}
\hline \multirow[t]{2}{*}{$\begin{array}{l}\text { Exp } \\
\text { No. }\end{array}$} & \multirow[t]{2}{*}{ Reference } & \multirow[t]{2}{*}{$\begin{array}{l}\text { AFD valine concentration in } \\
\text { the diet }(\%)\end{array}$} & \multirow[t]{2}{*}{ Gender } & \multirow[t]{2}{*}{ Strain } & \multirow[t]{2}{*}{$\begin{array}{l}\text { Age of } \\
\text { birds }\end{array}$} & \multirow{2}{*}{$\begin{array}{l}\text { Published } \\
\text { Requirement } \\
(\%)\end{array}$} & \multirow{2}{*}{$\begin{array}{l}\text { Models used } \\
\text { by the } \\
\text { reference }\end{array}$} & \multicolumn{2}{|c|}{$\begin{array}{l}\text { Re-calculated requirement using } \\
\text { exponential models }(\%)\end{array}$} \\
\hline & & & & & & & & $\begin{array}{l}\text { AFD valine content } \\
\text { for BWG }\end{array}$ & $\begin{array}{l}\text { SID valine } \\
\text { content for BWG }\end{array}$ \\
\hline 41 & Corzo et al. 2008 & $0.64,0.72,0.80,0.88,0.96,1.04$ & Male & Ross 308 & $1-14$ & 0.91 & Quadratic & 0.92 & 0.90 \\
\hline 42 & Corzo et al. 2008 & $0.62,0.69,0.76,0.83,0.90,0.97$ & Male & Ross 308 & $14-28$ & 0.86 & Quadratic & 0.88 & 0.87 \\
\hline 43 & Corzo et al. 2008 & $0.54,0.61,0.68,0.75,0.82,0.89$ & Male & Ross 308 & $28-42$ & 0.77 & Quadratic & 0.74 & 0.73 \\
\hline 71 & Mack et al. 1999 & $0.56,0.62,0.67,0.73,0.78,0.83$ & Male & ISA 220 & $20-40$ & 0.76 & Quadratic & 0.73 & 0.75 \\
\hline
\end{tabular}


Appendix 6 Experiments for which the requirement on the AFD and SID valine concentration for FCR was estimated according to equation 2 and that also met the criteria for the overall regression to estimate relationship of the AFD and SID valine requirement for FCR with age

\begin{tabular}{|c|c|c|c|c|c|c|c|c|c|}
\hline \multirow[t]{2}{*}{$\begin{array}{l}\text { Exp } \\
\text { No. }\end{array}$} & \multirow[t]{2}{*}{ Reference } & \multirow[t]{2}{*}{$\begin{array}{l}\text { SI D valine concentration in the } \\
\text { diet }(\%)\end{array}$} & \multirow[t]{2}{*}{ Gender } & \multirow[t]{2}{*}{ Strain } & \multirow[t]{2}{*}{$\begin{array}{l}\text { Age of } \\
\text { birds }\end{array}$} & \multirow{2}{*}{$\begin{array}{l}\text { Published } \\
\text { Requirement } \\
(\%)\end{array}$} & \multirow{2}{*}{$\begin{array}{l}\text { Models used } \\
\text { by the } \\
\text { reference }\end{array}$} & \multicolumn{2}{|c|}{$\begin{array}{l}\text { Re-calculated requirement using } \\
\text { exponential models }(\%)\end{array}$} \\
\hline & & & & & & & & $\begin{array}{l}\text { AFD valine content } \\
\text { for FCR }\end{array}$ & $\begin{array}{l}\text { SID valine } \\
\text { content for FCR }\end{array}$ \\
\hline 41 & Corzo et al. 2008 & $0.64,0.72,0.80,0.88,0.96,1.04$ & Male & Ross 308 & $1-14$ & 0.91 & Quadratic & 0.96 & 0.96 \\
\hline 42 & Corzo et al. 2008 & $0.63,0.70,0.77,0.84,0.91,0.98$ & Male & Ross 308 & $14-28$ & 0.86 & Quadratic & 0.76 & 0.76 \\
\hline 43 & Corzo et al. 2008 & $0.55,0.62,0.69,0.76,0.83,0.90$ & Male & Ross 308 & $28-42$ & 0.77 & Quadratic & 0.66 & 0.67 \\
\hline 71 & Mack et al. 1999 & $0.59,0.64,0.70,0.75,0.81,0.86$ & Male & ISA 220 & $20-40$ & 0.76 & Quadratic & 0.69 & 0.73 \\
\hline
\end{tabular}


Appendix 7 Experiments for which the requirement on the AFD and SID arginine concentration for BWG was estimated according to equation 2 and that also met the criteria for the overall regression to estimate relationship of the AFD and SID arginine requirement for BWG with age

\begin{tabular}{|c|c|c|c|c|c|c|c|c|c|}
\hline \multirow[t]{2}{*}{$\begin{array}{l}\text { Exp } \\
\text { No. }\end{array}$} & \multirow[t]{2}{*}{ Reference } & \multirow{2}{*}{$\begin{array}{l}\text { AFD arginine } \\
\text { concentration in the diet } \\
(\%)\end{array}$} & \multirow[t]{2}{*}{ Gender } & \multirow[t]{2}{*}{ Strain } & \multirow{2}{*}{$\begin{array}{l}\text { Age } \\
\text { of } \\
\text { birds }\end{array}$} & \multirow{2}{*}{$\begin{array}{l}\text { Published } \\
\text { Requirement } \\
(\%)\end{array}$} & \multirow{2}{*}{$\begin{array}{l}\text { Models } \\
\text { used by } \\
\text { the } \\
\text { reference }\end{array}$} & \multicolumn{2}{|c|}{$\begin{array}{l}\text { Re-calculated requirement using } \\
\text { exponential models }(\%)\end{array}$} \\
\hline & & & & & & & & $\begin{array}{l}\text { AFD arginine } \\
\text { content for BWG }\end{array}$ & $\begin{array}{l}\text { SID arginine } \\
\text { content for } \\
\text { BWG }\end{array}$ \\
\hline 111 & Labadan et al. 2001 & $\begin{array}{l}0.88,0.96,1.04,1.12 \\
1.20,1.28,1.36\end{array}$ & Male & $\begin{array}{l}\text { Ross } x \\
\text { Avian }\end{array}$ & $0-14$ & 1.24 & broken-line & 1.33 & 1.32 \\
\hline
\end{tabular}


Appendix 8 Experiments for which the requirement on the AFD and SID arginine concentration for FCR was estimated according to equation 2 and that also met the criteria for the overall regression to estimate relationship of the AFD and SID arginine requirement for FCR with age

\begin{tabular}{|c|c|c|c|c|c|c|c|c|c|}
\hline \multirow[t]{2}{*}{$\begin{array}{l}\operatorname{Exp} \\
\text { No. }\end{array}$} & \multirow[t]{2}{*}{ Reference } & \multirow{2}{*}{$\begin{array}{l}\text { SI D arginine } \\
\text { concentration in the diet } \\
(\%)\end{array}$} & \multirow[t]{2}{*}{ Gender } & \multirow[t]{2}{*}{ Strain } & \multirow{2}{*}{$\begin{array}{l}\text { Age } \\
\text { of } \\
\text { birds }\end{array}$} & \multirow{2}{*}{$\begin{array}{l}\text { Published } \\
\text { Requirement } \\
(\%)\end{array}$} & \multirow{2}{*}{$\begin{array}{l}\text { Models } \\
\text { used by } \\
\text { the } \\
\text { reference }\end{array}$} & \multicolumn{2}{|c|}{$\begin{array}{l}\text { Re-calculated requirement using } \\
\text { exponential models ( } \% \text { ) }\end{array}$} \\
\hline & & & & & & & & $\begin{array}{l}\text { AFD arginine } \\
\text { content for FCR }\end{array}$ & $\begin{array}{l}\text { SID arginine } \\
\text { content for FCR }\end{array}$ \\
\hline 82 & $\begin{array}{l}\text { Chamruspollert et al. } \\
2004\end{array}$ & $\begin{array}{l}0.76,0.86,0.96,1.06 \\
1.16,1.26\end{array}$ & Male & Ross & $7-21$ & 1.15 & broken-line & 1.09 & 1.00 \\
\hline 111 & Labadan et al. 2001 & $\begin{array}{l}0.87,0.95,1.03,1.11 \\
1.19,1.27,1.35\end{array}$ & Male & $\begin{array}{l}\text { Ross } \mathrm{x} \\
\text { Avian }\end{array}$ & $0-14$ & 1.24 & broken-line & 1.37 & 1.35 \\
\hline 112 & Labadan et al. 2001 & $\begin{array}{l}0.79,0.87,0.95,1.03 \\
1.11,1.19\end{array}$ & Male & $\begin{array}{l}\text { Ross } x \\
\text { Avian }\end{array}$ & $\begin{array}{l}15- \\
28\end{array}$ & $1.05^{*}$ & broken-line & 1.18 & 1.09 \\
\hline
\end{tabular}


Appendix 9 Experiments for which the requirement on the AFD and SID isoleucine concentration for BWG was estimated according to equation 2 and that also met the criteria for the overall regression to estimate relationship of the AFD and SID isoleucine requirement for BWG with age

\begin{tabular}{|c|c|c|c|c|c|c|c|c|c|}
\hline \multirow[t]{2}{*}{$\begin{array}{l}\text { Exp } \\
\text { No. }\end{array}$} & \multirow[t]{2}{*}{ Reference } & \multirow[t]{2}{*}{$\begin{array}{l}\text { AFD isoleucine concentration } \\
\text { in the diet }(\%)\end{array}$} & \multirow[t]{2}{*}{ Gender } & \multirow[t]{2}{*}{ Strain } & \multirow[t]{2}{*}{$\begin{array}{l}\text { Age of } \\
\text { birds }\end{array}$} & \multirow{2}{*}{$\begin{array}{l}\text { Published } \\
\text { Requirement } \\
(\%)\end{array}$} & \multirow{2}{*}{$\begin{array}{l}\text { Models used } \\
\text { by the } \\
\text { reference }\end{array}$} & \multicolumn{2}{|c|}{$\begin{array}{l}\text { Re-calculated requirement } \\
\text { using exponential models (\%) }\end{array}$} \\
\hline & & & & & & & & $\begin{array}{l}\text { AFD isoleucine } \\
\text { content for } \\
\text { BWG }\end{array}$ & $\begin{array}{l}\text { SID isoleucine } \\
\text { content for } \\
\text { BWG }\end{array}$ \\
\hline 11 & $\begin{array}{l}\text { Tavernari et al. } \\
2012\end{array}$ & $\begin{array}{l}0.58,0.62,0.65,0.69,0.72 \\
0.76\end{array}$ & Male & $\begin{array}{l}\text { Cobb } \\
500\end{array}$ & $7-21$ & 0.64 & Quadratic & 0.61 & 0.56 \\
\hline 12 & $\begin{array}{l}\text { Tavernari et al. } \\
2012\end{array}$ & $\begin{array}{l}0.52,0.56,0.59,0.63,0.67 \\
0.70\end{array}$ & Male & $\begin{array}{l}\text { Cobb } \\
500\end{array}$ & $30-43$ & 0.61 & Quadratic & 0.61 & 0.56 \\
\hline
\end{tabular}


Appendix 10 Experiments for which the requirement on the AFD and SID isoleucine concentration for FCR was estimated according to equation 2 and that also met the criteria for the overall regression to estimate relationship of the AFD and SID isoleucine requirement for FCR with age

\begin{tabular}{|c|c|c|c|c|c|c|c|c|c|}
\hline \multirow[t]{2}{*}{$\begin{array}{l}\text { Exp } \\
\text { No. }\end{array}$} & \multirow[t]{2}{*}{ Reference } & \multirow[t]{2}{*}{$\begin{array}{l}\text { SID isoleucine concentration in } \\
\text { the diet }(\%)\end{array}$} & \multirow[t]{2}{*}{ Gender } & \multirow[t]{2}{*}{ Strain } & \multirow[t]{2}{*}{$\begin{array}{l}\text { Age of } \\
\text { birds }\end{array}$} & \multirow{2}{*}{$\begin{array}{l}\text { Published } \\
\text { Requirement } \\
(\%)\end{array}$} & \multirow{2}{*}{$\begin{array}{l}\text { Models used } \\
\text { by the } \\
\text { reference }\end{array}$} & \multicolumn{2}{|c|}{$\begin{array}{l}\text { Re-calculated requirement using } \\
\text { exponential models ( } \%)\end{array}$} \\
\hline & & & & & & & & $\begin{array}{l}\text { AFD isoleucine } \\
\text { content for FCR }\end{array}$ & $\begin{array}{l}\text { SID isoleucine } \\
\text { content for } \\
\text { FCR }\end{array}$ \\
\hline 11 & Tavernari et al. 2012 & $0.53,0.57,0.60,0.64,0.67,0.71$ & Male & Cobb 500 & $7-21$ & 0.64 & Quadratic & 0.61 & 0.56 \\
\hline 51 & Mack et al. 1999 & $0.53,0.58,0.63,0.68,0.72,0.77$ & Male & ISA & $20-40$ & 0.69 & Exponential & 0.55 & 0.56 \\
\hline
\end{tabular}


Appendix 11 Experiments for which the requirement on the AFD and SID threonine concentration for BWG was estimated according to equation 2 and that also met the criteria for the overall regression to estimate the relationship of the AFD and SID threonine requirement for BWG with age

\begin{tabular}{|c|c|c|c|c|c|c|c|c|c|}
\hline \multirow[t]{2}{*}{$\begin{array}{l}\operatorname{Exp} \\
\text { No. }\end{array}$} & \multirow[t]{2}{*}{ Reference } & \multirow{2}{*}{$\begin{array}{l}\text { AFD threonine } \\
\text { concentration in the diet } \\
(\%)\end{array}$} & \multirow[t]{2}{*}{ Gender } & \multirow[t]{2}{*}{ Strain } & \multirow{2}{*}{$\begin{array}{l}\text { Age } \\
\text { of } \\
\text { birds }\end{array}$} & \multirow{2}{*}{$\begin{array}{l}\text { Published } \\
\text { Requirement } \\
(\%)\end{array}$} & \multirow{2}{*}{$\begin{array}{l}\text { Models used } \\
\text { by the } \\
\text { reference }\end{array}$} & \multicolumn{2}{|c|}{$\begin{array}{l}\text { Re-calculated requirement using } \\
\text { exponential models }(\%)\end{array}$} \\
\hline & & & & & & & & $\begin{array}{l}\text { AFD threonine } \\
\text { content for BWG }\end{array}$ & $\begin{array}{l}\text { SID threonine } \\
\text { content for BWG }\end{array}$ \\
\hline 23.1 & Corzo et al. 2007 & $\begin{array}{l}0.40,0.47,0.54,0.61,0.68 \\
0.75\end{array}$ & Male & Ross 708 & $21-42$ & 0.74 & Quadratic & 0.63 & 0.65 \\
\hline 24.1 & $\begin{array}{l}\text { Ciftci and Ceylan } \\
2004\end{array}$ & $0.49,0.54,0.60,0.66$ & Male+Female & Ross PM3 & $1-22$ & 0.72 & Quadratic & 0.60 & 0.60 \\
\hline 24.3 & $\begin{array}{l}\text { Ciftci and Ceylan } \\
2004\end{array}$ & $0.47,0.53,0.59,0.65$ & Male+Female & Ross PM3 & $21-42$ & 0.64 & Quadratic & 0.57 & 0.58 \\
\hline 71.1 & Rosa et al. 2001 & $\begin{array}{l}0.50,0.54,0.58,0.62,0.66 \\
0.70\end{array}$ & Male & $\begin{array}{l}\text { Classic Arbor } \\
\text { Acres }\end{array}$ & $1-18$ & 0.69 & Quadratic & 0.62 & 0.64 \\
\hline 71.2 & Rosa et al. 2001 & $\begin{array}{l}0.50,0.54,0.58,0.62,0.66 \\
0.70\end{array}$ & Male & $\begin{array}{l}\text { High yield } \\
\text { broiler chicken }\end{array}$ & $1-18$ & 0.68 & Quadratic & 0.59 & 0.61 \\
\hline 71.3 & Rosa et al. 2001 & $\begin{array}{l}0.50,0.54,0.58,0.62,0.66 \\
0.70\end{array}$ & Male & $\begin{array}{l}\text { High yield } \\
\text { broiler chicken }\end{array}$ & $1-18$ & 0.71 & Quadratic & 0.65 & 0.67 \\
\hline 71.4 & Rosa et al. 2001 & $\begin{array}{l}0.50,0.54,0.58,0.62,0.66 \\
0.70\end{array}$ & Female & $\begin{array}{l}\text { High yield } \\
\text { broiler chicken }\end{array}$ & $1-18$ & 0.70 & Quadratic & 0.68 & 0.70 \\
\hline
\end{tabular}


Appendix 12 Experiments for which the requirement on the AFD and SID threonine concentration for FCR was estimated according to equation 2 and that also met the criteria for the overall regression to estimate the relationship of the AFD and SID threonine requirement for FCR with age

\begin{tabular}{|c|c|c|c|c|c|c|c|c|c|}
\hline \multirow[t]{2}{*}{$\begin{array}{l}\text { Exp } \\
\text { No. }\end{array}$} & \multirow[t]{2}{*}{ Reference } & \multirow[t]{2}{*}{$\begin{array}{l}\text { SI D threonine concentration in } \\
\text { the diet }(\%)\end{array}$} & \multirow[t]{2}{*}{ Gender } & \multirow[t]{2}{*}{ Strain } & \multirow{2}{*}{$\begin{array}{l}\text { Age } \\
\text { of } \\
\text { birds }\end{array}$} & \multirow{2}{*}{$\begin{array}{l}\text { Published } \\
\text { Requirement } \\
(\%)\end{array}$} & \multirow{2}{*}{$\begin{array}{l}\text { Models used } \\
\text { by the } \\
\text { reference }\end{array}$} & \multicolumn{2}{|c|}{$\begin{array}{l}\text { Re-calculated requirement using } \\
\text { exponential models }(\%)\end{array}$} \\
\hline & & & & & & & & $\begin{array}{l}\text { AFD threonine } \\
\text { content for FCR }\end{array}$ & $\begin{array}{l}\text { SID threonine } \\
\text { content for FCR }\end{array}$ \\
\hline 5.1 & Mack et al. 1999 & $0.45,0.51,0.57,0.63,0.69,0.75$ & Male & ISA & $20-40$ & 0.59 & $\begin{array}{l}\text { Exponential } \\
\text { model }\end{array}$ & 0.54 & 0.55 \\
\hline 5.2 & Mack et al. 1999 & $0.45,0.51,0.57,0.63,0.69,0.75$ & Male & Ross 208 & $20-40$ & 0.60 & $\begin{array}{l}\text { Exponential } \\
\text { model }\end{array}$ & 0.57 & 0.58 \\
\hline 18.1 & Corzo et el. 2003 & $0.45,0.50,0.55,0.60,0.65,0.70$ & Female & Ross & $30-42$ & 0.69 & Quadratic & 0.54 & 0.55 \\
\hline 23.1 & Corzo et al. 2007 & $0.42,0.49,0.56,0.63,0.70,0.77$ & Male & Ross 708 & $21-42$ & 0.74 & Quadratic & 0.55 & 0.57 \\
\hline 23.2 & Corzo et al. 2007 & $0.42,0.49,0.56,0.63,0.70,0.77$ & Male & Ross 708 & $21-42$ & 0.73 & Quadratic & 0.58 & 0.60 \\
\hline 71.1 & Rosa et al. 2001 & $0.51,0.55,0.59,0.63,0.67,0.71$ & Male & Classic Arbor Acres & $1-18$ & 0.69 & Quadratic & 0.56 & 0.58 \\
\hline 71.2 & Rosa et al. 2001 & $0.51,0.55,0.59,0.63,0.67,0.71$ & Male & $\begin{array}{l}\text { High yield broiler } \\
\text { chicken }\end{array}$ & $1-18$ & 0.68 & Quadratic & 0.57 & 0.59 \\
\hline 71.3 & Rosa et al. 2001 & $0.51,0.55,0.59,0.63,0.67,0.71$ & Male & $\begin{array}{l}\text { High yield broiler } \\
\text { chicken }\end{array}$ & $1-18$ & 0.71 & Quadratic & 0.62 & 0.64 \\
\hline
\end{tabular}


Appendix 13 Experiments for which the requirement on the AFD and SID tryptophan concentration for BWG was estimated according to equation 2 and that also met the criteria for the overall regression to estimate the relationship of the AFD and SID tryptophan requirement for BWG with age

\begin{tabular}{|c|c|c|c|c|c|c|c|c|c|}
\hline \multirow[t]{2}{*}{$\begin{array}{l}\text { Exp } \\
\text { No. }\end{array}$} & \multirow[t]{2}{*}{ Reference } & \multirow[t]{2}{*}{$\begin{array}{l}\text { AFD tryptophan concentration in } \\
\text { the diet }(\%)\end{array}$} & \multirow[t]{2}{*}{ Gender } & \multirow[t]{2}{*}{ Strain } & \multirow{2}{*}{$\begin{array}{l}\text { Age } \\
\text { of } \\
\text { birds }\end{array}$} & \multirow{2}{*}{$\begin{array}{l}\text { Published } \\
\text { Requirement } \\
(\%)\end{array}$} & \multirow{2}{*}{$\begin{array}{l}\text { Models used } \\
\text { by the } \\
\text { reference }\end{array}$} & \multicolumn{2}{|c|}{$\begin{array}{l}\text { Re-calculated requirement using } \\
\text { exponential models }(\%)\end{array}$} \\
\hline & & & & & & & & $\begin{array}{l}\text { AFD tryptophan } \\
\text { content for BWG }\end{array}$ & $\begin{array}{l}\text { SID tryptophan } \\
\text { content for BWG }\end{array}$ \\
\hline 33 & Corzo et al. 2005b & $\begin{array}{l}0.113,0.133,0.153,0.173,0.193 \\
0.213,0.233\end{array}$ & Male & Ross 508 & $1-20$ & 0.21 & Quadratic & 0.23 & 0.23 \\
\hline 41 & Fatufe et al. 2005 & $\begin{array}{l}0.075,0.085,0.095,0.105,0.115 \\
0.135,0.155,0.195,0.235,0.275\end{array}$ & Male & Ross & $8-21$ & - & $\begin{array}{l}\text { Logistic } \\
\text { equation }\end{array}$ & 0.60 & 0.60 \\
\hline 53 & Shan et al. 2003 & $\begin{array}{l}0.114,0.139,0.164,0.189,0.214 \\
0.239\end{array}$ & Male & Cobb & $7-21$ & 0.15 & $\begin{array}{l}\text { Broken-line } \\
\text { linear }\end{array}$ & 0.25 & 0.24 \\
\hline 54 & Shan et al. 2003 & $\begin{array}{l}0.114,0.139,0.164,0.189,0.214 \\
0.239\end{array}$ & Male & Cobb & $7-21$ & 0.14 & $\begin{array}{l}\text { Broken-line } \\
\text { linear }\end{array}$ & 0.21 & 0.21 \\
\hline 61 & Rosa et al. 2001 & $\begin{array}{l}0.098,0.128,0.158,0.188,0.218 \\
0.248\end{array}$ & Male & $\begin{array}{l}\text { Arbor Acres } \\
\text { Classic }\end{array}$ & $1-18$ & 0.18 & $\begin{array}{l}\text { Broken-line } \\
\text { linear }\end{array}$ & 0.21 & 0.21 \\
\hline 62 & Rosa et al. 2001 & $\begin{array}{l}0.098,0.128,0.158,0.188,0.218 \\
0.248\end{array}$ & Male & $\begin{array}{l}\text { Arbor Acres } \\
\text { High Yield }\end{array}$ & $1-18$ & 0.17 & $\begin{array}{l}\text { Broken-line } \\
\text { linear }\end{array}$ & 0.19 & 0.19 \\
\hline 63 & Rosa et al. 2001 & $\begin{array}{l}0.098,0.128,0.158,0.188,0.218 \\
0.248\end{array}$ & Male & Ross 308 & $1-18$ & 0.17 & $\begin{array}{l}\text { Broken-line } \\
\text { linear }\end{array}$ & 0.18 & 0.18 \\
\hline 64 & Rosa et al. 2001 & $\begin{array}{l}0.098,0.128,0.158,0.188,0.218 \\
0.248\end{array}$ & Female & Ross 308 & $1-18$ & 0.17 & $\begin{array}{l}\text { Broken-line } \\
\text { linear }\end{array}$ & 0.18 & 0.18 \\
\hline 71 & Castro et al. 2000 & $0.134,0.149,0.164,0.179,0.194$ & Male & Hubbard & $1-21$ & 0.195 & Quadratic & 0.16 & 0.14 \\
\hline 81 & Mack et al. 1999 & $\begin{array}{l}0.130,0.140,0.150,0.160,0.170 \\
0.180\end{array}$ & Male & Ross 208 & $20-40$ & 0.21 & Exponential & 0.18 & 0.18 \\
\hline
\end{tabular}


Appendix 14 Experiments for which the requirement on the AFD and SID tryptophan concentration for FCR was estimated according to equation 2 and that also met the criteria for the overall regression to estimate the relationship of the AFD and SID tryptophan requirement for FCR with age

\begin{tabular}{|c|c|c|c|c|c|c|c|c|c|}
\hline \multirow[t]{2}{*}{$\begin{array}{l}\text { Exp } \\
\text { No. }\end{array}$} & \multirow[t]{2}{*}{ Reference } & \multirow[t]{2}{*}{$\begin{array}{l}\text { AFD tryptophan concentration } \\
\text { in the diet }(\%)\end{array}$} & \multirow[t]{2}{*}{ Gender } & \multirow[t]{2}{*}{ Strain } & \multirow{2}{*}{$\begin{array}{l}\text { Age } \\
\text { of } \\
\text { birds }\end{array}$} & \multirow{2}{*}{$\begin{array}{l}\text { Published } \\
\text { Requirement } \\
(\%)\end{array}$} & \multirow{2}{*}{$\begin{array}{l}\text { Models used } \\
\text { by the } \\
\text { reference }\end{array}$} & \multicolumn{2}{|c|}{$\begin{array}{l}\text { Re-calculated requirement using } \\
\text { exponential models }(\%)\end{array}$} \\
\hline & & & & & & & & $\begin{array}{l}\text { AFD tryptophan } \\
\text { content for FCR }\end{array}$ & $\begin{array}{l}\text { SID tryptophan } \\
\text { content for FCR }\end{array}$ \\
\hline 33 & Corzo et al. 2005b & $\begin{array}{l}0.113,0.133,0.153,0.173 \\
0.193,0.213,0.233\end{array}$ & Male & Ross 508 & $1-20$ & 0.21 & Quadratic & 0.21 & 0.21 \\
\hline 41 & Fatufe et al. 2005 & $\begin{array}{l}0.075,0.085,0.095,0.105 \\
0.115,0.135,0.155,0.195 \\
0.235,0.275\end{array}$ & Male & Ross & 8-21 & - & $\begin{array}{l}\text { Logistic } \\
\text { equation }\end{array}$ & 0.22 & 0.22 \\
\hline 53 & Shan et al. 2003 & $\begin{array}{l}0.114,0.139,0.164,0.189 \\
0.214,0.239\end{array}$ & Male & Cobb & $7-21$ & 0.15 & $\begin{array}{l}\text { Broken-line } \\
\text { linear }\end{array}$ & 0.20 & 0.20 \\
\hline 54 & Shan et al. 2003 & $\begin{array}{l}0.114,0.139,0.164,0.189 \\
0.214,0.239\end{array}$ & Male & Cobb & $7-21$ & 0.14 & $\begin{array}{l}\text { Broken-line } \\
\text { linear }\end{array}$ & 0.18 & 0.18 \\
\hline 61 & Rosa et al. 2001 & $\begin{array}{l}0.098,0.128,0.158,0.188 \\
0.218,0.248\end{array}$ & Male & $\begin{array}{l}\text { Arbor Acres } \\
\text { Classic }\end{array}$ & $1-18$ & 0.18 & $\begin{array}{l}\text { Broken-line } \\
\text { linear }\end{array}$ & 0.17 & 0.16 \\
\hline 62 & Rosa et al. 2001 & $\begin{array}{l}0.098,0.128,0.158,0.188 \\
0.218,0.248\end{array}$ & Male & $\begin{array}{l}\text { Arbor Acres } \\
\text { High Yield }\end{array}$ & $1-18$ & 0.17 & $\begin{array}{l}\text { Broken-line } \\
\text { linear }\end{array}$ & 0.18 & 0.18 \\
\hline 63 & Rosa et al. 2001 & $\begin{array}{l}0.098,0.128,0.158,0.188 \\
0.218,0.248\end{array}$ & Male & Ross 308 & $1-18$ & 0.17 & $\begin{array}{l}\text { Broken-line } \\
\text { linear }\end{array}$ & 0.17 & 0.17 \\
\hline 64 & Rosa et al. 2001 & $\begin{array}{l}0.098,0.128,0.158,0.188 \\
0.218,0.248\end{array}$ & Female & Ross 308 & $1-18$ & 0.17 & $\begin{array}{l}\text { Broken-line } \\
\text { linear }\end{array}$ & 0.19 & 0.19 \\
\hline 71 & Castro et al. 2000 & $\begin{array}{l}0.148,0.163,0.178,0.193 \\
0.208\end{array}$ & Male & Hubbard & $1-21$ & 0.195 & Quadratic & 0.21 & 0.19 \\
\hline
\end{tabular}



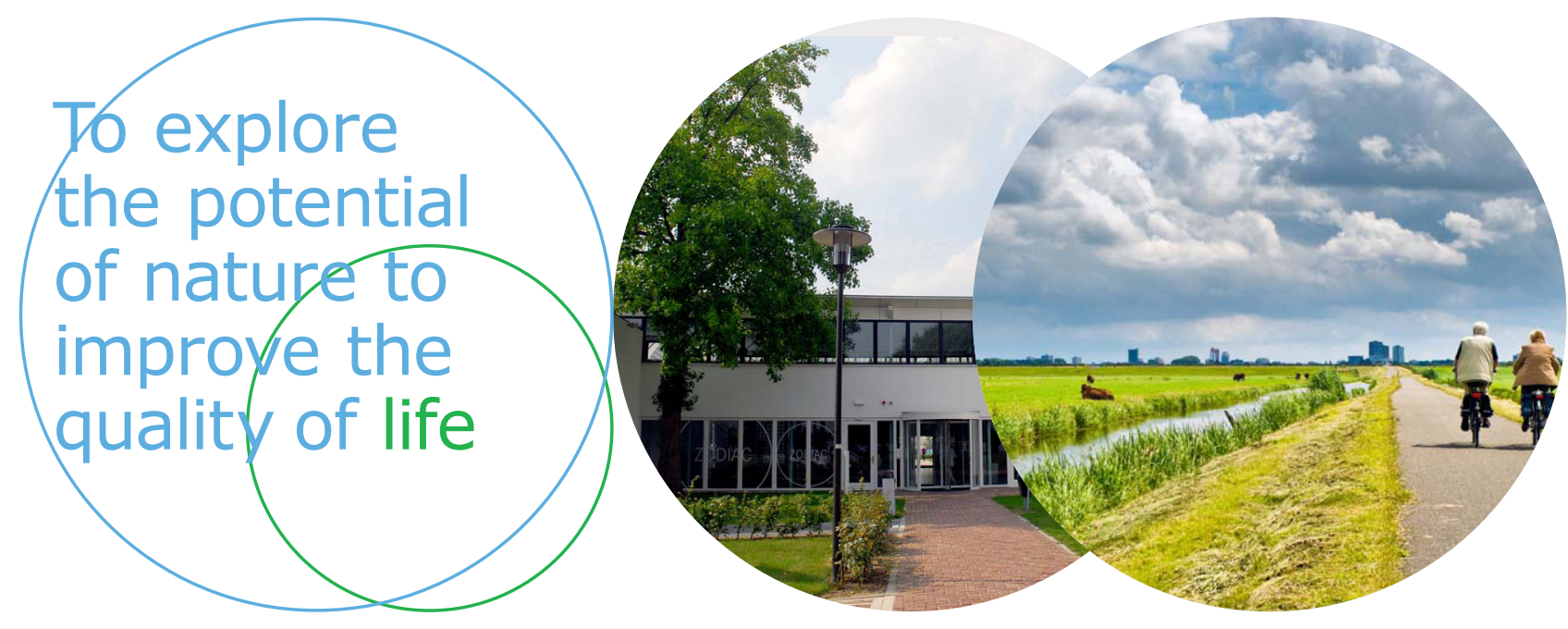

Wageningen UR Livestock Research

P.O. Box 338

$6700 \mathrm{AH}$ Wageningen

The Netherlands

T +31 (0)317483953

E info.livestockresearch@wur.nl

www.wageningenUR.nl/livestockresearch
Together with our clients, we integrate scientific know-how and practical experience to develop livestock concepts for the 21st century. With our expertise on innovative livestock systems, nutrition, welfare, genetics and environmental impact of livestock farming and our state-of-the art research facilities, such as Dairy Campus and Swine Innovation Centre Sterksel, we support our customers to find solutions for current and future challenges.

The mission of Wageningen UR (University \& Research centre) is 'To explore the potential of nature to improve the quality of life'. Within Wageningen UR, nine specialised research institutes of the DLO Foundation have joined forces with Wageningen University to help answer the most important questions in the domain of healthy food and living environment. With approximately 30 locations, 6,000 members of staff and 10,000 students, Wageningen UR is one of the leading organisations in its domain worldwide. The integral approach to problems and the cooperation between the various disciplines are at the heart of the unique Wageningen Approach. 